\title{
Floodplain vegetation of the River Murray in 1987-1988: an important pre-drought benchmark for subsequent studies
}

\author{
Peter Smith and Judy Smith \\ P \& J Smith Ecological Consultants, 44 Hawkins Parade, Blaxland, NSW 2774, AUSTRALIA, email: smitheco@ ozemail.com.au
}

\begin{abstract}
As part of a wider study of floodplain vegetation along the River Murray, we carried out a field survey in 1987-1988 involving collection of floristic and vegetation condition data from 335 sample plots (each $400 \mathrm{~m}^{2}$ in area), between Hume Dam and Lake Alexandrina (including the Edward-Wakool anabranch system). The floodplain vegetation is dominated by just two tree species, River Red Gum (Eucalyptus camaldulensis) and Black Box (Eucalyptus largiflorens), but the composition of the understorey shows much greater variation, both along the river and across the floodplain. A total of 499 plant species, subspecies and varieties were recorded from the survey plots, of which $316(63 \%)$ were native and $183(37 \%)$ were exotic. From analysis of the floristic data we identified 37 vegetation communities, not including the vegetation of permanent wetlands and cleared areas; 21 communities were distinguished in the River Red Gum zone, 12 communities in the Black Box zone, and 4 communities on rises within the floodplain. The main floristic division among the River Red Gum communities was between Riverine Plain/ Headwaters Zone communities of the upper Murray, and Mallee Zone communities of the lower Murray. Among the Black Box communities, the main floristic division was between inner floodplain communities and outer floodplain communities, with a further division between South Australian communities and New South Wales/Victorian communities. Major factors influencing the floristic patterns included flooding frequency/duration and soil salinity.
\end{abstract}

Eucalypt health declined steadily downstream and was poorest in the lower reaches of the river below the Darling Junction, where $60 \%$ of the trees were healthy, $18 \%$ unhealthy (at least $40 \%$ of the canopy dead) and $22 \%$ dead. By comparison, at the upper end of the river, above Tocumwal, $84 \%$ of the trees were healthy, $14 \%$ unhealthy and only $2 \%$ dead. Overall, the condition of Black Box trees (44\% unhealthy or dead) was worse than the condition of River Red Gum trees (29\% unhealthy or dead). Eucaypt regeneration was also poorest below the Darling Junction, with regenerants present in 77\% of plots upstream of the Darling but only 35\% of plots downstream. The findings of poor tree health and sparse regeneration below the Darling coincide with the most heavily regulated part of the Murray, where the reduction in flooding due to upstream storages and water extraction, mainly for irrigation, has been greatest. Black Box regeneration was much sparser overall than River Red Gum regeneration (regenerants present in 69\% of River Red Gum plots but only 29\% of Black Box plots). The poor condition of the Black Box trees, coupled with their poor regeneration, suggests that the long-term future of this species along the Murray, particularly below the Darling Junction, is tenuous, even though it is a dominant component of the vegetation.

The integrity of floodplain vegetation along the Murray has been severely compromised by weed invasion. Weeds were common throughout the survey area, but were most prevalent in the climatically wetter sections of the river, at both the downstream and upstream ends (below Mannum and above Tocumwal). The median number of exotic species per plot equalled or exceeded the number of native species in these sections of the river, whereas native species outnumbered exotic species in the other river sections. Communities of the River Red Gum zone and the rises were generally weedier than those of the Black Box zone. Exotic species strongly influenced the community classification. They were the dominant overstorey species in two communities (Salix species - willows) and outnumbered native 
species in the understorey of another eight communities. At the lower end of the river, below Mannum, the River Red Gums that originally fringed the river had been mostly replaced by dense thickets of the exotic Weeping Willow, Salix babylonica.

Other factors that have impacted on the floodplain vegetation at the plant community level have been river regulation and soil salinisation. Stabilization of water levels in the lower Murray by construction of a series of weirs and barrages has favoured the spread of some communities at the expense of others. The favoured communities, which are characterised by stands of Common Reed, Phragmites australis, along the water's edge, appear to be artefacts of river regulation. Salinisation has resulted in death of eucalypts and replacement of eucalypt communities by shrub communities dominated by samphires, Tecticornia species. The samphire community characteristic of the most saline sites is one of the most species-poor communities on the Murray floodplain.

Logging along the Murray in New South Wales and Victoria has resulted in extensive replacement of old growth River Red Gum forests and woodlands by more even-aged stands of straight young trees. Following the recent conversion of many areas of State Forest along the Murray in both New South Wales and Victoria to National Park or Regional Park, and thus the cessation of logging in these areas, they should now revert gradually to mature forest and woodland.

This study is the first to describe broad scale floristic patterns in the floodplain vegetation of the Murray covering most of the length of the river. It also provides data on the vegetation condition in the 1980s, and provides a benchmark of conditions before the prolonged Millenium Drought in south-eastern Australia from 1997 to 2010. More recent surveys of vegetation condition have reported a severe decline in tree health during the drought. The results from our 1987-88 survey are important because they show that the deteriorating condition of the vegetation was already evident in the 1980s and although exacerbated by the subsequent drought, it is not just a consequence of that drought. The results are consistent with the conclusion that the primary cause of the decline has been river regulation and water extraction for irrigation. The rate of deterioration has increased rapidly since the 1980s because of the drought. There has been some improvement since the breaking of the drought, but the poor condition of the River Murray floodplain vegetation, an Australian icon, remains a major conservation and management issue. The impacts of climate change higher temperatures and reduced rainfall - have compounded the problem and will continue to do so at an increasing rate. The results of the study support listing of the floodplain vegetation of the lower reaches of the river as a critically endangered ecological community.

Cunninghamia (2014) 14: 97-151

Doi 10.7751/cunninghamia.2014.14.007

\section{Introduction}

The River Murray and its tributaries form the largest river system in Australia, with a catchment, the Murray-Darling Basin, covering nearly one seventh of the continent. The Murray flows some $2530 \mathrm{~km}$ through New South Wales, Victoria and South Australia, from its source in the Great Dividing Range to its mouth on the Southern Ocean (Mackay and Eastburn 1990). Water flow in the Murray is low compared with rivers of similar catchment size on other continents, and it is highly variable (Young 2001). Over the last two centuries, its waters have become increasingly regulated, especially since the 1920s, largely to support irrigated agriculture (Close 1990, Maheshwari et al. 1995). The Murray system is now controlled by many dams and weirs, and water from the Snowy River has been diverted westward across the Great Dividing Range to augment the Murray flow. However, the economic and social benefits of this control and use of the Murray's waters have had major environmental costs through declining river health, including hydrological, geomorphological, salinity and water quality impacts, as well as impacts on fish, aquatic invertebrates, floodplain vegetation and wetland biota (Walker and Thoms 1993, Thoms et al. 2000, Kingsford 2000, Gippel and Blackham 2002, Gehrke et al. 2003, Davies et al. 2008, Jensen and Walker 2012).
Existing levels of water use are clearly unsustainable. In 2002 the Living Murray restoration program was established to facilitate recovery of water to improve environmental conditions at a series of icon sites along the river (MurrayDarling Basin Authority 2011). More recently, a Basin Plan has been adopted for integrated management of the waters of the Murray-Darling Basin (Commonwealth of Australia 2012). The intention of the Basin Plan is to optimise social, economic and environmental outcomes from use of the Basin water resources. The environmental objective is healthy and resilient ecosystems with rivers and creeks regularly connected to their floodplains and, ultimately, the ocean. However, the capacity of the Basin Plan to deliver a healthy working river system has been questioned (e.g. Cosier et al. 2012).

The River Murray Riparian Vegetation Study, undertaken between 1987 and 1989, was commissioned by the then Murray-Darling Basin Commission to provide baseline information on floodplain vegetation patterns and vegetation condition along the Murray (Margules and Partners et al. 1990, Smith and Smith 1990). The study results were provided as a report and as geographic information system mapping. While this information has been used, for example, by Benson et al. (2006) and Benson (2008) in their classification of New South Wales plant communities, it is not readily available. The present paper aims to disseminate the information more 
widely in the formal scientific record and describes the findings of the River Murray Riparian Vegetation Study in relation to floristic classification of the floodplain vegetation communities, which was the part of the study for which we were responsible.

Vegetation condition data were also collected during our field survey and are important because they document the condition of the floodplain vegetation in the 1980s, a period of relatively good rainfall before the 'Millennium Drought', a severe and prolonged drought in south-eastern Australia from 1997 to 2010 (Murphy and Timbal 2007, National Climate Centre 2010). A rapid decline in floodplain vegetation condition has been reported in more recent surveys carried out during the drought (Murray-Darlin Basin Commission 2003, Smith and Kenny 2005, Cunningham et al. 2009). The 1987-88 condition data that are analysed in this paper provide a benchmark to assess the subsequent impacts of the drought and to assess the impacts of river regulation and salinisation before the drought.

The floodplain vegetation of the Murray is an Australian icon, especially the characteristic tree, the River Red Gum, Eucalyptus camaldulensis. There have been many studies of ecological processes in this vegetation (e.g. Craig et al. 1991, Bren 1992, Thorburn and Walker 1994, Overton et al. 2006). However, descriptive studies of vegetation patterns on the floodplain have been fewer and have been limited in geographical extent (e.g. Chesterfield et al. 1984, Chesterfield 1986, Ashwell 1987, Roberts and Ludwig 1990) or have considered floodplain vegetation only as part of a broader vegetation survey (e.g. Frood 1983, Fox 1991, Scott 1992, Porteners 1993). The present study is still the only study that has described floristic patterns in the Murray floodplain vegetation over a wide geographical scale, covering most of the length of the Murray, including the Edward-Wakool anabranch system.

\section{Survey Area}

The survey area comprised the floodplains of the River Murray and its anabranches, including the Edward-Wakool river system, from below Hume Dam, downstream to the upper end of Lake Alexandrina (Fig. 1).

The Murray passes through three major geomorphic zones: the Headwaters Zone, Riverine Plain and Mallee Zone (Mackay and Eastburn 1990). The Headwaters Zone extends from the river's source near Mount Kosciuszko to about Corowa, corresponding to the tablelands and western slopes regions of the Great Dividing Range. The survey area included only the western end of the Headwaters Zone, from Hume Dam to Corowa. The Riverine Plain extends from Corowa to about Wakool Junction. This vast alluvial plain, formed under a different climate and hydrology from the present, has a characteristic anastomosing drainage and it is here that the Murray receives most of its major Victorian tributaries (Butler et al. 1973, Storrier and Kelly 1978). For the remainder of its course, the Murray flows through the Mallee Zone, which was formerly inundated by the sea and is characterised by sand dunes and highly saline groundwater (Bowler and Magee 1978, Storrier and Stannard 1980). Surface runoff after rain is insufficient to form a local stream system. The Murrumbidgee and Darling Rivers, the two major tributaries which join the Murray in the Mallee Zone, both come from better-watered regions.

These three broad zones can be further subdivided. In a survey of Murray wetlands, Pressey (1986) divided the floodplain between Hume Dam and Lake Alexandrina into eight sections based on differences in hydrology and geomorphology, but also corresponding to climatic differences (Fig. 1). Pressey's sections were used in the present study and are described below.

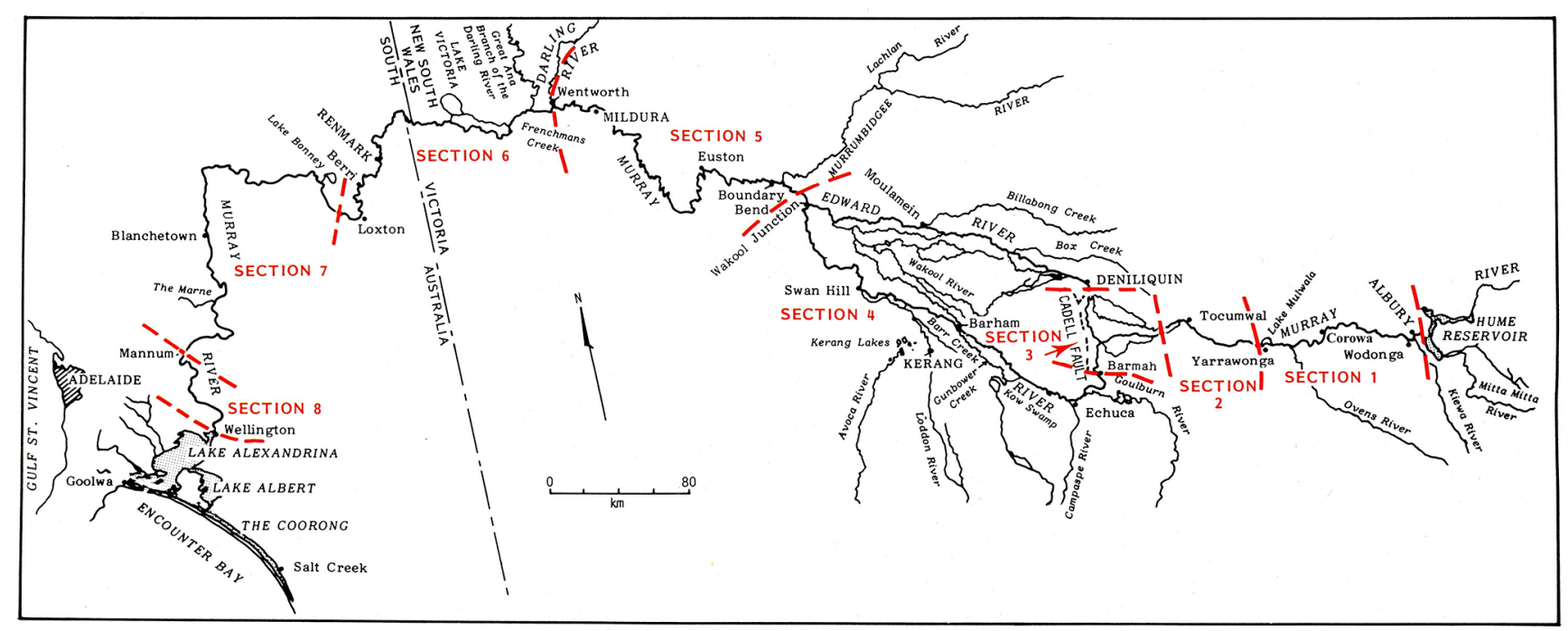

Fig. 1. Map of the River Murray showing the eight sections of the survey area. 


\section{Section 1}

Floodplain of the Murray from Hume Dam to Yarrawonga Weir. A transition area between the Headwaters Zone and the Riverine Plain. River length is $233 \mathrm{~km}$. The floodplain is relatively narrow, varying from 1.5 to $5 \mathrm{~km}$ wide, with a total floodplain area of $292 \mathrm{~km}^{2}$ (statistics from Pressey 1986). The climate is cooler and wetter than in the other river sections, corresponding to Nix and Kalma's (1982) climatic subregion B12a. Mean annual rainfall is 500-650 mm, distributed fairly evenly through the year (data from Bureau of Meteorology).

\section{Section 2}

Floodplain of the Murray from Yarrawonga Weir to the downstream end of Ulupna Island, below Tocumwal. Forms part of the Riverine Plain. River length is $124 \mathrm{~km}$, floodplain width is generally $2-3 \mathrm{~km}$, and floodplain area is $164 \mathrm{~km}^{2}$. Forms part of Nix and Kalma's (1982) climatic subregion B12b, with a generally warmer, drier climate than Section 1. Mean annual rainfall is $420-500 \mathrm{~mm}$.

\section{Section 3}

Floodplain of the Murray from Ulupna Island to Barmah, and floodplain of the Edward River from the offtake to $3 \mathrm{~km}$ upstream of the Lawson Siphon, near Deniliquin. Also includes the Tuppal-Bullatale anabranch system. Forms part of the Riverine Plain. River lengths are Murray $108 \mathrm{~km}$ and Edward $51 \mathrm{~km}$. Floodplain width varies from about $1 \mathrm{~km}$ at the upstream end to more than $25 \mathrm{~km}$ near the Edward offtake. Floodplain area is $1366 \mathrm{~km}^{2}$. The climate is similar to Section 2, forming part of Nix and Kalma's (1982) climatic subregion B12b. Mean annual rainfall is $400-420 \mathrm{~mm}$. The broad triangular floodplain and complex channel system are a consequence of the Cadell Fault, which runs roughly from Echuca to Deniliquin (Fig. 1). The uplifting of the Cadell Fault some 25000 years ago blocked the westward passage of the Murray and brought about a division into the Edward flowing north of the fault and the present Murray flowing south (Bowler 1978).

\section{Section 4}

Floodplain of the Murray from Barmah to $11 \mathrm{~km}$ downstream of Wakool Junction, and floodplain of the Edward River below Deniliquin. Includes the extensive network of anabranches enclosed by the Murray and Edward Rivers, the largest of which are Wakool River, Niemur River, Colligen Creek, Yarrein Creek and Merran Creek. Forms part of the Riverine Plain. River lengths are Murray $487 \mathrm{~km}$ and Edward $356 \mathrm{~km}$. The floodplain of the Murray varies in width from about 1 $\mathrm{km}$ near Echuca to about $20 \mathrm{~km}$ near Cohuna. The floodplain of the Edward is generally less than $1 \mathrm{~km}$ wide, except in the Werai Forest area, where the combined floodplain of the Edward and two of its anabranches is more than $10 \mathrm{~km}$ wide. Several anabranches, in particular the Wakool River, have larger floodplains than the Edward. Total floodplain area is $3482 \mathrm{~km}^{2}$. Section 4 lies within Nix and Kalma's (1982) climatic subregion B11a, which has higher temperatures, greater solar radiation and, in particular, lower rainfall than the B12 classification of Sections 1 to 3. Mean annual rainfall is $300-400 \mathrm{~mm}$.

\section{Section 5}

Floodplain of the Murray from $11 \mathrm{~km}$ downstream of Wakool Junction to the Darling Junction. The Murrumbidgee River joins the Murray within this section. Forms part of the Mallee Zone. River length is $448 \mathrm{~km}$. The floodplain is broad, generally 5-12 km wide, but narrowing at Mildura and Wentworth to $1-3 \mathrm{~km}$, with a total floodplain area of $1568 \mathrm{~km}^{2}$. The climate is similar to Section 4, forming part of Nix and Kalma's (1982) climatic subregion B11a. Mean annual rainfall is $250-300 \mathrm{~mm}$.

\section{Section 6}

Floodplain of the Murray from the Darling Junction to $22 \mathrm{~km}$ downstream of Loxton. Forms part of the Mallee Zone. River length is $358 \mathrm{~km}$, the floodplain is broad, generally $5-10 \mathrm{~km}$ wide, and the total floodplain area is $1515 \mathrm{~km}^{2}$. The climate is hot and dry, corresponding to Nix and Kalma's (1982) climatic subregion B11b. Mean annual rainfall is around $250 \mathrm{~mm}$.

\section{Section 7}

Floodplain of the Murray from $22 \mathrm{~km}$ downstream of Loxton to Mannum. Forms part of the Mallee Zone. River length is $316 \mathrm{~km}$. The river flows through a narrow valley, 30-40 m deep, and the floodplain is generally less than $2 \mathrm{~km}$ wide, with a total floodplain area of $416 \mathrm{~km}^{2}$. Within Section 7 there is a transition from Nix and Kalma's (1982) climatic subregion $\mathrm{B} 11 \mathrm{~b}$ to subregion B11c, which is cooler, wetter and has a more pronounced rainfall seasonality, higher in winter and lower in summer. Mean annual rainfall is $200-300 \mathrm{~mm}$.

\section{Section 8}

Floodplain of the Murray from Mannum to $2 \mathrm{~km}$ downstream of Wellington, at the head of Lake Alexandrina. Forms part of the Mallee Zone. River length is $76 \mathrm{~km}$, the floodplain is generally less than $2 \mathrm{~km}$ wide, with a total floodplain area of $105 \mathrm{~km}^{2}$. Forms part of Nix and Kalma's (1982) climatic subregion B11c. Mean annual rainfall is $300-350 \mathrm{~mm}$.

\section{Methods}

\section{Field survey}

Sites were chosen subjectively to provide a geographically diverse coverage of each river section. 112 sites were visited on the floodplains of the Murray and Edward Rivers and their anabranches between Hume Dam and Lake Alexandrina, with 100 sites surveyed 8 September - 23 November 1987 , and 12 sites surveyed 26 January - 6 February 1988. 
Vegetation data were collected from one or more sample plots at each site, for a total of 335 plots. Sampling intensity was usually 1-6 plots per site, except for three sites of particular interest in South Australia (Lock 2, Dishers Creek Evaporation Basin and Murtho Forest), where 12-15 plots were sampled. The plots sampled different habitats or vegetation types at each site. Habitats across the floodplain were sampled, including rises within the floodplain above flood levels, but excluding inundated areas (permanent wetlands) and cleared areas. Time constraints did not allow sampling of all habitats at all sites (where this was attempted, for example, in the complex floodplain at Murtho Forest, 12 plots were needed). Usually only one plot was sampled per habitat per site, but three replicate plots were sampled per habitat in brief investigations of salt-affected vegetation at Dishers Creek Evaporation Basin, and vegetation under different flooding regimes upstream and downstream of Lock 2.

Each plot was $400 \mathrm{~m}^{2}$ in area, measuring either $20 \mathrm{~m} \mathrm{X} 20$ $\mathrm{m}$ or, in narrow, elongated habitats such as riverbanks, $40 \mathrm{~m}$ X $10 \mathrm{~m}$. Vegetation structure was recorded by estimating the average height and foliage cover of each vegetation layer. The vascular plant species growing within or overhanging the plot were identified and the cover/abundance of each species was recorded on a scale of 1 to $6(1=$ few plants, cover $<5 \%$; $2=$ many plants, cover $<5 \%$; $3=$ cover $5-24 \%$; $4=$ cover $25-49 \% ; 5=$ cover $50-74 \% ; 6=$ cover $75-100 \%$ ). Species identifications were updated in 2011 to take account of nomenclatural changes since the original survey. This included some re-examination of specimens collected during the survey.

The condition of the eucalypt trees was assessed by counting the number of trees in or overhanging the plot under three categories: healthy (less than $40 \%$ of the crown dead), unhealthy $(40 \%$ or more of the crown dead) or dead (not including stumps). Where necessary, additional trees adjacent to the plot were counted in order to sample at least 10 trees.

Regeneration of eucalypt species was assessed by counting the number of seedlings and saplings per plot in each of three classes: $<1 \mathrm{~m}$ tall, $1-4 \mathrm{~m}$ tall, and $>4 \mathrm{~m}$ tall. Coppice regeneration, seedlings under $5 \mathrm{~cm}$ high, and saplings with a diameter at breast height of $20 \mathrm{~cm}$ or more were not included in the counts. Regenerants included in the counts varied greatly in height, from $5 \mathrm{~cm}$ to about $16 \mathrm{~m}$.

An index of grazing intensity was calculated for each plot by randomly laying a $20 \mathrm{~m}$ tape across the plot and counting the number of grazing animal droppings that touched the tape. For species that produce droppings in clusters, each cluster was counted as a single dropping. Additional grazing species for which there was evidence within the plot but not along the tape, were included in the count with an arbitrary value of 0.5 droppings.

\section{Data analysis}

The 335 plots were classified into plant communities based on the species composition and abundance data. Some pairs or groups of species were not consistently distinguished in the plots and were thus combined for the analysis (Appendix 2). Because of the large size of the data set, the classification was carried out in two stages. An initial non-hierarchical classification was performed by composite clustering (Gauch 1980), using the computer program COMPCLUS (Gauch 1979). This clustered the plots into 78 groups. A hierarchical classification of the 78 groups was then carried out by twoway indicator species analysis (Gauch and Whittaker 1981), using the program TWINSPAN (Hill 1979a). Relationships among the 78 COMPCLUS groups were further examined by the ordination technique of detrended correspondence analysis (Hill and Gauch 1980), using the program DECORANA (Hill 1979b).

The COMPCLUS groups within each TWINSPAN grouping were assessed subjectively. They were retained in the final classification if they reflected an obvious vegetation difference, or combined if the difference was considered minor. A few plots appeared to have been misclassified and were reassigned subjectively to other groups. One unusual plot was excluded from the analysis.

Analyses were also carried out on some of the data using the SPC for Excel statistics package (BPI Consulting LLC, Cypress, Texas) and the PATN pattern analysis package (Blatant Fabrications Pty Ltd, Carlton, Tasmania).

\section{Vegetation mapping}

The floodplain vegetation of the survey area was mapped by other researchers independently but in parallel with the floristic survey (Margules and Partners et al. 1990). The mapping was done from air photos taken at various dates between 1965 and 1985. The map units were based on vegetation structure and condition rather than the floristic classification reported here. The results of the mapping are not included in this paper, but are available from the MurrayDarling Basin Authority as geographic information system layers.

\section{Results and Discussion}

\section{Vegetation zones}

The vegetation of the River Murray floodplain is dominated by just two tree species: River Red Gum Eucalyptus camaldulensis on the river banks and in low-lying areas, and Black Box Eucalyptus largiflorens in the less frequently flooded parts of the floodplain. There is a natural and wellknown division of the floodplain into a River Red Gum zone and a Black Box zone. Historically, River Red Gum communities have received more regular flooding (45 to 90 flood years per century) than Black Box communities (10 to 50 flood years per century) (Roberts 2004).

A third vegetation zone consists of the occasional rises within the floodplain. These rises are rarely if ever flooded and support non-floodplain vegetation similar to that found on similar soils outside the floodplain, namely woodlands of 


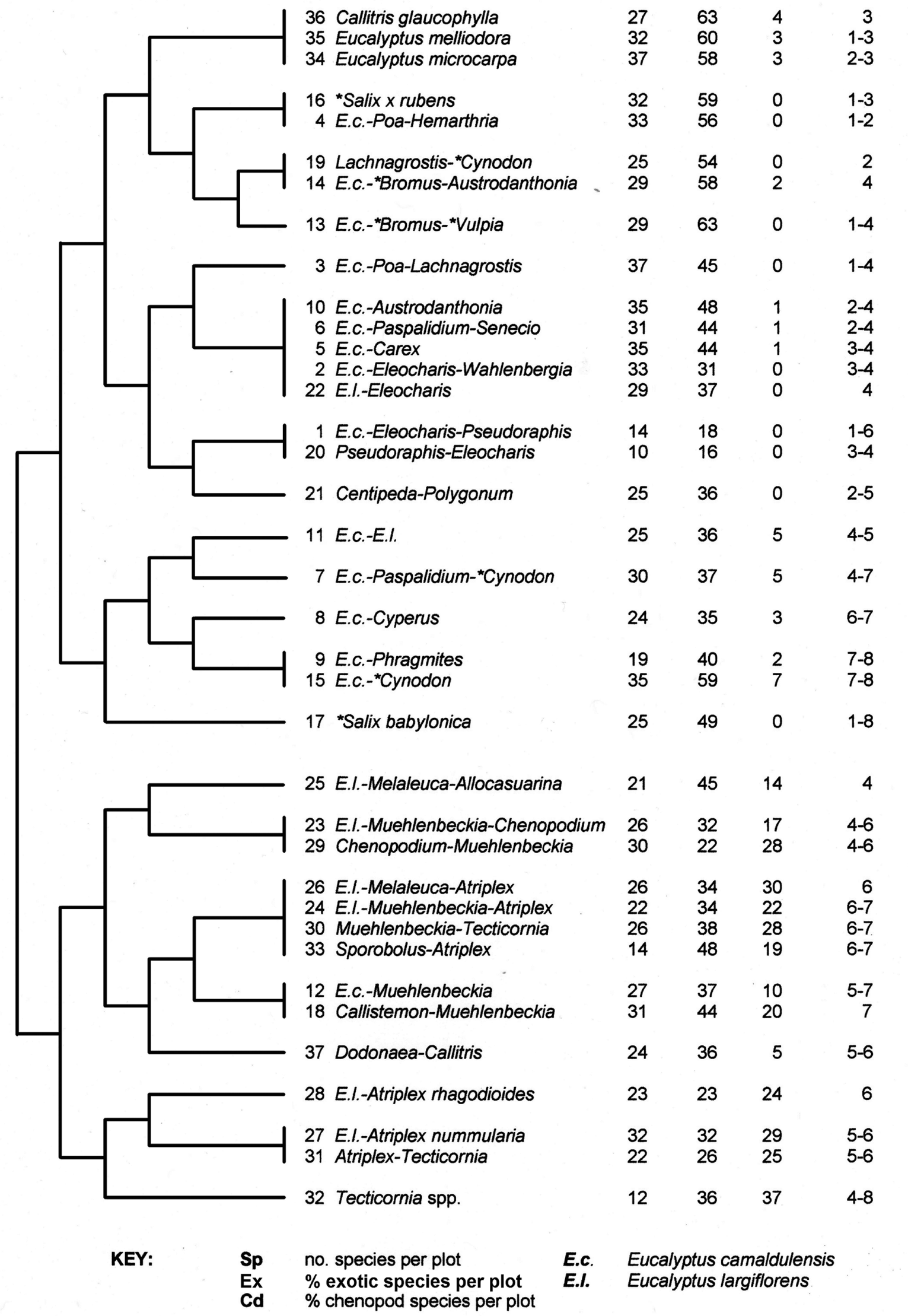

Fig. 2. TWINSPAN classification of the plant communities of the Murray floodplain. 
Grey Box Eucalyptus microcarpa, Yellow Box Eucalyptus melliodora and cypress pine Callitris species. A fourth zone, the permanent wetlands, was the subject of Pressey (1986) and was not included in the present study.

River Red Gum has the widest natural distribution of all eucalypts, growing along inland watercourses right across Australia and in some non-floodplain situations in South Australia and Victoria (Beadle 1981). River Red Gums line the Murray throughout the survey area except for Section 8, where they have been largely replaced by the exotic Weeping Willow Salix babylonica. In the flood-prone BarmahMillewa forests of Section 3, River Red Gums form tall, dense forests, some exceeding $45 \mathrm{~m}$ in height at maturity, and cover almost the entire floodplain, which is some $25 \mathrm{~km}$ wide. By contrast, in the semi-arid reaches, River Red Gums are restricted to the immediate vicinity of the river and its associated channels and billabongs. They occur here as woodlands rather than forests, often in a strip only one or two trees wide.

The understorey in the River Red Gum zone is predominantly herbaceous, with a mix of perennials, annuals and postflooding ephemerals. Prominent, widespread species include Warrego Summer-grass Paspalidium jubiflorum, Moira Grass Pseudoraphis spinescens, Common Spike-rush Eleocharis acuta, Spiny Sedge Cyperus gymnocaulos, Common Sneezeweed Centipeda cunninghamii, Cotton Fireweed Senecio quadridentatus and River Bluebell Wahlenbergia fluminalis.

Black Box is less widespread in Australia than River Red Gum, being restricted to inland floodplains of the south-east (Beadle 1981). It is also less widespread along the Murray, where it occurs in the semi-arid reaches from about the upper junction of the Edward River downstream to Mannum. Black Box is rare in Section 3, occurring only in small stands on the outer margin of the floodplain (Chesterfield et al. 1984), whereas in Section 6 the Black Box zone covers most of the floodplain.

The Black Box communities generally have a lower, more open tree layer than the River Red Gum communities, forming woodlands rather than forests. They also have a shrubbier understorey. In addition, the Black Box zone includes extensive shrublands, lacking a tree layer but otherwise similar in floristic composition to the adjacent Black Box woodlands. The principal shrub species are Lignum Muehlenbeckia florulenta, Dryland Tea-tree Melaleuca lanceolata and various chenopods - Nitre Goosefoot Chenopodium nitrariaceum, Silver Saltbush Atriplex rhagodioides, Old-man Saltbush Atriplex nummularia, Bladder Saltbush Atriplex vesicaria and Desert Glasswort Tecticornia triandra.

\section{Plant Communities}

The COMPCLUS and TWINSPAN analyses distinguished 37 plant communities described in Appendix 1, grouped into the three vegetation zones. As a one-off sampling, the survey did not encompass the dynamics of the understorey composition, especially the effects of ephemerals. These effects are most apparent in the changing nature of the vegetation in temporary wetlands at different stages of the flooding cycle. However, the classification presented here is a broad one and ephemerals are unlikely to have a major influence. This is borne out by observations during the survey that some River Red Gum plots had been recently flooded while others in similar situations had missed out on flooding, yet still grouped with the flooded plots in the analyses.

Floristic relationships among the communities, as indicated by the TWINSPAN analysis, are shown by a dendrogram (Fig. 2) and a two-way classification of communities and species (Appendix 2). The primary TWINSPAN division is between the River Red Gum and Black Box zones (Fig. 2). However, the Eucalyptus largiflorens - Eleocharis community groups with the River Red Gum communities, while the Eucalyptus camaldulensis - Muehlenbeckia community, and the related Callistemon - Muehlenbeckia shrubland, group with the Black Box communities. The communities of the rises do not separate as a group but are split between the River Red Gum and Black Box groupings. The communities of Riverine Plain rises (the Callitris glaucophylla, Eucalyptus melliodora and Eucalyptus microcarpa communities) show affinity with weedy River Red Gum communities because of the many weed species that they share. The Dodonaea - Callitris community of Mallee Zone rises shows more affinity with Black Box communities from the same zone.

Within the River Red Gum grouping, the major division is between Riverine Plain/Headwaters Zone communities of the upper Murray (Sections 1 to 4) and Mallee Zone communities of the lower Murray (Sections 5 to 8). The Riverine Plain/ Headwaters Zone subgroup divides into the more weedy communities (including the communities of the Riverine Plain rises) and the less weedy ones. The less weedy communities further divide into frequently flooded and infrequently flooded communities. The frequently flooded communities include the tallest River Red Gum forests (the Eucalyptus camaldulensis - Eleocharis - Pseudoraphis community) and also herbaceous communities from sites where flooding is too frequent for tree growth (the Pseudoraphis - Eleocharis and Centipeda-Polygonum communities). The Mallee Zone subgroup consists of the Salix babylonica community and various Eucalyptus camaldulensis communities, the latter dividing into those typical of Section 5 and those typical of South Australia.

Within the Black Box grouping, the major division is between the communities of the outer floodplain (characterised by the perennial saltbushes, Atriplex rhagodioides, Atriplex nummularia and Atriplex vesicaria, occurring chiefly in Section 6) and those of the inner floodplain (characterised by Lignum Muehlenbeckia florulenta). The inner floodplain subgroup also includes the Dodonaea-Callitris community of the rises and the uncommon Eucalyptus largiflorens Melaleuca communities, which are also associated with higher ground. The outer floodplain subgroup includes the samphire Tecticornia species communities of the most saline sites. 
In both Black Box subgroups there is a division between the South Australian communities (e.g. the Eucalyptus largiflorens - Muehlenbeckia - Atriplex and Eucalyptus largiflorens - Atriplex rhagodioides communities) and their counterparts across the border in New South Wales and Victoria (the Eucalyptus largiflorens - Muehlenbeckia - Chenopodium and Eucalyptus largiflorens - Atriplex nummularia communities). The reason for this division is unclear. It contrasts with the major division among the River Red Gum communities, which is between the Mallee Zone and the Riverine Plain/Headwaters Zone, which are more obviously different environments.

An alternative representation of floristic relationships is provided by the DECORANA ordination (Fig. 3). The four main groups of the TWINSPAN classification can be distinguished in the ordination, arranged along Axis 1 in a sequence: Riverine Plain/Headwaters Zone River Red Gum communities, Mallee Zone River Red Gum communities, inner Black Box zone communities, and outer Black Box zone communities. Axis 2 separates communities within the main groups.

The axes in Figure 3 have been derived entirely from the floristic data but also reflect environmental gradients. Axis 1, the principal axis, corresponds closely with the distribution of chenopods. There is a highly significant correlation between a community's Axis 1 score and the mean proportion of chenopod species per plot in that community $(\mathrm{r}=0.91, \mathrm{P}<<0.001$, arcsine transformation of proportions), accounting for $84 \%$ of the variation in Axis 1 scores. Most, perhaps all, chenopods are salt-tolerant (Waisel 1972), suggesting that Axis 1 is primarily a salinity gradient, reflecting the more saline conditions in the Mallee Zone compared with the Riverine Plain, and the increase in salinity across the floodplain (since less frequent flooding means less frequent flushing of accumulated salt). The strong relationship between floristics and salinity levels emphasises the major impact that increasing salinisation has on the floodplain flora.

Interpretation of Axis 2 is more difficult. It appears to represent a combination of floristic variation associated with changes in flooding frequency, climate and other factors.

On a local scale, there is typically a marked change in vegetation across the floodplain, and often a mosaic of different communities. For example, Figure 4 is a diagrammatic representation of the vegetation pattern at one

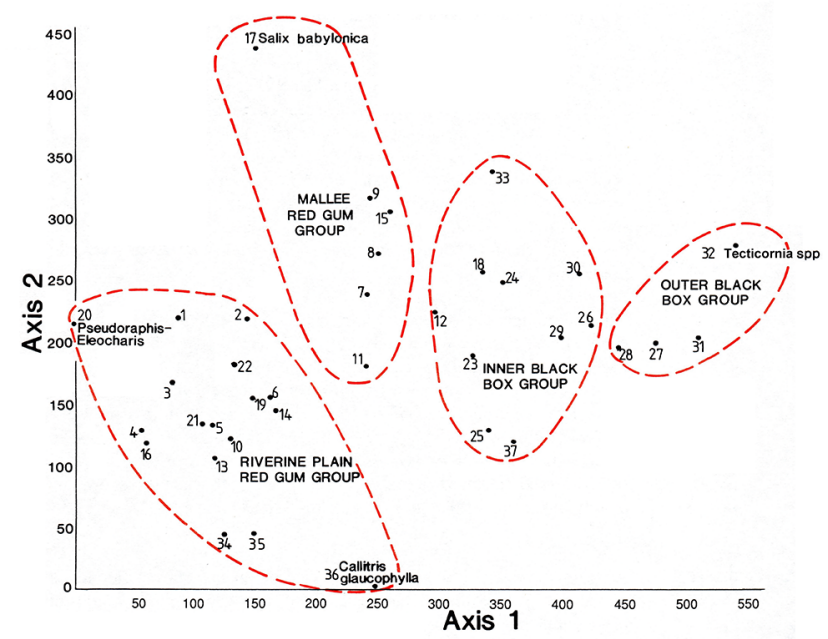

Fig. 3. DECORANA ordination of the plant communities of the Murray floodplain. Communities numbered as in Appendix 1.

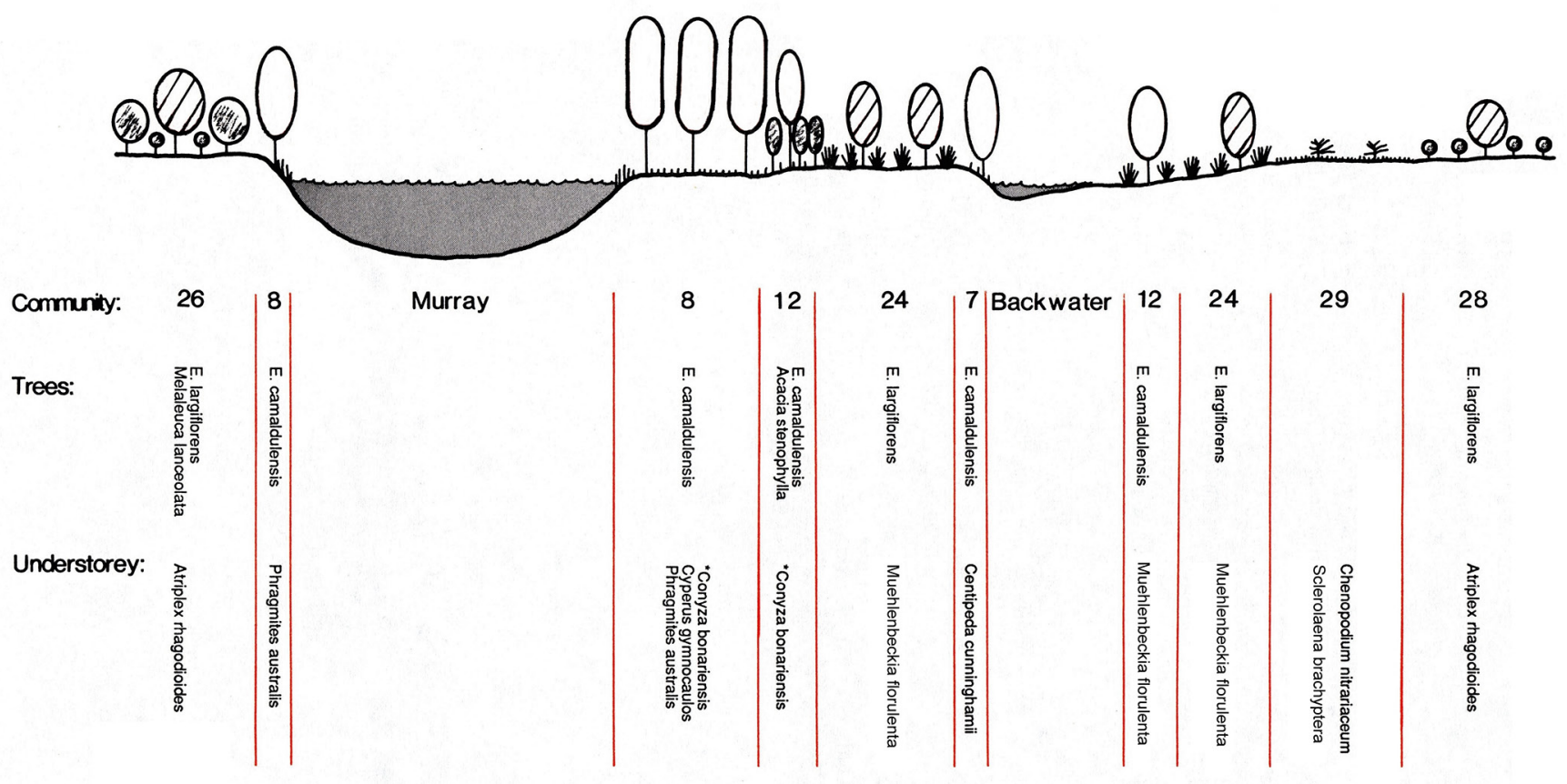

Fig. 4. Vegetation change across the floodplain near Murtho in Section 6. 
locality in the Murtho area, north of Renmark, in Section 6, where 12 plots were sampled. The changes portrayed occur over a distance of about $1 \mathrm{~km}$. Such complex patterns are a result of the variation in landform, soil and hydrology across the floodplain, which is determined chiefly by fluvial processes, both present and past (van der Sommen 1987).

Landform is especially important, since minor differences have a major effect on the frequency and duration of flooding. This is illustrated by vegetation patterns on the riverbank adjacent to the water. Typically, there is a series of narrow bands of different plant species at different heights above the water, i.e. different flooding regimes. For example, at a drying billabong on Ulupna Island in Section 2, there was a sequence from the water's edge of Amphibromus fluitans, Lachnagrostis filiformis, Eleocharis species, Carex tereticaulis and Bromus diandrus over a distance of about 10 $\mathrm{m}$ and a change in elevation of about $1 \mathrm{~m}$. Such sequences show how closely linked are local vegetation patterns to flooding patterns.

\section{Plant species}

A total of 499 plant species, subspecies and varieties were recorded in the 335 survey plots, of which 316 (63\%) were native and 183 (37\%) were exotic (Appendix 3). Among the native species, the dominant plant families, in decreasing order, were the Asteraceae (daisies), Chenopodiaceae (chenopods), Poaceae (grasses), Cyperaceae (sedges) and Fabaceae (wattles and peas) (Table 1). Among the exotic species, the dominant families were the Poaceae, Asteraceae, Fabaceae and Brassicaceae (cress family). The Myrtaceae (eucalypt family), although represented by relatively few species, all native, were the dominant trees.

The prominence of River Red Gum Eucalyptus camaldulensis throughout the survey area gives a misleading impression of uniformity in the vegetation. Most species have a far more restricted distribution, reflecting the changes in climate, geomorphology and soils along the river (Appendix 3). Apart

Table 1. Major plant families of the floodplain flora

Taxa include species, subspecies and varieties

\section{Family}

Poaceae (grasses)

Asteraceae (daisies)

Chenopodiaceae (chenopods)

Fabaceae (wattles and peas)

Cyperaceae (sedges)

Brassicaceae (cress family)

Polygonaceae (dock family)

Ranunculaceae (buttercup family)

Juncaceae (rushes)

Other families

Total

\section{Number of taxa recorded}

Native Exotic Total

$\begin{array}{lll}38 & 44 & 82 \\ 46 & 30 & 76 \\ 42 & 2 & 44 \\ 14 & 23 & 37 \\ 17 & 2 & 19 \\ 3 & 12 & 15 \\ 10 & 4 & 14 \\ 8 & 3 & 11 \\ 8 & 1 & 9 \\ 130 & 62 & 192 \\ \mathbf{3 1 6} & \mathbf{1 8 3} & \mathbf{4 9 9}\end{array}$

from Eucalyptus camaldulensis, only 12 species (five native and seven exotic, predominantly Asteraceae and Poaceae) were recorded in every river section (Appendix 3). The changing floristic composition of the vegetation along the river is reflected in the restricted distribution of most plant communities (Fig. 2).

The TWINSPAN analysis provided a two-way classification of species and communities (Appendix 2) for 176 'species' that are relatively common, at least in certain communities (including several pairs or groups of species not consistently distinguished in the field and thus combined for analysis). The species divide into four major groups: 69 species (39\%) closely associated with the River Red Gum zone; 29 (16\%) found in both River Red Gum and Black Box zones but more common in the former; 22 (13\%) equally common in both River Red Gum and Black Box zones; and 56 (32\%) associated mainly with the Black Box zone, although many also occur in River Red Gum communities, especially those of the Mallee Zone.

The Asteraceae and Poaceae are well represented in all four groups. However, other major families tend to be associated with either the River Red Gum or the Black Box zone. The Cyperaceae, Fabaceae and Juncaceae occur chiefly in the herbaceous understorey of the River Red Gum zone, as do most of the Polygonaceae except Lignum Muehlenbeckia florulenta, which is a common shrub of the Black Box zone. The characteristic family of the Black Box zone is the Chenopodiaceae, which is co-dominant there with the Asteraceae and Poaceae. The shrubby nature of the Black Box zone understorey is chiefly due to the abundance of chenopods and Lignum.

The prominence of the salt-tolerant Chenopodiaceae is indicative of the more saline conditions in the Black Box zone compared with the River Red Gum zone. The results of the DECORANA ordination (Fig. 3) suggest that salinity is the most important factor responsible for the floristic differences between the two zones, although flooding frequency may be the more important factor for the two tree species.

The communities with the lowest number of species per plot were Communities 1 and 20 in the River Red Gum zone, and Communities 32 and 33 in the Black Box zone (Fig. 2, Appendix 1). Communities 1 (Eucalyptus camaldulensis Eleocharis acuta-Pseudoraphis spinescens open-forest) and 20 (Pseudoraphis spinescens - Eleocharis acuta herbland) are both subject to frequent and prolonged flooding, which may limit the number of species capable of surviving. Communities 32 and 33 are associated with high levels of disturbance, Community 32 (Tecticornia pergranulata Tecticornia indica shrubland) occurring in highly saline sites and Community 33 (Sporobolus mitchellii - Atriplex leptocarpa grassland) in overgrazed sites.

The communities with the highest number of species per plot were Communities 3 (Eucalyptus camaldulensis Poa labillardierei - Lachnagrostis filiformis open-forest), 5 (Eucalyptus camaldulensis - Carex tereticaulis openforest) and 10 (Eucalyptus camaldulensis - Austrodanthonia caespitosa woodland) in the River Red Gum zone, and 
Community 34 (Eucalyptus microcarpa open-forest) in the floodplain rises zone (Fig. 2, Appendix 1). The three River Red Gum communities had high numbers of both native and exotic species. The Grey Box (Eucalyptus microcarpa) community was less rich in native species, but had the highest number of exotic species per plot of any community.

\section{Weed invasion}

$37 \%$ of all plant species recorded were exotic (183 of 499 species). Weeds were common throughout the survey area, but were most prevalent in the wetter climates at the upper and lower ends of the river, in Sections 1,2 and 8. The median number of exotic species per plot exceeded or equalled the number of native species in these three sections of the river, whereas native species outnumbered exotic species in the other river sections (Fig. 5). The highest numbers of native species and lowest numbers of exotic species per plot were recorded in Sections 5 and 6 (Fig. 5). Differences between river sections were statistically significant (Kruskal Wallis test). In particular, the number of native species per plot was significantly higher in Sections 5 and 6 than in Section 8 $(P=0.02)$, and the number of exotic species per plot was significantly higher in Sections 1, 2 and 8 than in Sections 5, 6 and $7(P<<0.001)$.

Differences were also evident between the vegetation zones (Fig. 6). There was no significant difference between the three zones in the number of native species per plot, but the number of exotic species per plot was significantly lower in the Black Box zone than in the River Red Gum zone and the floodplain rises (Kruskal Wallis test, $P<<0.001$ ). Exotic species strongly influenced the community classification and were the dominant overstorey species in two communities (Communities 16 and 17, dominated by willows Salix species). Exotic species dominated the understorey in another eight communities (Fig. 2). These communities included one South Australian River Red Gum community (Community 15), three Riverine Plain River Red Gum communities (Communities 4, 13 and 14), three communities of Riverine Plain rises (Communities 34, 35 and 36), and one grassland community colonising point bar deposits (beaches) on the Riverine Plain (Community 19).

The high level of weed invasion reflects the history of intensive disturbance along the Murray since the 1830s (Frith and Sawer 1974) and the susceptibility of floodplain vegetation to weed invasion (de Waal et al. 1994, Hood and Naiman 2000). Recent studies have indicated that reduced flooding as a result of river regulation and water extraction has favoured exotic species (Stokes et al. 2010, Catford et al. 2011). However, other disturbance factors, including agricultural activities, urban development, recreational activities and logging, have also promoted weed invasion.

\section{Eucalypt health}

The overall condition of eucalypt trees along the Murray during the 1987-88 survey was assessed as 68\% healthy, $21 \%$ unhealthy (at least $40 \%$ of the crown dead) and $11 \%$ dead (not including stumps), based on a sample of 3649 trees. The species involved were predominantly River Red Gum (Eucalyptus camaldulensis) and Black Box (Eucalyptus largiflorens), with a few Yellow Box (Eucalyptus melliodora) and Grey Box (Eucalyptus microcarpa) on the rises.

Eucalypt health was best in Sections 1 and 2, and became steadily worse downstream, being poorest in Sections 6, 7 and 8 below the Darling Junction, particularly in terms of the high proportion of dead trees in these sections (Fig. 7). The relationship between eucalypt health and river section was highly significant (chi square test, $P<<0.001$ ). The condition

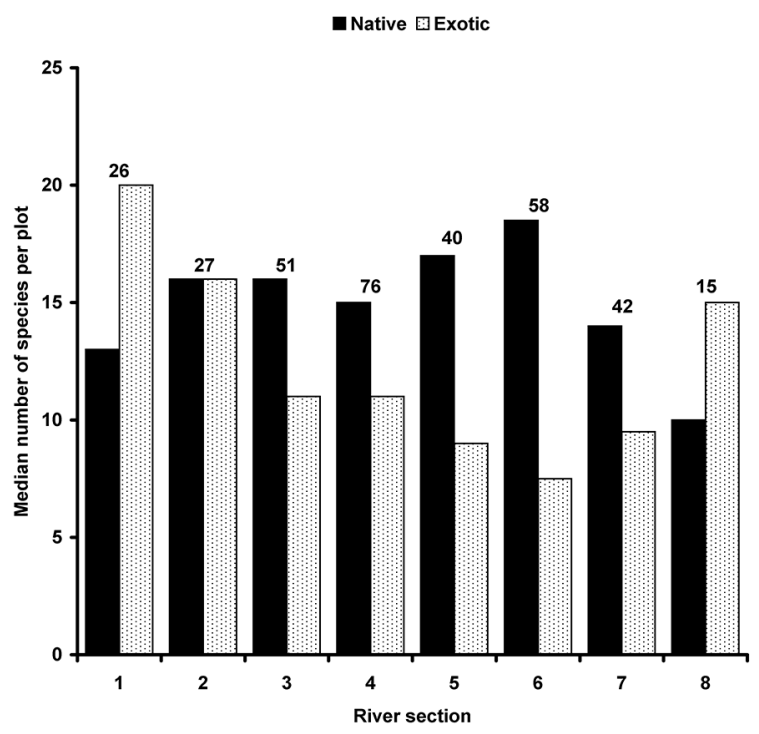

Fig. 5. Median numbers of native and exotic species per plot in each river section. Figures above the columns are the numbers of sample plots.

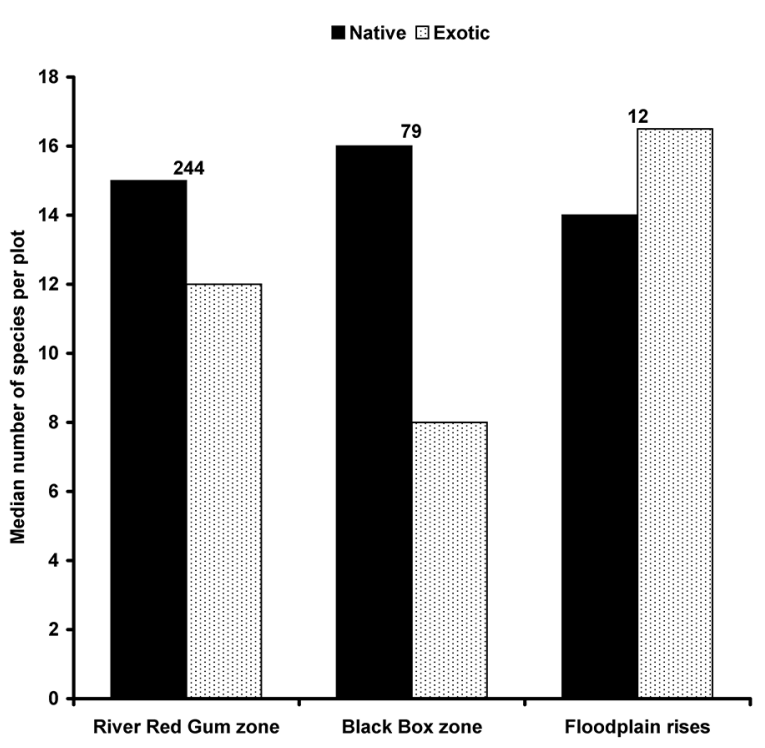

Fig. 6. Median numbers of native and exotic species per plot in each vegetation zone. Figures above the columns are the numbers of sample plots. 
of eucalypt trees below the Darling Junction was assessed as $60 \%$ healthy, $18 \%$ unhealthy and $22 \%$ dead (sample of 1053 trees). By comparison, $84 \%$ of the trees in Sections 1 and 2 were healthy, $14 \%$ unhealthy and only $2 \%$ dead (sample of 559 trees). The many dead trees along the river in South Australia in the 1980s were also noted by Thompson (1986).

Obvious causes of tree death in Sections 6, 7 and 8 were soil salinisation (particularly in Sections 6 and 7, involving both River Red Gum and Black Box) and raised river levels from construction of weirs, resulting in permanent inundation of low-lying areas that were formerly temporary wetlands (particularly in Sections 7 and 8, River Red Gum only).

While some low-lying sites have become wetter as a result of river regulation, the Murray floodplain in general has become drier through reduced flooding because of the high level of water extraction, mainly for irrigation, throughout the Murray-Darling Basin. The reduction in flooding frequency has been greatest in the lower Murray, below the Darling Junction, corresponding to the part of the floodplain with the poorest tree health in 1987-88. Flows in the lower Murray have been approximately halved, and the frequency and duration of small, medium and large floods have all been significantly reduced (Walker and Thoms 1993, Maheshwari et al. 1995, Dyer 2002, Roberts 2004, CSIRO 2008). Reduced flooding means not only less water for the trees but also increasing soil salinisation because of less flushing of accumulated salt from the saline Mallee Zone floodplain. The situation was exacerbated during the prolonged Millenium Drought after our survey, when overbank flows were largely absent along the lower Murray between 1994 and 2010 (Holland et al. 2013).

Severe declines in eucalypt health were reported during the Millenium Drought. Smith and Kenny (2005) reported that $49 \%$ of River Red Gum trees and $62 \%$ of Black Box trees on the Murray floodplain in South Australia were unhealthy or dead. Brett Lane and Associates (2005) reported that the

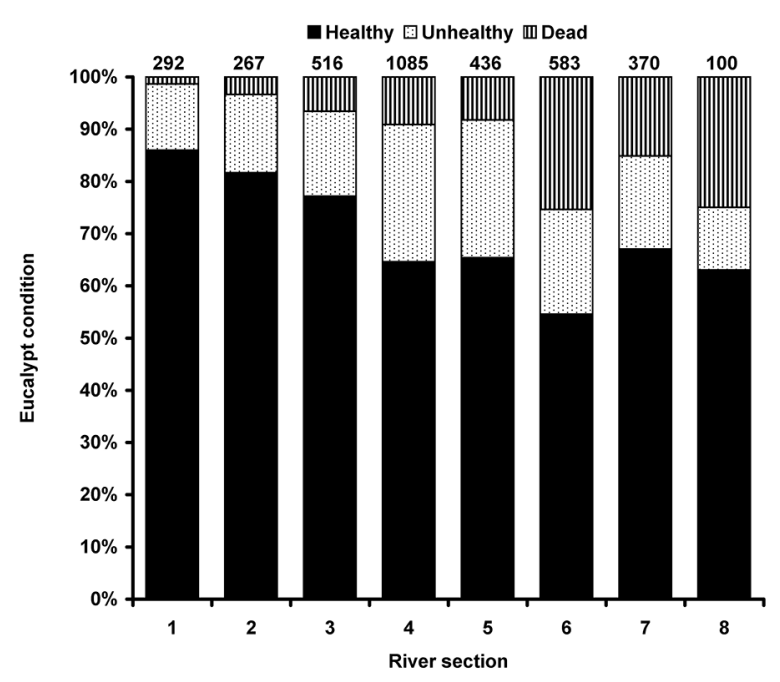

Fig. 7. Condition of eucalypt trees in each river section (all species combined). Figures above the columns are sample sizes. proportion of stressed trees in the Chowilla anabranch region of South Australia increased from 54\% in 2002 to $89 \%$ in 2004, with River Red Gum trees most affected. The MurrayDarling Basin Commission (2003) reported that about $80 \%$ of River Red Gum trees on the lower Murray were stressed to some degree, with 20 to $30 \%$ severely stressed. Eucalypt health deteriorated further as the drought continued between 2003 and 2009. Cunningham et al. (2009) assessed that $72 \%$ of River Red Gum stands, and $92 \%$ of Black Box stands along the river were in a stressed condition in 2009, and that the extent of stressed stands had been $66 \%$ lower in 2003. The situation was worse in the Mallee Zone than in the Riverine Plain. Following the breaking of the drought with a major flood over the summer of 2010-11, a significant improvement in the condition of both River Red Gum and Black Box trees was reported at several sites along the Murray in 2012 (Bennetts and Jolly 2012, Henderson et al. 2012a, 2012b).

Another factor that can affect River Red Gum condition is the Gum Leaf Skeletoniser Uraba lugens, a moth whose larvae feed on eucalypt foliage, particularly River Red Gums. The larvae seldom kill the trees but may cause severe defoliation over large areas (for example, some 40000 ha of River Red Gum forest along the Murray and Goulburn Rivers in 1975) and drastically check growth (Harris 1986, Harris et al. 1977). Major outbreaks occur in roughly tenyear cycles, when the forest is almost completely defoliated. Moth populations then crash and the trees recover rapidly. There was evidence of Gum Leaf Skeletoniser activity at some sites during our 1987-88 survey, for example, Nyah State Forest in Section 4, but this was limited in extent and is likely to be a negligible influence on the tree health measures in Figure 7.

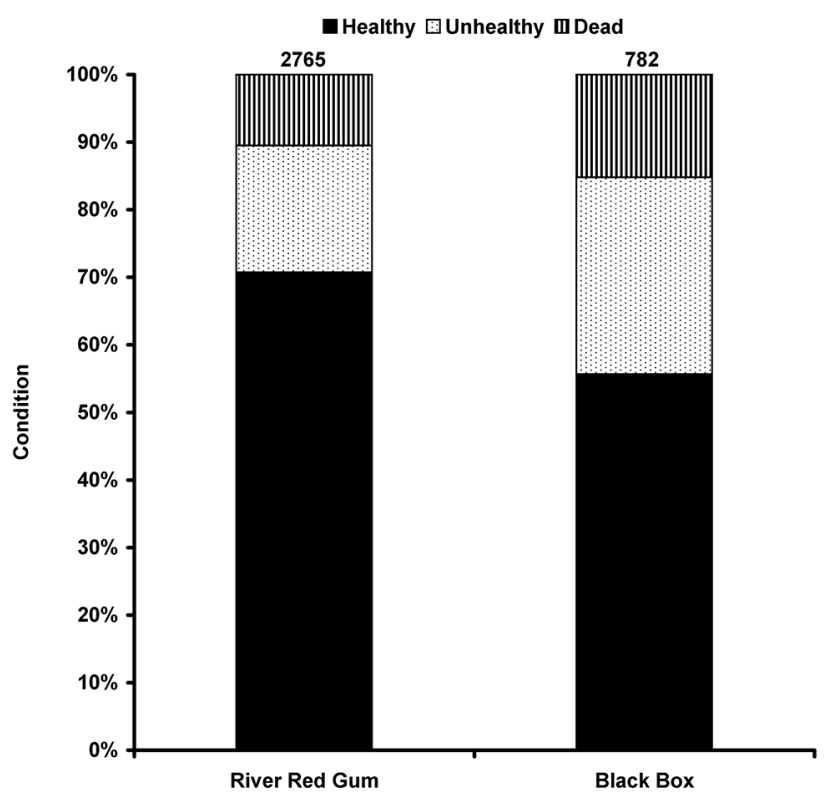

Fig. 8. Comparison of the condition of River Red Gum and Black Box trees along the Murray. Figures above the columns are sample sizes. 
The condition of Black Box trees along the Murray was significantly worse than the condition of River Red Gum trees during our 1987-88 survey (Fig. 8, chi square test, $P<<$ 0.001 ). Overall, $71 \%$ of River Red Gum trees were healthy, $19 \%$ unhealthy and 10\% dead (sample of 2765 trees), whereas only $56 \%$ of Black Box trees were healthy, $29 \%$ unhealthy and $15 \%$ dead (sample of 782 trees). Subsequent studies by Smith and Kenny (2005) and Cunningham et al. (2009) during the Millennium Drought also reported Black Box in worse condition than River Red Gum.

Black Box health has been studied intensively in the Chowilla anabranch region in Section 6 in South Australia (Eldridge et al. 1993, Walker et al. 1996, Jolly 1996, Jolly et al. 1993, 1996, Taylor et al. 1996, Overton et al. 2006), where there has been extensive and increasing dieback of Black Box. Salinisation of floodplain soils as a result of the hydrological management of the River Murray has been identified as the primary cause of the dieback. The higher river level after construction of Lock 6 has caused groundwater levels beneath the floodplains to rise, while water extractions upstream have reduced flooding. The higher water tables have resulted in increased soil salinity, while the decreased incidence of overbank floods has reduced leaching of salt from the floodplain soils. These combined processes have led to the disturbance of the natural salt balance in the soil profile, leading to salt accumulation and tree deaths. It should be noted, however, that in the upper Murray, where the groundwater is predominantly fresh, dieback of floodplain trees is associated with falling groundwater levels rather than rising ones (Cunningham et al. 2011).

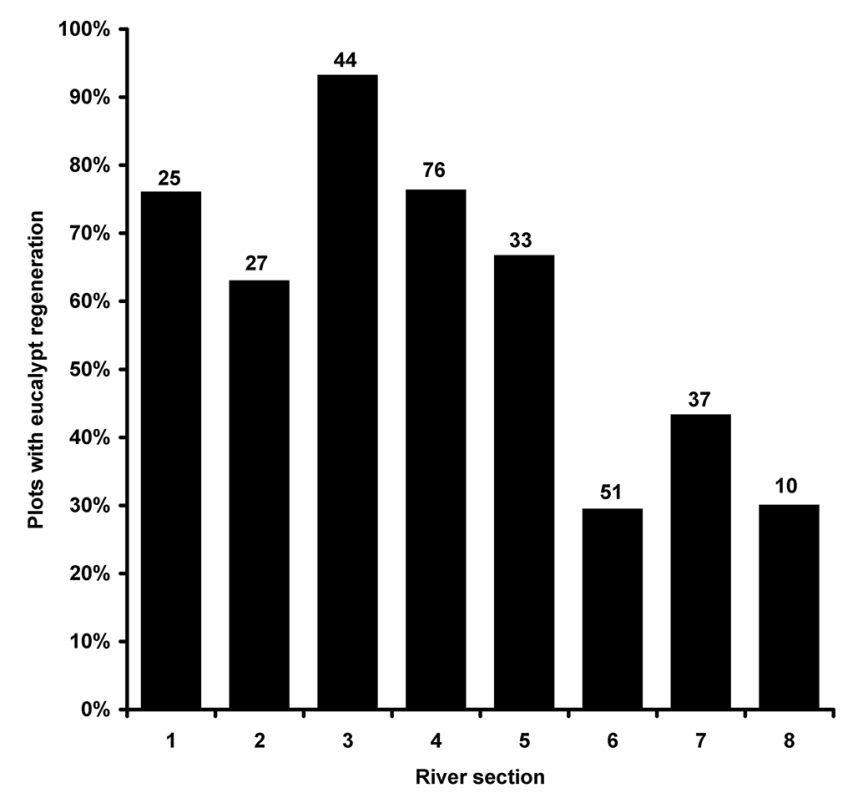

Fig. 9. Frequency of eucalypt regeneration in each river section (all species combined). Figures above the columns are the numbers of sample plots.

\section{Eucalypt regeneration}

The overall density of eucalypt regeneration in the survey area during the 1987-88 survey was 467 regenerants per ha, based on 303 sample plots in eucalypt vegetation (including all regenerants over $5 \mathrm{~cm}$ high and up to $20 \mathrm{~cm}$ diameter at breast height). River Red Gum regeneration was much more frequent and denser than Black Box regeneration. It was evident in $69 \%$ of the 248 River Red Gum plots but only $29 \%$ of the 76 Black Box plots, a significant difference (chi square test, $P<<0.001)$. The overall density of Black Box regenerants (124 per ha) was less than a quarter of the density of River Red Gum regenerants (525 per ha).

A similar difference between the two species has been reported by George et al. (2005), in a population viability analysis of floodplain eucalypts at Banrock Station in Section 7. The Black Box population at this site appears to lack sufficient regeneration to compensate for adult mortality, implying that the population is unlikely to survive in the long term, whereas the River Red Gum population has a better balance of age classes and a better chance of survival.

Eucalypt regeneration also varied significantly with river section (Fig. 9, chi square test, $P \ll<0.01$ ). Like the health of the trees themselves, regeneration was worse in the lower Murray below the Darling Junction, in Sections 6, 7 and 8, in terms of both the percentage of plots with regeneration $(35 \%$ of plots below the Darling versus $77 \%$ of plots upstream; Fig. 9) and the density of regeneration (115 regenerants per ha below the Darling versus 635 per ha upstream; Fig. 10). The poor eucalypt regeneration in the lower Murray is due to a combination of factors, including reduced flooding, increasing salinisation, overgrazing and less post-logging regeneration.

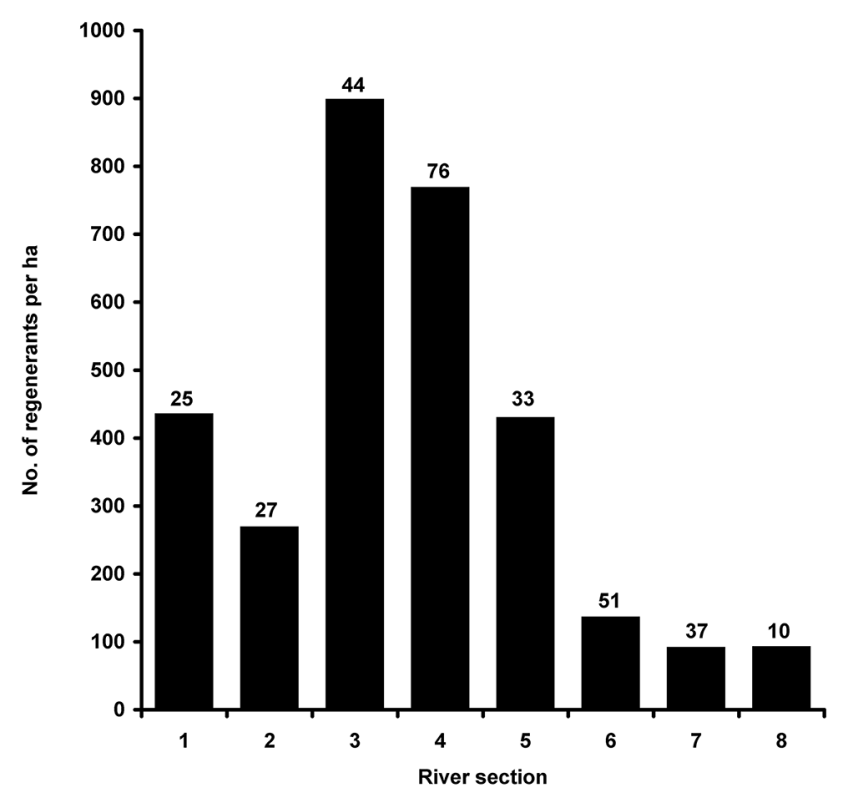

Fig. 10. Density of eucalypt regeneration in each river section (all species combined). Figures above the columns are the numbers of sample plots. 
Natural regeneration of floodplain eucalypts is episodic (George et al. 2005) and large-scale regeneration occurs after major floods (Treloar 1959). Moisture is one of the most critical factors controlling the germination and survival of River Red Gum seedlings, with optimal conditions being winter and spring flooding followed by a mild summer (Jacobs 1955, Dexter 1967, 1978). Regeneration of Black Box is also promoted by flooding, with seedlings typically becoming established in a narrow belt at the maximum extent of the flood (Cunningham et al. 1981).

Salinisation also impacts on eucalypt regeneration. During the 1987-88 survey, 13 plots were sampled in vegetation where there had been extensive death of eucalypts from salinisation. All were in Sections 6 and 7, constituting 15\% of the 88 plots in eucalypt vegetation in these two river sections. The density of eucalypt regeneration in the 13 plots was low: a mean of 15 regenerants per ha compared with a mean of 135 per ha in the other 74 eucalypt plots in these two sections.

The poor and patchy nature of River Red Gum regeneration in South Australia in the 1980s was also noted by Thompson (1986), Venning (1984) and Kiddle (1987), who concluded that grazing was severely restricting regeneration. This conclusion was based on the observation that where regeneration occurs it is often in situations where there is some protection from grazing. Similar observations were made during the 1987-88 survey. Evidence of grazing animals in the survey plots included livestock (mainly sheep Ovis aries and cattle Bos taurus, occasionally horses Equus caballus), feral animals (mainly European Rabbits Oryctolagus cuniculus, occasionally pigs Sus scrofa) and native animals (mainly kangaroos, occasionally Emus Dromaius novaehollandiae). Kangaroo droppings were not identified to species, but general observations indicated that they were mainly Eastern Grey Kangaroos Macropus giganteus on the Riverine Plain and Western Grey Kangaroos Macropus fuliginosus, plus some Red Kangaroos Macropus rufus, in the Mallee Zone.

On the Murrumbidgee River floodplain, sheep and cattle grazing is known to have a strong negative impact on River Red Gum regeneration, depending on stocking rate (Robertson and Rowling 2000, Jansen and Robertson 2001). In Barmah State Forest in Section 3, Dexter (1967, 1978) found that grazing by cattle, kangaroos and rabbits had only a minor effect on River Red Gum regeneration during good years, but their impact could be substantial during drought years. Seedling establishment in Black Box is also known to be severely impacted by grazing (Chettle 1959, Treloar 1959, Duncan et al. 2007), especially as the leaves of Black Box appear to be more palatable than those of River Red Gum (Jacobs 1955).

Another factor involved in the paucity of eucalypt regeneration on the lower Murray floodplain is logging history. Logging promotes regeneration by opening out the canopy (Jacobs 1955, Dexter 1967). For example, Treloar (1959) reported that the survival rate for Black Box seedlings increased four to five fold if the overhanging canopy of the parent tree was trimmed. Logging, particularly of River Red Gums, has been an important industry along the Murray in New South Wales and Victoria, but less so in South Australia. There was evidence of logging (stumps in or near the plot) in $78 \%$ of the eucalypt plots in Sections 1 to 5 , but only $26 \%$ of the plots in Sections 6 to 8 (Fig. 11). The higher intensity of logging in the upper and middle Murray has promoted more regeneration in these sections of the river.

Prolific River Red Gum regeneration was observed in some depressions within the River Red Gum zone. Regeneration was much more abundant (4065 regenerants per ha) in Community 21, Centipeda cunninghamii - Polygonum plebeium herbland, which is characteristic of such sites, than in any other community (Appendix 1). The importance of these depressions was also noted in a regeneration survey in South Australia (Kiddle 1987). These sites are subject to frequent flooding, both from river flows and from local rain. Seeds come from surrounding River Red Gums and there is extensive germination after flooding, although most of the seedlings are killed by subsequent flooding. Saplings only become established around the edges of the depressions.

Prolific River Red Gum regeneration was also observed on the edges of the extensive Moira Grass (Pseudoraphis spinescens) plains (Community 20, Pseudoraphis spinescens - Eleocharis acuta herbland) in Barmah State Forest in Section 3. In one sample plot near Hut Lake this regeneration averaged $11 \mathrm{~m}$ in height with a density of 7400 regenerants per ha (mixed ages), representing a young stand of Community 1, Eucalyptus camaldulensis - Eleocharis acuta - Pseudoraphis spinescens open-forest, colonizing the outer parts of a Moira Grass plain. There was an abrupt boundary between the regeneration and the remaining Moira Grass plain, from which River Red Gum trees and regeneration were almost entirely absent.

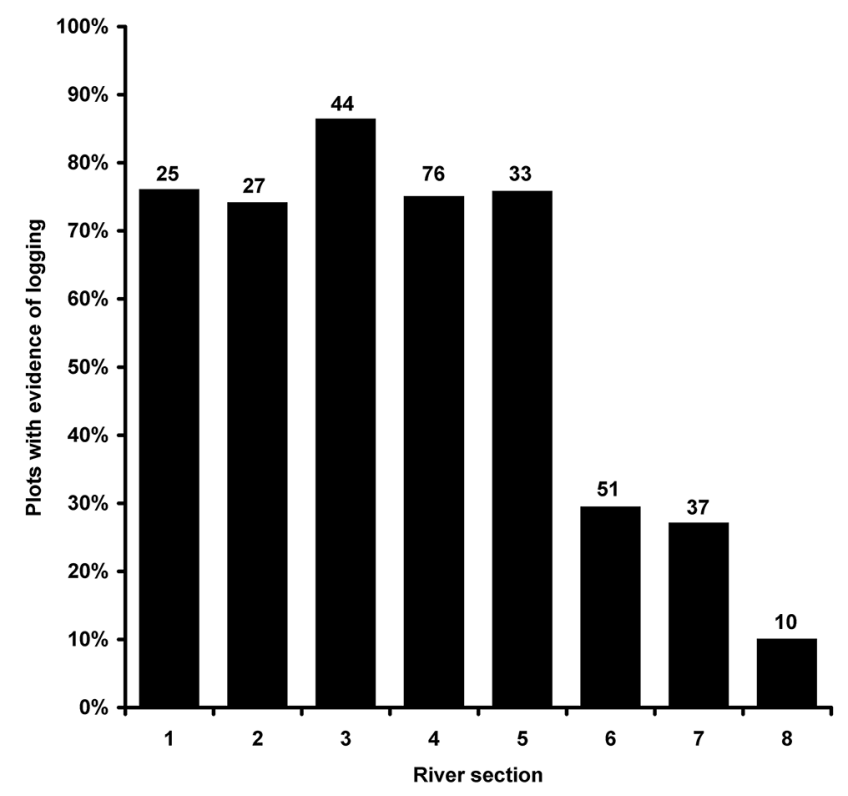

Fig. 11. Frequency of plots with evidence of logging (stumps in or near the plot) in each river section. Figures above the columns are the numbers of plots sampled. 
Chesterfield (1986) estimated that this invasion of the Moira Grass plains by River Red Gums covered about $4 \%$ of the total area of Barmah State Forest in the 1980s. It appears to be a consequence of the reduced frequency of minor flooding since river regulation, allowing River Red Gums to become established where flooding was once too frequent and prolonged for them (Dexter et al. 1986, Bren 1992).

The changes to flood regimes in Section 3, and their effects on River Red Gum growth and regeneration, have been the subject of numerous studies (Dexter 1967, 1978, Dexter et al. 1986, Chesterfield 1986, Chesterfield et al. 1984, Bren 1988, 1992, Bren and Gibbs 1986). Major floods in this section have been little affected by river regulation but there has been a reduced frequency of minor flooding in winter and spring. This has been linked to the invasion of the Moira Grass plains by River Red Gums, but it has also meant less vigorous growth and regeneration of River Red Gums over large areas at slightly higher elevations.

\section{Effects of weirs}

Eleven weirs with locks (Locks 1 to 11 ) were constructed between Blanchetown and Mildura in the 1920s and 1930s, followed by construction of five barrages between the islands at the Murray mouth in the 1940s (Jacobs 1990). Hume Dam was also constructed in the 1920s and 1930s. The weirs and barrages are operated so that water levels upstream remain at or near a specified 'normal pool level' except during floods. Fluctuations in water level increase gradually upstream along the weir pools, reaching a maximum at the upper end of the weir pool, where the variability in water level is similar to natural conditions. From the Murray mouth to the top of the Lock 11 pool, some $92 \mathrm{~km}$ upstream of Mildura, the weir pools are continuous. As a result, water levels in this part of the river (Sections 6, 7 and 8, and the lower half of Section 5 ) are now generally higher and more stable than would have been the case under natural conditions. Between the Lock 11 pool and Hume Dam, the river is free-flowing and water levels fluctuate with variations in flow, except for weir pools at Euston (Lock 15), Torrumbarry (Lock 26) and Yarrawonga Weir on the Murray, and Stevens Weir on the Edward River.

The effects on floodplain vegetation of the more stable water levels in the lower Murray were investigated during the 1987-88 survey by comparing the vegetation immediately upstream (stable water levels) and downstream (fluctuating water levels) of Lock 2 near Taylorville in Section 7. Six plots were sampled upstream of the weir (three riverside plots and three on top of the bank) and six plots were sampled downstream (again, three riverside and three on top of the bank). All plots were $10 \mathrm{~m}$ by $40 \mathrm{~m}$, with the long axis parallel to the river.

The mean number of native species recorded per plot downstream of the weir $(15.7 \pm$ s.e. 1.2$)$ was significantly higher than the mean number upstream $(11.0 \pm$ s.e. 1.1$)$ (two-factor ANOVA, $P=0.02$, no significant difference between riverside and top of bank). The number of native species per plot upstream of the weir, where water levels are stable, was only about $70 \%$ of the number recorded per plot downstream of the weir, where water levels fluctuate. No significant differences were found for the number of exotic species recorded per plot.

There were also marked differences in the species composition of the floodplain vegetation upstream and downstream of the weir. In an agglomerative hierarchical classification of the 12 plots based on their plant species composition and cover/ abundance values, using the Bray and Curtis association measure and the Flexible UPGMA classification technique (PATN program), the main division was between the six plots upstream and the six plots downstream (Fig. 12). Secondary divisions were between riverside plots and plots on top of the bank, although one upstream riverside plot grouped with the upstream top of the bank plots.

Upstream of the weir, the river was fringed by reedbeds of Phragmites australis and Typha species, which ended abruptly at the weir and were absent downstream. Behind the reedbeds and on top of the bank, up to about $3 \mathrm{~m}$ above the pool level, the ground vegetation was dense and tall

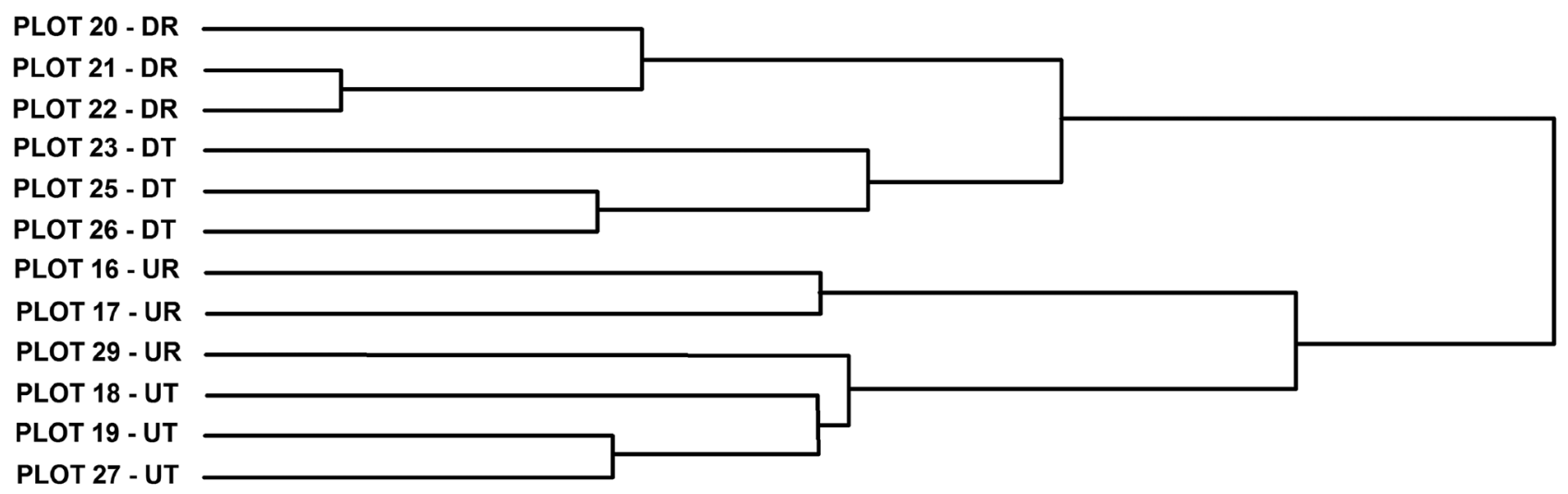

Fig. 12. Agglomerative hierarchical classification of plant species composition data from 12 sample plots at Lock 2 in Section 7 . $D=$ downstream of weir (fluctuating water levels), $\mathrm{U}=$ upstream of weir (stable water levels), $\mathrm{R}=$ riverside, $\mathrm{T}=$ top of bank. 
(averaging $65 \mathrm{~cm}$ high and $85 \%$ foliage cover), and was characterized by several large, herbaceous daisies, including the exotic species Aster subulatus, Cirsium vulgare and Urospermum picroides, and the native species Picris squarrosa and Sonchus hydrophilus. It is noteworthy that Sonchus hydrophilus, although endemic to Australia, appears to be a polyploid derivative of the exotic species Sonchus asper (Boulos 1973).

Lignum (Muehlenbeckia florulenta) formed a shrub layer on top of the bank both upstream and downstream of the weir, but was denser upstream (average cover 20\% versus 10\%) and extended there to the water's edge, occurring in all three riverside plots, whereas it was absent from the riverside plots downstream of the weir. The cosmopolitan species, Common Couch (Cynodon dactylon), which appears to be introduced along the Murray and is treated here as an exotic species even though native forms occur elsewhere in Australia, was present both upstream and downstream of the weir but was markedly more abundant in the riverside plots upstream.

Downstream of the weir, the ground vegetation was lower and more open, with a greater diversity of species. From the water's edge to the top of the bank, up to about $4 \mathrm{~m}$ above the water level (in September 1987), it averaged $45 \mathrm{~cm}$ in height and 50\% foliage cover. Species recorded solely or mainly downstream of the weir included the exotic species Brassica tournefortii, Hordeum murinum, Hypochaeris glabra and Reichardia tingitana, and the native species Acacia stenophylla, Austrostipa species (scabra group), Chamaesyce drummondii, Eclipta platyglossa, Enchylaena tomentosa, Pseudognaphalium luteoalbum and Vittadinia cuneata. Also, Cyperus gymnocaulos, although present in all 12 plots, was much more abundant downstream of the weir.

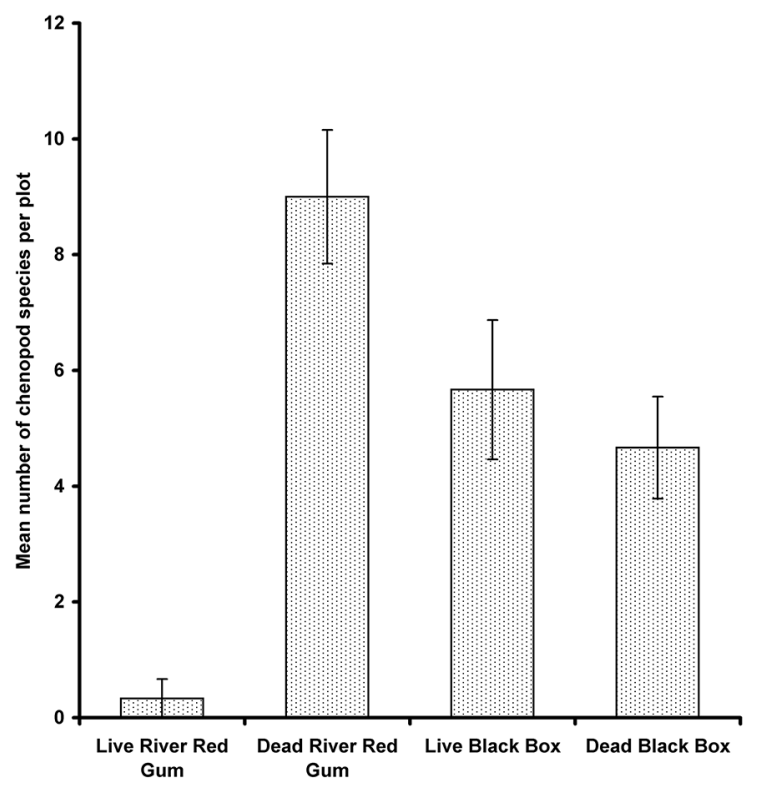

Fig. 13. Mean number of chenopod species per plot in live and dead (salt-killed) River Red Gum and Black Box stands at Dishers Creek Evaporation Basin in Section 6. Error bars are standard errors.
These results indicate that stabilisation of water levels in the lower Murray by the weir pools has impacted on the floodplain vegetation, resulting in reduced native species diversity and favouring some species and communities over others. It is likely that Communities 8 and 9, both of which are characterized by a band of Common Reed (Phragmites australis) along the water's edge, have become more extensive in the lower Murray, while Community 7, to which the riverside vegetation downstream of Lock 2 corresponds, has become less extensive.

Other studies in the South Australian reaches of the Murray have reported similar results. Walker et al. (1994) found that the distributions of aquatic and semi-aquatic plants along the margins of the Lock 2 and Lock 3 weir pools in 1988 were correlated with the amplitude of water level variations in 1982-87. Some species favoured areas below each weir where there was most variation in river levels, whereas other species favoured areas above each weir where water levels were most stable. From a broader survey of four weir pools in 1994, Blanch et al. (2000) suggested that an increase in the amplitude of river level fluctuations during low flows, from the current $10-20 \mathrm{~cm}$ range to $20-50 \mathrm{~cm}$, would reinstate water regimes suitable to the majority of species surveyed.

\section{Effects of salinisation}

Floodplain ecosystems along the Murray are increasingly threatened by rising saline groundwater caused by both large-scale irrigation farming and land clearance (Macumber 1990, Williams 2001). The problem has been compounded by river regulation reducing the frequency of high-flow, salt-flushing events (Nielsen et al. 2003) and raising water levels in the many weir pools along the river, causing nearby groundwater levels to rise (Walker et al. 1996).

The effects of salinisation on floodplain vegetation were investigated during the 1987-88 survey at Dishers Creek Evaporation Basin near Calperum in Section 6, which has been used for disposal of irrigation effluents, resulting in salinisation and extensive death of both River Red Gum and Black Box trees. Three plots were sampled in dead River Red Gum stands along Dishers Creek on the western edge of the basin, and compared with three plots in live River Red Gum stands along the Murray adjacent to the south-western edge of the basin. Three more plots were sampled in dead Black Box stands west of Dishers Creek Evaporation Basin (within $1 \mathrm{~km}$ ), and compared with three plots in live Black Box stands in the same area (apparently on slightly higher ground).

No significant effects were found on the number of native species recorded per plot. However, the mean number of exotic species per plot in dead stands $(12.0 \pm$ s.e. 1.0$)$ was significantly higher than the mean in live stands (7.1 \pm s.e. 0.9) (two-factor ANOVA, $P=0.007$, no significant difference between River Red Gum and Black Box). The mean number of chenopod species per plot (all native) was also significantly higher in dead River Red Gum stands than in live ones, but not significantly different between live 
and dead Black Box stands (Fig. 13) (two-factor ANOVA, $P=0.001$ for the interaction between the factors).

Differences in the species composition of the vegetation between live and dead stands of trees were investigated by pattern analysis. In an agglomerative hierarchical classification of the 12 plots based on their plant species composition and cover/abundance values, using the Bray and Curtis association measure and the Flexible UPGMA classification technique (PATN program), the main division was between the live River Red Gum plots and the other plots (Fig. 14). The next division was between the dead River Red Gum plots and the Black Box plots. The dead Black Box plots formed a subgroup within the Black Box group, but differences in species composition were less pronounced between live and dead Black Box plots than between live and dead River Red Gum plots (Fig. 14).

Apart from River Red Gum itself, the species most closely associated with live rather than dead River Red Gum plots (recorded in every plot in live stands but none in dead stands) were the native species Brachyscome basaltica, Centipeda cunninghamii, Eclipta platyglossa, Paspalum distichum and Phragmites australis, and the exotic species Aster subulatus and Xanthium orientale. These are all either daisies or grasses. The species most closely associated with dead River Red Gum plots were the native chenopod species Atriplex lindleyi, A. rhagodioides, Einadia nutans and Tecticornia indica, and the exotic species Heliotropium curassavicum, Hordeum murinum, Schismus barbatus and Spergularia diandra. The change in species composition in the River Red Gum plots amounted to a change from a River Red Gum community to Community 30, Muehlenbeckia florulenta Tecticornia pergranulata shrubland.

Differences in species composition between live and dead Black Box stands were less marked. The species most closely associated with live Black Box stands were Black Box itself and Enchylaena tomentosa. The species most closely associated with dead Black Box stands were Dissocarpus biflorus, Minuria cunninghamii, Wahlenbergia gracilenta and Wahlenbergia tumidifructa. All of the above are native species. There was no change in plant community. All six Black Box plots, live or dead, were classified as Community

\section{8, Eucalyptus largiflorens - Atriplex rhagodioides} woodland.

Community 30, Muehlenbeckia florulenta - Tecticornia pergranulata shrubland, was encountered at other sites beneath dead, apparently salt-killed River Red Gums, and also in saline depressions in the Black Box zone with no dead trees. As salinity levels increase beyond the tolerance of the Lignum (Muehlenbeckia florulenta), Community 30 is apparently replaced by Community 32, Tecticornia pergranulata - $T$. indica shrubland. The two samphires Tecticornia pergranulata and Tecticornia indica, are widespread native species that grow in highly saline habitats, both coastal and inland (Wilson 1980). It is likely that Community 32 occurred naturally in the most saline sites on the Murray floodplain. However, most current examples appear to have replaced other communities as a result of increasing salinisation in recent times. All five plots sampled during the 1987-88 survey had dead trees or stumps, either River Red Gum or Black Box, and two plots also had dead Lignum shrubs. Whereas Community 30 is relatively rich in species, Community 32 is one of the most species-poor communities on the Murray floodplain (Appendix 1).

Floodplain vegetation is a particularly salt-sensitive ecosystem because it occupies a low point in the landscape, where saline water tends to accumulate via both groundwater intrusion and surface flows (Hart et al. 1990, Nielsen et al. 2003). The observations made during this survey indicate a sequence of change with increasing salinisation involving death of the trees; change to a Lignum-samphire shrubland (Community 30); gradual loss of the more saltsensitive species; change to a lower, more open, much more depauperate samphire shrubland (Community 32); and, finally, complete loss of vegetation.

\section{Threatened Species and Communities}

Threatened species and communities are listed under the Commonwealth Environment Protection and Biodiversity Conservation Act 1999, the NSW Threatened Species Conservation Act 1995, the Victorian Flora and Fauna Guarantee Act 1988 and the South Australian National

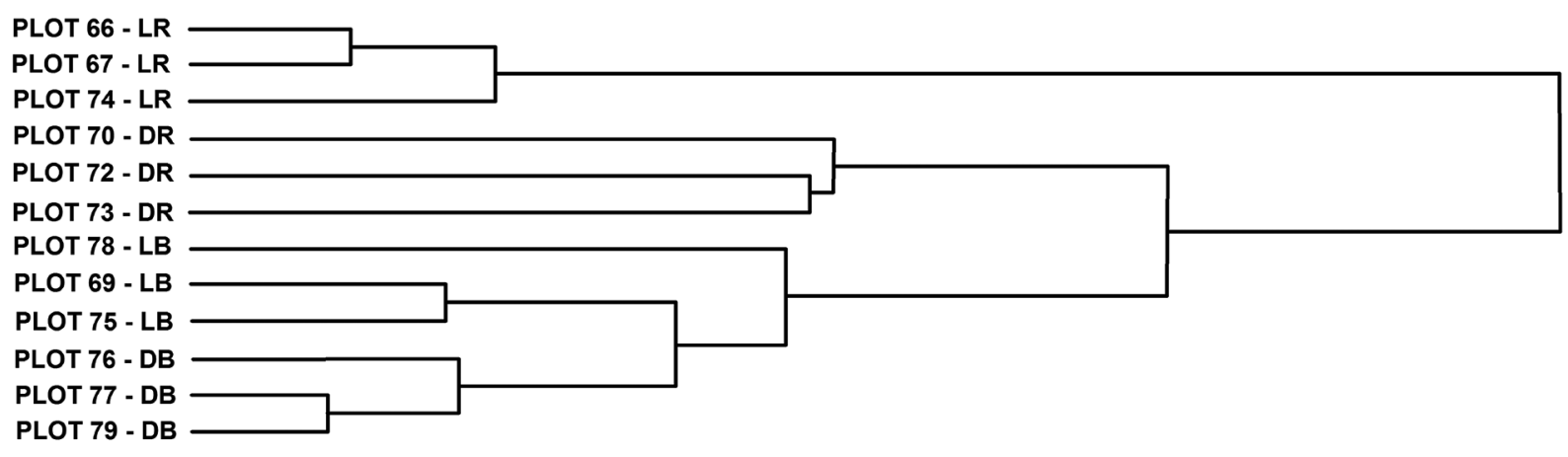

Fig. 14. Agglomerative hierarchical classification of plant species composition data from 12 sample plots at Dishers Creek Evaporation Basin in Section 6. $\mathrm{L}=$ stand of live trees, $\mathrm{D}=$ stand of dead trees (killed by salinisation), $\mathrm{R}=$ River Red Gum, B = Black Box. 
Table 2. Plant species recorded in the survey that are listed under Commonwealth or state threatened species legislation $\mathrm{E}=$ endangered, $\mathbf{R}=$ rare, $\mathbf{T}=$ threatened, $\mathrm{V}=$ vulnerable

\begin{tabular}{|c|c|}
\hline Scientific name & Common name \\
\hline Allocasuarina luehmannii & Buloke \\
\hline Amphibromus fluitans & Floating Swamp Wallaby-grass \\
\hline Atriplex limbata & Spreading Saltbush \\
\hline Atriplex rhagodioides & Silver Saltbush \\
\hline Brachyscome basaltica var. gracilis & Swamp Daisy \\
\hline Callistemon brachyandrus & Prickly Bottlebrush \\
\hline Callitriche sonderi & Matted Water Starwort \\
\hline Calocephalus sonderi & Pale Beauty-heads \\
\hline Calotis scapigera & Tufted Burr-daisy \\
\hline Crassula peduncularis & Purple Crassula \\
\hline Crassula sieberiana & Sieber's Crassula \\
\hline Cullen pallidum & Woolly Scurf-pea \\
\hline Eragrostis lacunaria & Purple Love-grass \\
\hline Exocarpos strictus & Pale-fruit Cherry \\
\hline Fimbristylis aestivalis & Summer Fringe-rush \\
\hline Glycine tabacina & Variable Glycine \\
\hline Goodenia heteromera & Spreading Goodenia \\
\hline Hakea tephrosperma & Hooked Needlewood \\
\hline Helichrysum rutidolepis & Pale Everlasting \\
\hline Isotoma fluviatilis ssp. australis & Swamp Isotome \\
\hline \multicolumn{2}{|l|}{ Juncus amabilis } \\
\hline Lobelia pratioides & Poison Lobelia \\
\hline Lomandra multiflora ssp. multiflora & Many-flower Mat-rush \\
\hline Maireana pentagona & Slender Fissure-plant \\
\hline Mentha diemenica & Slender Mint \\
\hline Muehlenbeckia horrida ssp. horrida & Spiny Lignum \\
\hline Myriophyllum crispatum & Upright Milfoil \\
\hline Nymphoides crenata & Wavy Marshwort \\
\hline Picris squarrosa & Squat Picris \\
\hline Pratia concolor & Poison Pratia \\
\hline Ranunculus inundatus & River Buttercup \\
\hline Ranunculus pumilio var. politus & Smooth-fruit Ferny Buttercup \\
\hline Rorippa laciniata & Jagged Bitter-cress \\
\hline Sclerolaena muricata var. villosa & Five-spine Bindyi \\
\hline Swainsona greyana & Hairy Darling-pea \\
\hline Swainsona phacoides & Dwarf Swainson-pea \\
\hline Viola betonicifolia ssp. betonicifolia & Showy Violet \\
\hline
\end{tabular}

Parks and Wildlife Act 1972, although the last Act only lists species, not communities.

Only one threatened species listed under Commonwealth and NSW legislation was recorded during the survey: Amphibromus fluitans (Floating Swamp Wallaby-grass). Amphibromus fluitans was recorded in two survey plots, both within Section 2 in Victoria, in Community 3, Eucalyptus camaldulensis - Poa labillardierei - Lachnagrostis filiformis open-forest. Seven species listed under Victorian legislation were recorded, but only five of these were recorded in Victoria (Table 2). Thirty species listed under South Australian legislation were recorded, but only 11 of these were recorded in South Australia (Table 2).

Five of the Murray vegetation communities recognized in this survey correspond to threatened communities listed under Commonwealth or State legislation (Table 3). These

\begin{tabular}{|c|c|c|c|c|c|c|}
\hline \multicolumn{4}{|c|}{ Threatened species listing } & \multicolumn{3}{|c|}{ Survey records } \\
\hline \multirow[t]{2}{*}{ Cmwlth } & NSW & Vic & SA & NSW & Vic & SA \\
\hline & & $\mathrm{T}$ & & $\mathrm{X}$ & & \\
\hline \multirow[t]{36}{*}{ V } & $\mathrm{V}$ & & & & $\mathrm{X}$ & \\
\hline & & $\mathrm{T}$ & & & $\mathrm{X}$ & \\
\hline & & $\mathrm{T}$ & & & $\mathrm{X}$ & $\mathrm{X}$ \\
\hline & & & $\mathrm{R}$ & $\mathrm{X}$ & $\mathrm{X}$ & $\mathrm{X}$ \\
\hline & & & $\mathrm{R}$ & & & $\mathrm{X}$ \\
\hline & & & $\mathrm{R}$ & $\mathrm{X}$ & & \\
\hline & & & $\mathrm{R}$ & $\mathrm{X}$ & $\mathrm{X}$ & $\mathrm{X}$ \\
\hline & & & $\mathrm{R}$ & $\mathrm{X}$ & $\mathrm{X}$ & $\mathrm{X}$ \\
\hline & & & $\mathrm{R}$ & & $\mathrm{X}$ & \\
\hline & & & $\mathrm{E}$ & $\mathrm{X}$ & $\mathrm{X}$ & $\mathrm{X}$ \\
\hline & & $\mathrm{T}$ & & & $\mathrm{X}$ & \\
\hline & & & $\mathrm{R}$ & & $\mathrm{X}$ & $\mathrm{X}$ \\
\hline & & & $\mathrm{R}$ & $\mathrm{X}$ & $\mathrm{X}$ & \\
\hline & & & $\mathrm{R}$ & $\mathrm{X}$ & & \\
\hline & & & $\mathrm{V}$ & $\mathrm{X}$ & & \\
\hline & & & $\mathrm{R}$ & & $\mathrm{X}$ & \\
\hline & & & $\mathrm{R}$ & $\mathrm{X}$ & & \\
\hline & & & E & & $\mathrm{X}$ & \\
\hline & & & $\mathrm{R}$ & $\mathrm{X}$ & $\mathrm{X}$ & \\
\hline & & & $\mathrm{V}$ & $\mathrm{X}$ & $\mathrm{X}$ & \\
\hline & & & $\mathrm{R}$ & $\mathrm{X}$ & & \\
\hline & & & E & $\mathrm{X}$ & & \\
\hline & & & $\mathrm{R}$ & & $\mathrm{X}$ & $\mathrm{X}$ \\
\hline & & & $\mathrm{R}$ & & $\mathrm{X}$ & \\
\hline & & & $\mathrm{R}$ & & & $\mathrm{X}$ \\
\hline & & & $\mathrm{V}$ & $\mathrm{X}$ & $\mathrm{X}$ & \\
\hline & & $\mathrm{T}$ & $\mathrm{R}$ & $\mathrm{X}$ & $\mathrm{X}$ & \\
\hline & & & $\mathrm{R}$ & $\mathrm{X}$ & $\mathrm{X}$ & $\mathrm{X}$ \\
\hline & & & $\mathrm{R}$ & $\mathrm{X}$ & $\mathrm{X}$ & $\mathrm{X}$ \\
\hline & & & $\mathrm{R}$ & $\mathrm{X}$ & $\mathrm{X}$ & \\
\hline & & & $\mathrm{V}$ & & $\mathrm{X}$ & \\
\hline & & & $\mathrm{R}$ & $\mathrm{X}$ & $\mathrm{X}$ & \\
\hline & & & $\mathrm{R}$ & $\mathrm{X}$ & $\mathrm{X}$ & $\mathrm{x}$ \\
\hline & & $\mathrm{T}$ & & & & $\mathrm{X}$ \\
\hline & & $\mathrm{T}$ & & & $\mathrm{X}$ & \\
\hline & & & E & $\mathrm{X}$ & $\mathrm{X}$ & \\
\hline
\end{tabular}

include all four of the communities associated with rises within the floodplain. The fifth community, Community 25, Eucalyptus largiflorens - Melaleuca lanceolata Allocasuarina luehmannii woodland, occurs in the Black Box zone in Section 4, but is a marginal floodplain remnant of an Allocasuarina luehmannii (Buloke) community that originally occurred on the adjacent rise, where it has now been cleared except for a few remnant Buloke trees.

Thus, all five of the Murray communities considered threatened under the legislation are essentially communities of the rises rather than the floodplain itself. None of the listed communities is restricted to the Murray floodplain - all occur beyond the Murray. However, there was a recent nomination to list the River Murray and associated wetlands, floodplains and groundwater ecosystems, from the junction of the Darling River to the sea, as a threatened ecological community under 


\section{Table 3. Murray vegetation communities that are listed under Commonwealth or state threatened species legislation}

Threatened communities are not listed under South Australian legislation. $\mathrm{C}=$ critically endangered ecological community, $\mathrm{E}=$ endangered ecological community, $\mathrm{T}=$ threatened community

\section{Murray community}

25. Eucalyptus largiflorensMelaleuca lanceolata-Allocasuarin luehmannii woodland

\section{Eucalyptus microcarpa open-} forest

\section{Commonwealth}

Buloke Woodlands of the Riverina and Murray-Darling Depression Bioregion (E)

Grey Box (Eucalyptus microcarpa) Grassy Woodlands and Derived Native Grasslands of South-eastern Australia (E)

\section{Threatened community listings} New South Wales

Allocasuarina luehmannii Woodland in the Riverina and Murray-Darling Depression Bioregions (E)

Inland Grey Box Woodland in the Riverina, NSW South Western Slopes, Cobar Peneplain, Nandewar and Brigalow Belt South Bioregions (E)

35. Eucalyptus melliodora woodland White Box-Yellow Box-Blakely’s Red White Box Yellow Box Blakely's Red Gum Grassy Woodland and Derived Gum Woodland (E)

36. Callitris glaucophylla woodland

37. Dodonaea viscosa-Callitris gracilis shrubland

Sandhill Pine Woodland in the Riverina, Semi-arid Herbaceous Murray-Darling Depression and NSW Pine Woodland South Western Slopes Bioregions (E) Community (T)
Commonwealth legislation. The nomination was assessed by the Threatened Species Scientific Committee (2014), who concluded that it was eligible for listing as critically endangered. This part of the river system was accordingly listed as a critically endangered ecological community in August 2013. However, following objections from the farming sector and a change of government, its listing was disallowed by Federal Parliament in December 2013.

\section{Conclusions}

The present study is the first to describe floristic patterns in the floodplain vegetation of the River Murray at a broad scale, covering most of the length of the river, including the Edward-Wakool anabranch system. 37 plant communities were distinguished between Hume Dam and Lake Alexandrina, not including the vegetation of permanent wetlands and cleared areas. This represents much greater variation than might be expected from the uniformity of the tree layer, which is dominated by just two species, River Red Gum (Eucalyptus camaldulensis) and Black Box (Eucalyptus largiflorens). 21 communities were distinguished in the River Red Gum zone, which borders the river throughout the survey area. 12 communities were distinguished in the Black Box zone, which is associated with the less frequently flooded parts of the floodplain in the semi-arid reaches of the river, from the upper Murray-Edward junction downstream to Mannum. The other four communities were associated with rises within the floodplain that are rarely if ever flooded and support non-floodplain vegetation similar to that found on similar soils outside the floodplain.

Variation at the community level occurs both along the river and across the floodplain. The main floristic division among the River Red Gum communities was between Riverine Plain/Headwaters Zone communities of the upper Murray, and Mallee Zone communities of the lower Murray. Among the Black Box communities, the main floristic division was between inner floodplain communities and outer floodplain communities, with a further division between South Australian communities and New South Wales/Victorian communities. Major factors influencing the floristic patterns included flooding frequency/duration and soil salinity.

The changing floristic composion of the understorey vegetation along the river was reflected in the distribution of individual plant species. A total of 499 species, subspecies and varieties of plants (316 native and 183 exotic) were recorded in the 335 survey plots. Of these, apart from River Red Gum itself, only 12 species were recorded in every river section. Most species had a much more restricted distribution, reflecting the changes in climate, geomorphology and soils along the river.

The study provides critical evidence of the condition of the Murray floodplain vegetation in the 1980s, before the compounding effects of the severe and prolonged Millenium Drought in south-eastern Australia from 1997 to 2010. Tree health was poor even before the drought. It was best at the upper end of the river, where $84 \%$ of trees were assessed as healthy, and became steadily worse downstream, being poorest in the lower reaches below the Darling Junction, where only $60 \%$ of trees were assessed as healthy (and the criterion for 'healthy' was a broad one - less than $40 \%$ of the crown dead). Obvious causes of tree death in the lower reaches were soil salinisation and inundation of eucalypt stands by raised water levels upstream of weirs. However, while some low-lying sites have become wetter, tree health has been affected more widely because the lower Murray floodplain in general has become drier as a result of the high level of water extraction, mainly for irrigation, throughout the Murray-Darling Basin. This has meant fewer, less extensive, less sustained floods, an effect that is most 
pronounced in the lower reaches of the river (Walker and Thoms 1993, Maheshwari et al. 1995, Dyer 2002, Roberts 2004, CSIRO 2008). Reduced flooding has also meant less effective leaching of salt from floodplain soils in the lower Murray. Consistent with these effects, the condition of Black Box trees was found to be significantly worse in 1987-88 than the condition of River Red Gum trees (71\% of River Red Gum trees assessed as healthy, compared with only $56 \%$ of Black Box trees).

The situation was exacerbated during the Millenium Drought, when overbank flows were largely absent along the lower Murray between 1994 and 2010 (Holland et al. 2013). Surveys in 2002-04 found poor River Red Gum and Black Box health (Murray-Darling Basin Commission 2003, Smith and Kenny 2005, Brett Lane and Associates 2005), and indicated a decline in tree health since our 1987-88 survey. Tree health deteriorated further as the drought continued. Cunningham et al. (2009) assessed that $72 \%$ of River Red Gum stands, and $92 \%$ of Black Box stands along the river were in a stressed condition in 2009 , and that the extent of stressed stands had been $66 \%$ lower in 2003 . The situation was worse in the Mallee Zone than in the Riverine Plain. Following the breaking of the drought with a major flood over the summer of 2010-11, a significant improvement in the condition of both River Red Gum and Black Box trees was reported at several sites along the Murray in 2012 (Bennetts and Jolly 2012, Henderson et al. 2012a, 2012b).

More recent surveys of vegetation condition imply that the decline in tree health along the Murray has mainly occurred during the drought. The Murray-Darling Basin Commission (2003) reported a severe decline in tree health in the 12 months prior to their February 2003 survey. Brett Lane and Associates (2005) reported a severe decline in tree health between 2002 and 2004. Cunningham et al. (2009) reported a severe decline between 2003 and 2009. The results from our 1987-88 survey are important because they show that poor tree health was already evident before the drought, and was a serious concern even without the compounding effects of the drought. The patterns that we found in 1987-88 poorer tree health in the lower reaches of the river below the Darling Junction, and poorer tree health for Black Box than for River Red Gum - were the same patterns as subsequently reported during the drought.

A further indicator of vegetation health available from the 1987-88 survey was the density of eucalypt regeneration. Like the health of the trees themselves, regeneration was poorest in the lower Murray below the Darling Junction, and Black Box regeneration was much sparser overall than River Red Gum regeneration. The poor eucalypt regeneration in the lower Murray is due to a combination of factors, including reduced flooding, increasing salinisation, overgrazing and less post-logging regeneration. Coupled with the poor condition of the Black Box trees, the poor regeneration of Black Box suggests that its long-term future along the Murray, particularly below the Darling Junction, is tenuous, even though it is a dominant component of the vegetation.
The findings of poor tree health and sparse regeneration below the Darling Junction coincide with the most heavily regulated part of the River Murray, where the reduction in flooding due to upstream storages and water extraction has been greatest (Walker and Thoms 1993, Maheshwari et al. 1995, Dyer 2002). Reduced flooding, which means not only less water for the trees but also less flushing of accumulated salt from the saline Mallee Zone floodplain, is implicated as the primary cause of the observed decline of River Red Gum and Black Box on the lower Murray.

Another indicator of vegetation health is the extent of weed invasion. The integrity of the floodplain vegetation of the Murray has been severely compromised by weed invasion, but this problem has received relatively little attention in recent reviews (Roberts 2004, Jensen and Walker 2012). Exotic species comprised $37 \%$ of all species recorded in our survey plots. Weeds were common throughout the survey area, but were most prevalent in the climatically wetter sections of the river, both at the downstream end (below Mannum) and at the upstream end (above Tocumwal). The mean number of exotic species per plot equalled or exceeded the number of native species in these sections of the river, whereas native species outnumbered exotic species in the other river sections. Communities of the River Red Gum zone and the rises were generally weedier than those of the Black Box zone. Exotic species strongly influenced the community classification. They were the dominant overstorey species in two communities (willows Salix species) and outnumbered native species in the understorey of another eight communities. At the lower end of the river, below Mannum, the River Red Gums that originally fringed the river have been mostly replaced by dense thickets of the exotic Weeping Willow (Salix babylonica).

Other factors that have impacted on the floodplain vegetation at the community level have been river regulation and soil salinisation. Stabilization of water levels in the lower Murray by construction of a series of weirs and barrages has favoured the spread of some communities at the expense of others. The favoured communities, Communities 8 and 9, which are characterized by stands of Common Reeds (Phragmites australis) along the water's edge, appear to be artefacts of river regulation. Salinisation has also brought about community changes, resulting in death of eucalypts and replacement of eucalypt communities by shrub communities dominated by samphires Tecticornia species (Communities 30 and 32). The samphire community characteristic of the most saline sites (Community 32) is one of the most speciespoor communities on the Murray floodplain.

Logging along the Murray in New South Wales and Victoria has resulted in extensive replacement of old growth River Red Gum forests and woodlands by more even-aged stands of straight young trees (Mac Nally et al. 2011). Forest structure prior to European settlement is thought to have consisted of large old widely-spreading trees interspersed with a mosaic of mixed-age stands of varying sizes (Jacobs 1955). Following the recent conversion of many areas of 
State Forest along the Murray in both New South Wales and Victoria to National Park or Regional Park, and thus the cessation of logging in these areas, they should now revert gradually to mature forest and woodland.

The River Murray and associated wetlands, floodplains and groundwater ecosystems from the junction of the Darling River to the sea were recently nominated for listing as a threatened ecological community under Commonwealth legislation. Following a detailed assessment, the Threatened Species Scientific Committee (2014) concluded that this part of the river system was eligible for listing as critically endangered. It was accordingly listed as a critically endangered ecological community in August 2013. However, following objections from the farming sector and a change of government, its listing was disallowed by Federal Parliament in December 2013, which was an unprecedented rejection of the advice of the Threatened Species Scientific Committee.

The results of the 1987-88 survey support the Threatened Species Scientific Committee's (2014) assessment that the floodplain vegetation along the lower Murray below the Darling Junction is severely degraded and warrants listing as a critically endangered ecological community. Furthermore, the results show that the deteriorating condition of the vegetation was already evident in the 1980s and, although exacerbated by the subsequent Millenium Drought, it is not just a consequence of that drought. The results are consistent with the conclusion that the primary cause of the decline has been river regulation and water extraction for irrigation. The air photo mapping study carried out in parallel with our field survey confirmed that extensive vegetation degradation was evident along the Murray before the drought and was worse in the Mallee Zone than on the Riverine Plain (Margules and Partners et al. 1990). The rate of deterioration has increased rapidly since the 1980s and although there has been some improvement since the breaking of the drought, the poor condition of the River Murray floodplain vegetation, an Australian icon, remains a major conservation and management issue. The impacts of climate change - higher temperatures and reduced rainfall - have compounded the problem (Cai and Cowan 2008a, 2008b, Cai et al. 2009, Mac Nally et al. 2011) and will continue to do so at an increasing rate.

\section{Acknowledgements}

This study was commissioned by the then Murray-Darling Basin Commission as part of the River Murray Vegetation Study. Information and assistance was provided by many people. Special thanks go to Doug Parsonson from Margules and Partners, and Peter Woodgate from the then Victorian Department of Conservation, Forests and Lands. We also thank the members of the steering committee, which included Norm Mackay, Jacki Venning, Jenny Lopez, Marilyn Fox, Paul Gullan and Bob Pressey. The National Herbarium of NSW kindly provided computer facilities for the floristic analysis. We are also grateful for the helpful comments of an anonymous referee.

\section{References}

Ashwell, D. (1987). Floodplain Vegetation of the Lower Murray River - the Victorian Mallee Region. Land Conservation Council, Melbourne.

Beadle, N.C.W. (1948). The Vegetation and Pastures of Western New South Wales. Government Printer, Sydney.

Beadle, N.C.W. (1981). The Vegetation of Australia. Cambridge University Press, Cambridge.

Bennetts, K. and Jolly, K. (2012). Gunbower Forest TLM stand and tree condition assessments 2012. Report for Victorian North Central Catchment Management Authority. Fire, Flood and Flora, Cape Woolamai, Victoria.

Benson, J.S. (2008). New South Wales Vegetation Classification and Assessment: Part 2 Plant communities of the NSW Southwestern Slopes Bioregion and update of NSW Western Plains plant communities, Version 2 of the NSWVCA database. Cunninghamia 10: 599-673.

Benson, J.S., Allen, C.B., Togher, C. and Lemmon, J. (2006). New South Wales Vegetation Classification and Assessment: Part 1 Plant communities of the NSW Western Plains. Cunninghamia 9: 383-450.

Blanch, S.J., Walker, K.F. and Granf, G.G. (2000). Water regimes and littoral plants in four weir pools of the River Murray, Australia. Regulated Rivers: Research and Management 16: 445-456.

Boulos, L. (1973). Revision systematique du genre Sonchus L. s.l. IV. Sous-genre 1. Sonchus. Botaniska Notiser 126: 155-196.

Bowler, J. (1978). Quaternary climate and tectonics in the evolution of the Riverine Plain, southeastern Australia. Pp. 70-112 in J.L. Davies and M.A.J. Williams (eds) Landform Evolution in Australasia. Australian National University Press, Canberra.

Bowler, J.M. and Magee, J.W. (1978). Geomorphology of the Mallee Region in semi-arid northern Victoria and western New South Wales. Proceedings of the Royal Society of Victoria 90: $5-21$.

Bren, L.J. (1988). Flooding characteristics of a riparian red gum forest. Australian Forestry 51: 57-62.

Bren, L.J. (1992). Tree invasion of an intermittent wetland in relation to changes in flooding frequency of the River Murray, Australia. Australian Journal of Ecology 17: 395-408.

Bren, L.J. and Gibbs, N.L. (1986). Relationships between flood frequency, vegetation and topography in a river red gum forest. Australian Forest Research Newsletter 16: 357-370.

Brett Lane and Associates (2005). Survey of River Red Gum and Black Box Health along the River Murray in New South Wales, Victoria and South Australia - 2004. Murray-Darling Basin Commission, Canberra. 
Butler, B.E., Blackburn, G., Bowler, J.M., Lawrence, C.R., Newell, J.W. and Pels, S. (1973). A Geomorphic Map of the Riverine Plain of South-eastern Australia. Australian National University Press, Canberra.

Cai, W. and Cowan, T. (2008a). Evidence of impacts from rising temperature on inflows to the Murray-Darling Basin. Geophysical Research Letters 35: L07701.

Cai, W. and Cowan, T. (2008b). Dynamics of late autumn rainfall reduction over southeastern Australia. Geophysical Research Letters 35: L09708.

Cai, W., Cowan, T., Briggs, P. and Raupach, M. (2009). Rising temperature depletes soil moisture and exacerbates severe drought conditions across southeast Australia. Geophysical Research Letters 36: L21709.

Catford, J.A., Downes, B.J., Gippel, C.J. and Vesk, P.A. (2011). Flow regulation reduces native plant cover and facilitates exotic invasion in riparian wetlands. Journal of Applied Ecology 48: 432-442.

Chesterfield, E.A. (1986). Changes in the vegetation of the river red gum forest at Barmah, Victoria. Australian Forestry 49: 4-15.

Chesterfield, E.A., Loyn, R.H. and Macfarlane, M.A. (1984). Flora and Fauna of Barmah State Forest and their Management. Research Branch Report 240. Forests Commission, Victoria.

Chettle, T. (1959). Some problems associated with grazing in the Murray River areas. Technical Papers 1: 3-7. Forests Commission, Victoria.

Close, A. (1990). The impact of man on the natural flow regime. Pp. 60-74 in N. Mackay and D. Eastburn (eds) The Murray. Murray-Darling Basin Commission, Canberra.

Commonwealth of Australia (2012). Water Act 2007 Basin Plan, November 2012. Commonwealth of Australia, Canberra.

Cosier, P., Davis, R., Flannery, T., Harding, R., Hughes, L., Karoly, D., Possingham, H., Purves, R., Saunders, D., Thom, B. and Williams, J. (2012). Does a 3,200Gl reduction in extractions combined with the relaxation of eight constraints give a healthy working Murray-Darling Basin river system? Wentworth Group of Concerned Scientists, Sydney.

Craig, A.E., Walker, K.F. and Boulton, A.J. (1991). Effects of edaphic factors and flood frequency on the abundance of lignum (Muehlenbeckia florulenta Meissner) (Polygonaceae) on the River Murray floodplain, South Australia. Australian Journal of Botany 39: 431-443.

CSIRO (2008). Water Availability in the Murray-Darling Basin: A Report to the Australian Government. Commonwealth Scientific and Industrial Research Organisation, Canberra.

Cunningham, G.M., Mulham, W.E., Milthorpe, P.L. and Leigh, J.H. (1981). Plants of Western New South Wales. Government Printer, Sydney.

Cunningham, S.C., Mac Nally, R., Griffioen, P. and White, M. (2009). Mapping the Condition of River Red Gum and Black Box Stands in The Living Murray Icon Sites: Stand Condition Report 2009 (with modelled results for 2003 and 2008). Murray-Darling Basin Authority, Canberra.

Cunningham, S.C., Thomson, J.R., Mac Nally, R., Read, J. and Baker, P.J. (2011). Groundwater change forecasts widespread forest dieback across an extensive floodplain system. Freshwater Biology 56: 1494-1508.

Davies, P.E., Harris, J.H., Hillman, T.J. and Walker, K.F. (2008). SRA Report 1: A Report on the Ecological Health of Rivers in the Murray-Darling Basin, 2004-2007. Report by Independent Sustainable Rivers Audit Group for Murray-Darling Basin Ministerial Council. Murray-Darling Basin Commission, Canberra.

De Waal, L., Child, L.E., Wade, P.M. and Brock, J. H. (eds) (1994). Ecology and Management of Invasive Riverside Plants. John Wiley and Sons, New York.
Dexter, B.D. (1967). Flooding and Regeneration of River Red Gum, Eucalyptus camaldulensis Dehn. Bulletin 20. Forests Commission, Victoria.

Dexter, B.D. (1978). Silviculture of the River Red Gum forests of the Central Murray floodplain. Proceedings of the Royal Society of Victoria 90: 175-191.

Dexter, B.D., Rose, H.J. and Davies, N. (1986). River regulation and associated forest management problems in the River Murray red gum forests. Australian Forestry 49: 16-27.

Duncan, D., Moxham, C. and Read, C. (2007). Effect of Stock Removal on Woodlands in the Murray Mallee and Wimmera Bioregions of Victoria. Department of Sustainability and Environment, Melbourne.

Dyer, F.J. (2002). Assessing the hydrological changes to flood plain wetland inundation caused by river regulation. Pp. 245-254 in F.J. Dyer, M.C. Thoms and J.M. Olley (eds) The Structure, Function and Management Implications of Fluvial Sedimentary Systems. IAHS Publication 276. International Association of Hydrological Sciences, Wallingford, UK.

Eldridge, S.R., Thorburn, P.J., McEwan, K.L. and Hatton, T.J. (1993). Health and Structure of Eucalyptus Communities on Chowilla and Monoman Islands of the River Murray Floodplain, South Australia. Divisional Report 93/3. CSIRO Division of Water Resources, Canberra.

Fox, M.D. (1991). The natural vegetation of the Ana Branch-Mildura 1:250 000 map sheet (New South Wales). Cunninghamia 2: 443-493.

Frith, H.J. and Sawer, G. (eds) (1974). The Murray Waters: Man, Nature and a River System. Angus and Robertson, Sydney.

Frood, D. (1983). The Vegetation of the Murray Valley Study Area. Land Conservation Council, Melbourne.

Gauch, H.G. (1979). COMPCLUS: A FORTRAN Program for Rapid Initial Clustering of Large Data Sets. Cornell University, Ithaca, New York.

Gauch, H.G. (1980). Rapid initial clustering of large data sets. Vegetatio 42: 103-111.

Gauch, H.G. and Whittaker, R.H. (1981). Hierarchical classification of community data. Journal of Ecology 69: 135-152.

Gehrke, P., Gawne, B. and Cullen, P. (2003). What is the Status of River Health in the Murray-Darling Basin? CSIRO Land and Water, Canberra.

George, A.K., Walker, K.F. and Lewis, M.M. (2005). Population status of eucalypt trees on the River Murray floodplain, South Australia. River Research and Applications 21: 271-282.

Gippel, C.J. and Blackham, D. (2002). Review of Environmental Impacts of Flow Regulation and Other Water Resource Developments in the River Murray and Lower Darling River Systems. Report by Fluvial Systems Pty Ltd for Murray-Darling Basin Commission, Canberra.

Harris, J.A. (1986). Defoliation of River Red Gums by Gum Leaf Skeletoniser. State Notes from the Von Mueller Institute 1. Forests and Lands Service, Victoria.

Harris, J.A., Neumann, F.G. and Ward, B. (1977). An Outbreak of the Gum Leaf Skeletoniser, Uraba lugens Walker, in River Red Gum Forest near Barmah. Research Branch Report 87. Forests Commission, Victoria.

Hart, B.T., Bailey, P., Edwards, R., Hortle, K., James, K., McMahon, A., Meredith, C. and Swadling, K. (1990). Effects of salinity on river, stream and wetland ecosystems in Victoria, Australia. Water Research 24: 1103-1117.

Henderson, M., Wood, D., Cranston, G., Hayward, G., Campbell, C., Johns, C. and Vilizzi, L. (2012a). The Living Murray condition monitoring at Hattah Lakes 2011/12. Report for Victorian Mallee Catchment Management Authority. MurrayDarling Freshwater Research Centre, Mildura. 
Henderson, M., Wood, D., Cranston, G., Vilizzi, L., Campbell, C. and Johns, C. (2012b). The Living Murray condition monitoring at Lindsay, Mulcra and Wallpolla Islands 2011/12. Report for Victorian Mallee Catchment Management Authority. MurrayDarling Freshwater Research Centre, Mildura.

Hill, M.O. (1979a). TWINSPAN: A FORTRAN Program for Arranging Multivariate Data in an Ordered Two-way Table by Classification of the Individuals and Attributes. Cornell University, Ithaca, New York.

Hill, M.O. (1979b). DECORANA: A FORTRAN Program for Detrended Correspondence Analysis and Reciprocal Averaging. Cornell University, Ithaca, New York.

Hill, M.O. and Gauch, H.G. (1980). Detrended correspondence analysis, an improved ordination technique. Vegetatio 42: 4758.

Holland, K.L., Turnadge, C.J., Nicol, J.M., Gehrig, S.L. and Strawbridge, A.D. (2013). Floodplain Response and Recovery: Comparison between Natural and Artificial Floods. Technical Report Series No. 13/4. Goyder Institute for Water Research, Adelaide.

Hood, W.G. and Naiman, R.J. (2000). Vulnerability of riparian zones to invasion by exotic vascular plants. Plant Ecology 148 : $105-114$.

Jacobs, M.R. (1955). Growth Habits of the Eucalypts. Forestry and Timber Bureau, Canberra.

Jacobs, T. (1990). River regulation. Pp. 38-58 in N. Mackay and D. Eastburn (eds) The Murray. Murray-Darling Basin Commission, Canberra.

Jansen, A. and Robertson, A.I. (2001). Relationships between livestock management and the ecological condition of riparian habitats along an Australian floodplain river. Journal of Applied Ecology 38: 63-75.

Jensen, A.E. and Walker, K.F. (2012). A river in crisis: the Lower River Murray, Australia. Pp. 357-369 in P.J. Boon and P.J. Raven (eds) River Conservation and Management. John Wiley and Sons, Chichester, UK.

Jolly, I.D. (1996). The effects of river management on the hydrology and hydroecology of arid and semi-arid floodplains. Pp. 577-609 in M.G. Anderson, D.E. Walling and P.D. Bates (eds) Floodplain Processes. John Wiley and Sons, Chichester, New York.

Jolly, I.D., Walker, G.R. and Thorburn, P.J. (1993). Salt accumulation in semi-arid floodplain soils with implications for forest health. Journal of Hydrology 150: 589-614.

Jolly, I.D., Walker, G.R., Hollingsworth, I.D., Eldridge, S.R., Thorburn, P.J., McEwan, K.L. and Hatton, T.J. (1996). The causes of decline in eucalypt communities and possible ameliorative approaches. Pp. 119-138 in G.R. Walker, I.D. Jolly and S.D. Jarwal (eds) Salt and Water Movement in the Chowilla Floodplain. Water Resources Series No. 15. CSIRO Division of Water Resources, Canberra.

Kiddle, G. (1987). River Red Gum (Eucalyptus camaldulensis) Regeneration along the River Murray in South Australia. South Australian Department of Environment and Planning, Adelaide.

Kingsford, R.T. (2000). Ecological impacts of dams, water diversions and river management on floodplain wetlands in Australia. Austral Ecology 25: 109-127.

Mackay, N. and Eastburn, D. (eds) (1990). The Murray. MurrayDarling Basin Commission, Canberra.

Mac Nally, R., Cunningham, S.C., Baker, P.J., Horner, G.J. and Thomson, J.R. (2011). Dynamics of Murray-Darling floodplain forests under multiple stressors: the past, present and future of an Australian icon. Water Resources Research 47: W00G05.

Macumber, P. (1990). The salinity problem. Pp. $110-125$ in N. Mackay and D. Eastburn (eds) The Murray. Murray-Darling Basin Commission, Canberra.
Maheshwari, B.L., Walker, K.F. and McMahon, T.A. (1995). Effects of flow regulation on the flow regime of the River Murray, Australia. Regulated Rivers: Research and Management 10: $15-38$.

Margules and Partners, P \& J Smith Ecological Consultants and Department of Conservation, Forests and Lands Victoria (1990). River Murray Riparian Vegetation Study. MurrayDarling Basin Commission, Canberra.

Murphy, B.F. and Timbal, B. (2007). A review of recent climate variability and climate change in southeastern Australia. International Journal of Climatology 28: 859-879.

Murray-Darling Basin Authority (2011). The Living Murray StoryOne of Australia's Largest River Restoration Projects. MurrayDarling Basin Authority, Canberra.

Murray-Darling Basin Commission (2003). Preliminary Investigations into Observed River Red Gum Decline along the River Murray below Euston. Technical Report 03/03. MurrayDarling Basin Commission, Canberra.

National Climate Centre (2010). Special Climate Statement 22: Australia's wettest September on record but it is not enough to clear long-term rainfall deficits. Bureau of Meteorology, Australian Government, Melbourne.

Nielsen, D.L., Brock, M.A., Rees, G.N. and Baldwin, D.S. (2003). Effects of increasing salinity on freshwater ecosystems in Australia. Australian Journal of Botany 51: 655-665.

Nix, H.A. and Kalma, J.D. (1982). The climate of the MurrayDarling Basin. Pp. 22-38 in Murray-Darling Basin Project Development Study Stage 1 Working Papers. CSIRO Division of Land and Water Resources, Canberra.

Overton, I.C., Jolly, I.D., Slavich, P.G., Lewis, M.M. and Walker, G.R. (2006). Modelling vegetation health from the interaction of saline groundwater and flooding on the Chowilla floodplain, South Australia. Australian Journal of Botany 54: 207-220.

Porteners, M.F. (1993). The natural vegetation of the Hay Plain: Booligal-Hay and Deniliquin-Bendigo 1:250 000 maps. Cunninghamia 3: 1-122.

Pressey, R.L. (1986). Wetlands of the River Murray. River Murray Commission, Canberra.

Roberts, J. (2004). Floodplain Forests and Woodlands in the Southern Murray-Darling Basin. Report JR 03/2004. Australian Conservation Foundation, Canberra.

Roberts, J. and Ludwig, J.A. (1990). Riparian habitats on the Chowilla floodplain of the River Murray, South Australia. Wetlands (Australia) 9: 13-19.

Robertson, A.I. and Rowling, R.W. (2000). Effects of livestock on riparian zone vegetation in an Australian dryland river. Regulated Rivers: Research and Management 16: 527-541.

Scott, J.A. (1992). The natural vegetation of the Balranald-Swan Hill area. Cunninghamia 2: 597-652.

Smith, F.M. and Kenny, S.K. (2005). Floristic Vegetation and Tree Health Mapping, River Murray Floodplain, South Australia. Department for Environment and Heritage, Adelaide.

Smith, P. and Smith, J. (1990). Floodplain vegetation Pp. 214-228 in N. Mackay and D. Eastburn (eds) The Murray. MurrayDarling Basin Commission, Canberra.

Smith, R., Herriot, R.I. and Johnston, E.J. (1943). The Soil and Land-use Survey of the Wakool Irrigation District, New South Wales. Bulletin 162. Council for Scientific and Industrial Research, Australia.

Stokes, K., Ward, K. and Colloff, M. (2010). Alterations in flood frequency increase exotic and native species richness of understorey vegetation in a temperate floodplain eucalypt forest. Plant Ecology 211: 219-233.

Storrier, R.R. and Kelly, I.D. (eds) (1978). Hydrogeology of the Riverine Plain of South Eastern Australia. Australian Society of Soil Science, Wagga Wagga. 
Storrier, R.R. and Stannard, M.E. (eds) (1980). Aeolian Landscapes in the Semi-arid Zone of South Eastern Australia. Australian Society of Soil Science, Wagga Wagga.

Taylor, P.J., Walker, G.R., Hodgson, G., Hatton, T.J. and Correll, R.L. (1996). Testing of a GIS model of Eucalyptus largiflorens health on a semiarid, saline floodplain. Environmental Management 20: 553-564.

Thompson, M.B. (1986). River Murray Wetlands: Their Characteristics, Significance and Management. South Australian Department of Environment and Planning/Nature Conservation Society of South Australia, Adelaide.

Thoms, M.C., Suter, P., Roberts, J., Koehn, J., Jones, G., Hillman, T. and Close, A. (2000). Report of the River Murray Scientific Panel on Environmental Flows: River Murray - Dartmouth to Wellington and the Lower Darling River. River Murray Scientific Panel on Environmental Flows, Murray-Darling Basin Commission, Canberra.

Thorburn, P.J. and Walker, G.R. (1994). Reliance of creek-side river red gums on creek water. Australian Journal of Marine and Freshwater Research 45: 1439-1443.

Threatened Species Scientific Committee (2014). Threatened Species Scientific Committee's Advice for the River Murray and associated wetlands, floodplains and groundwater systems, from the junction with the Darling River to the sea. Prepared for the Commonwealth Minister for the Environment, Heritage and Water. Threatened Species Scientific Committee, Canberra.

Treloar, G.K. (1959). Some factors affecting seedling survival of Eucalyptus largiflorens F. Muell. Australian Forestry 23: 4648.

Van der Sommen, F.J. (1987). A Study of Components and Processes Influencing the Ecological Status of Riparian Vegetation of the River Murray Floodplain in South Australia. South Australian Department of Environment and Planning, Adelaide.
Venning, J. (1984). Regeneration of Riparian Vegetation along the River Murray. South Australian Department of Environment and Planning, Adelaide.

Waisel, Y. (1972). The Biology of Halophytes. Academic Press, New York.

Walker, G.R., Jolly, I.D. and Jarwal, S.D. (eds) (1996). Salt and Water Movement in the Chowilla Floodplain. Water Resources Series No. 15. CSIRO Division of Water Resources, Canberra.

Walker, K.F., Boulton, A.J., Thoms, M.C. and Sheldon, F. (1994). Effects of water-level changes induced by weirs on the distribution of littoral plants along the River Murray, South Australia. Australian Journal of Marine and Freshwater Research 45: 1421-1438.

Walker, K.F. and Thoms, M.C. (1993). Environmental effects of flow regulation on the lower River Murray, Australia. Regulated Rivers: Research and Management 8: 103-119.

Williams, W.D. (2001). Anthropogenic salinisation of inland waters. Hydrobiologia 466: 329-337.

Wilson, P.G. (1980). A revision of the Australian species of Salicornieae (Chenopodiaceae). Nuytsia 3: 3-154.

Young, W.J. (ed.) (2001). Rivers as Ecological Systems: the MurrayDarling Basin. Murray-Darling Basin Commission, Canberra.

Zimmer, W.J. (1937). The Flora of the Far North-west of Victoria: its Distribution in Relation to Soil Types, and its Value in the Prevention of Soil Erosion. Bulletin 2. Forests Commission, Victoria.

Manuscript accepted 28 July 2014 


\section{Appendix 1. Plant community descriptions}

Exotic species are indicated by asterisks. Height and foliage cover are mean values. Mean number of species per plot includes unidentified species, whereas mean numbers of native and exotic species per plot refer only to identified species.

\section{River Red Gum Zone}

1. Eucalyptus camaldulensis - Eleocharis acuta - Pseudoraphis spinescens open-forest

2. Eucalyptus camaldulensis - Eleocharis acuta - Wahlenbergia fluminalis open-forest

3. Eucalyptus camaldulensis - Poa labillardiere - Lachnagrostis filiformis open-forest

4. Eucalyptus camaldulensis - Poa labillardierei - Hemarthria uncinata open-forest

5. Eucalyptus camaldulensis - Carex tereticaulis open-forest

6. Eucalyptus camaldulensis - Paspalidium jubiflorum - Senecio quadridentatus open-forest

7. Eucalyptus camaldulensis - Paspalidium jubiflorum - *Cynodon dactylon woodland

8. Eucalyptus camaldulensis - Cyperus gymnocaulos woodland

9. Eucalyptus camaldulensis - Phragmites australis woodland

10. Eucalyptus camaldulensis - Austrodanthonia caespitosa woodland

11. Eucalyptus camaldulensis - Eucalyptus largiflorens open-forest

12. Eucalyptus camaldulensis - Muehlenbeckia florulenta woodland

13. Eucalyptus camaldulensis - *Bromus diandrus - *Vulpia bromoides open-forest

14. Eucalyptus camaldulensis - *Bromus diandrus - Austrodanthonia caespitosa open-forest

15. Eucalyptus camaldulensis $-*$ Cynodon dactylon woodland

16. *Salix x rubens scrub

17. *Salix babylonica scrub

18. Callistemon brachyandrus - Muehlenbeckia florulenta shrubland

19. Lachnagrostis filiformis - *Cynodon dactylon grassland

20. Pseudoraphis spinescens - Eleocharis acuta herbland

21. Centipeda cunninghamii - Polygonum plebeium herbland

\section{Black Box Zone}

22. Eucalyptus largiflorens - Eleocharis acuta open-forest

23. Eucalyptus largiflorens - Muehlenbeckis florulenta - Chenopodium nitrariaceum woodland

24. Eucalyptus largiflorens - Muehlenbeckia florulenta-Atriplex semibaccata woodland

25. Eucalyptus largiflorens - Melaleuca lanceolata - Allocasuarina luehmannii woodland

26. Eucalyptus largiflorens - Melaleuca lanceolata-Atriplex rhagodiodes woodland

27. Eucalyptus largiflorens - Atriplex nummularia open-woodland

28. Eucalyptus largiflorens - Atriplex rhagodioides woodland

29. Chenopodium nitrariaceum - Muehlenbeckia florulenta shrubland

30. Muehlenbeckia florulenta - Tecticornia pergranulata shrubland

31. Atriplex vesicaria - Tecticornia triandra shrubland

32. Tecticornia pergranulata - Tecticornia indica shrubland

33. Sporobolus mitchellii-Atriplex leptocarpa grassland

\section{Rises within the Floodplain}

34. Eucalyptus microcarpa open-forest

35. Eucalyptus melliodora woodland

36. Callitris glaucophylla woodland

37. Dodonaea viscosa - Callitris gracilis shrubland 


\section{RIVER RED GUM ZONE}

\section{Eucalyptus camaldulensis - Eleocharis acuta - Pseudoraphis spinescens open-forest (Fig. 15)}

$\begin{array}{llll}\text { Layer } & \text { Height }(\mathbf{m}) & \text { Foliage cover }(\%) & \text { Main species } \\ \text { Tree } & 24 & 30 & \text { Eucalyptus camaldulensis } \\ \text { Tall herb } & 0.8 & 15 / 0 & \text { Cyperus exaltatus } \text { or absent } \\ \text { Low herb } & 0.3 & 55 & \text { Eleocharis acuta, Centipeda cunninghamii, Pseudoraphis spinescens, } \\ & & & \begin{array}{l}\text { Alternanthera denticulata, Paspalidium jubiflorum, Rumex brownii, } \\ \text { Lachnagrostis filiformis, Myriophyllum crispatum }\end{array}\end{array}$

Number of plots: 26

Mean number of species per plot (including unidentified): 14.4 (range 7-31)

Mean number of native species per plot: 12 (range 6-22)

Mean number of exotic species per plot: 2.3 (range 0-9)

Mean percentage of chenopod species per plot: 0

River Red Gum condition: $81 \%$ healthy, $15 \%$ unhealthy, $4 \%$ dead $(n=361)$

River Red Gum regeneration: 838 per ha $(6 \%<1 \mathrm{~m}, 17 \% 1-4 \mathrm{~m}, 77 \%>4 \mathrm{~m})$

Mean grazing index (number of dropping clusters per $20 \mathrm{~m}$ ): 1.65 (sheep 0.54, cattle 0.67, rabbit 0.21, pig 0.02, kangaroo 0.21)

Distribution: NSW (13 plots), Victoria (12 plots) and South Australia (1 plot), in Sections 1 (1 plot), 3 (9 plots), 4 (11 plots), 5 (3 plots) and 6 (2 plots). Found in sites subject to frequent flooding. Covers extensive low-lying areas away from the river in Sections 3 and 4 ; elsewhere found close to the river or to other water bodies.

Notes: This community includes the tallest Murray floodplain forests. In River Section 3 the average height of the trees at maturity exceeds $30 \mathrm{~m}$, with some stands exceeding $45 \mathrm{~m}$ (NSW Forestry Commission 1985, Chesterfield 1986). The relatively low average height for the sample plots reflects their history of intensive logging, which has seen old growth trees replaced by younger, lower trees.

\section{Eucalyptus camaldulensis - Eleocharis acuta - Wahlenbergia fluminalis open-forest}

$\begin{array}{llll}\text { Layer } & \text { Height }(\mathbf{m}) & \text { Foliage cover }(\boldsymbol{\%}) & \text { Main species } \\ \text { Tree } & 21 & 40 & \text { Eucalyptus camaldulensis } \\ \text { Herb } & 0.3 & 70 & \begin{array}{l}\text { Eleocharis acuta, Lachnagrostis filiformis, Ranunculus inundatus, Juncus amabilis, } \\ \text { Wahlenbergia fluminalis, Centipeda cunninghamii, Rumex brownii, Myriophyllum } \\ \text { Number of plots: } 4\end{array}\end{array}$

Mean number of species per plot (including unidentified): 33 (range 26-47)

Mean number of native species per plot: 22.5 (range 20-28)

Mean number of exotic species per plot: 10 (range 6-18)

Mean percentage of chenopod species per plot: 0

River Red Gum condition: $76 \%$ healthy, $19 \%$ unhealthy, $5 \%$ dead $(n=42)$

River Red Gum regeneration: 169 per ha $(11 \%<1 \mathrm{~m}, 22 \% 1-4 \mathrm{~m}, 67 \%>4 \mathrm{~m})$

Mean grazing index (number of dropping clusters per 20 m): 4.88 (sheep 1.5, cattle 1.38, rabbit 1, kangaroo 1)

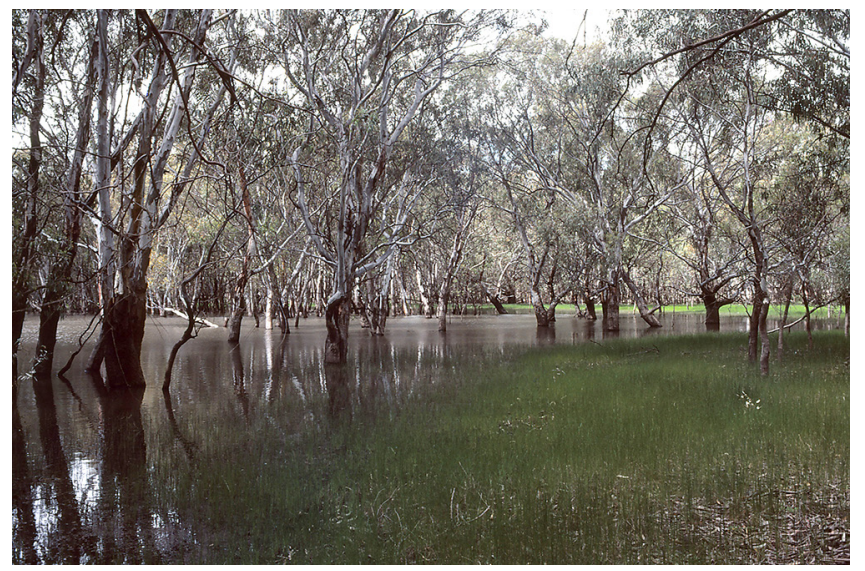

Fig. 15. Community 1, Eucalyptus camaldulensis-Eleocharis acuta-Pseudoraphis spinescens open-forest, near Nyah in Section 4, showing new growth of Eleocharis acuta as floodwaters recede.

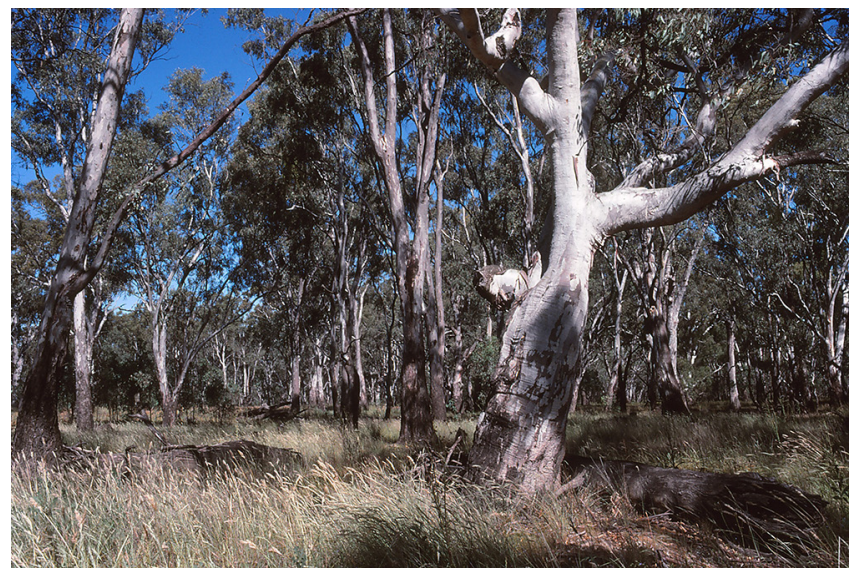

Fig. 16. Community 3, Eucalyptus camaldulensis-Poa labillardierei-Lachnagrostis filiformis open-forest, near Corowa in Section 1, with an understorey dominated by Austrodanthonia duttoniana. 
Distribution: NSW ( 2 plots) and Victoria ( 2 plots), in Sections 3 (1 plot) and 4 (3 plots). Similar to the more widespread Community 1. The two communities were found together at 3 of the 4 sites. In each case, Community 2 occurred on higher ground than Community 1.

\section{Eucalyptus camaldulensis - Poa labillardierei - Lachnagrostis filiformis open-forest (Fig. 16)}

$\begin{array}{llll}\text { Layer } & \text { Height }(\mathbf{m}) & \text { Foliage cover }(\boldsymbol{\%}) & \text { Main species } \\ \text { Tree } & 23 & 45 & \text { Eucalyptus camaldulensis } \\ \text { Shrub } & 5 & 15 / 0 & \text { Acacia dealbata, but mostly absent } \\ \text { Tall herb } & 1 & 30 & \text { Poa labillardierei, Carex tereticaulis, Juncus amabilis } \\ \text { Low herb } & 0.3 & 45 & \text { Lachnagrostis filiformis, *Cynodon dactylon, *Lolium perenne } x \text { rigidum, *Cirsium } \\ & & & \text { vulgare, Centipeda cunninghamii, *Hypochaeris radicata, Eleocharis acuta, } \\ & & & \text { Wahlenbergia fluminalis }\end{array}$

Number of plots: 30

Mean number of species per plot (including unidentified): 37.1 (range 21-57)

Mean number of native species per plot: 20.0 (range 7-30)

Mean number of exotic species per plot: 16.7 (range 4-30)

Mean percentage of chenopod species per plot: 0

River Red Gum condition: $76 \%$ healthy, $19 \%$ unhealthy, 5\% dead $(n=330)$

River Red Gum regeneration: 762 per ha $(30 \%<1 \mathrm{~m}, 40 \% 1-4 \mathrm{~m}, 30 \%>4 \mathrm{~m})$

Mean grazing index (number of dropping clusters per 20 m): 2.45 (sheep 0.17, cattle 1.07, rabbit 0.48, kangaroo 0.73)

Distribution: NSW (12 plots) and Victoria (18 plots), in Sections 1 (11 plots), 2 (5 plots), 3 (10 plots) and 4 (4 plots). Generally found close to the river or to other water bodies, or in floodplain depressions. Community 3 and the weedy Community 13 are the main floodplain communities in Sections 1 and 2, with Community 3 typically found in more frequently flooded sites than Community 13.

\section{Eucalyptus camaldulensis - Poa labillardierei - Hemarthria uncinata open-forest}

$\begin{array}{llll}\text { Layer } & \text { Height }(\mathbf{m}) & \text { Foliage cover }(\%) & \text { Main species } \\ \text { Tree } & 24 & 30 & \text { Eucalyptus camaldulensis } \\ \text { Shrub } & 7 & 5 / 0 & \text { Acacia dealbata } \text { or absent } \\ \text { Tall herb } & 0.9 & 20 & \text { Poa labillardierei, Carex tereticaulis, Juncus amabilis } \\ \text { Low herb } & 0.2 & 60 & \text { Hemarthria uncinata, Persicaria prostrata, *Lolium perenne } x \text { rigidum, } \\ & & & \text { *Hypochaeris radicata, *Cirsium vulgare, *Vulpia bromoides, *Cynodon dactylon, } \\ & & & \text { *Paspalum dilatatum }\end{array}$

Number of plots: 7

Mean number of species per plot (including unidentified): 33.3 (range 22-43)

Mean number of native species per plot: 14.6 (range 7-22)

Mean number of exotic species per plot: 18.6 (range 13-26)

Mean percentage of chenopod species per plot: 0

River Red Gum condition: $84 \%$ healthy, $15 \%$ unhealthy, $1 \%$ dead $(n=89)$

River Red Gum regeneration: 50 per ha $(14 \%<1 \mathrm{~m}, 7 \% 1-4 \mathrm{~m}, 79 \%>4 \mathrm{~m})$

Mean grazing index (number of dropping clusters per 20 m): 10.86 (sheep 0.43, cattle 0.86, rabbit 9.29, kangaroo 0.29)

Distribution: NSW (4 plots) and Victoria ( 3 plots), in Sections 1 ( 2 plots) and 2 (5 plots). Similar to the more widespread Community 3 and, like that community, typically found close to the river or to other water bodies. Community 4 was often associated with sandy soils, particularly in Boomanoomana State Forest in Section 2, where 3 of the 7 plots were located.

\section{Eucalyptus camaldulensis - Carex tereticaulis open-forest (Fig. 17)}

$\begin{array}{llll}\text { Layer } & \text { Height }(\mathbf{m}) & \text { Foliage cover }(\%) & \text { Main species } \\ \text { Tree } & 23 & 40 & \text { Eucalyptus camaldulensis } \\ \text { Tall herb } & 1 & 45 & \text { Carex tereticaulis, Poa labillardierei } \\ \text { Low herb } & 0.2 & 35 & \begin{array}{l}\text { Wahlenbergia fluminalis, *Hypochaeris glabra, *Lactuca serriola, *Sonchus } \\ \text { oleraceus, *Lolium perenne x rigidum, *Bomus hordeaceus, *Vulpia bromoides, } \\ \end{array}\end{array}$

Number of plots: 11

Mean number of species per plot (including unidentified): 35.3 (range 21-50)

Mean number of native species per plot: 19.5 (range 13-29)

Mean number of exotic species per plot: 15.6 (range 8-26)

Mean percentage of chenopod species per plot: $1 \%$

River Red Gum condition: $81 \%$ healthy, $14 \%$ unhealthy, $5 \%$ dead $(n=136)$

River Red Gum regeneration: 966 per ha $(43 \%<1 \mathrm{~m}, 27 \% 1-4 \mathrm{~m}, 30 \%>4 \mathrm{~m})$ 
Mean grazing index (number of dropping clusters per 20 m): 2.14 (sheep 0.05, cattle 0.59, rabbit 0.23, pig 0.05, kangaroo 1.23)

Distribution: NSW ( 7 plots) and Victoria (4 plots), in Sections 3 ( 7 plots) and 4 (4 plots, all in the eastern half). Community 5 is one of the two main floodplain communities in Section 3, together with Community 6.

Notes: Chesterfield (1986) has suggested that logging and grazing may have led to an expansion of Community 5 at the expense of Community 6 (E. camaldulensis - Paspalidium jubiflorum - Senecio quadridentatus open-forest). His reasoning is that Carex tereticaulis tends to be associated with higher tree densities than Paspalidium jubiflorum, and that Carex tereticaulis is unpalatable to stock, whereas Paspalidium jubiflorum is palatable.

\section{Eucalyptus camaldulensis - Paspalidium jubiflorum - Senecio quadridentatus open-forest (Fig. 18)}

$\begin{array}{llll}\text { Layer } & \text { Height }(\mathbf{m}) & \text { Foliage cover }(\boldsymbol{\%}) & \text { Main species } \\ \text { Tree } & 20 & 35 & \text { Eucalyptus camaldulensis } \\ \text { Herb } & 0.4 & 55 & \begin{array}{l}\text { Paspalidium jubiflorum, Wahlenbergia fluminalis, *Hypochaeris glabra, } \\ \text { Lachnagrostis filiformis, } \text { *Lolium perenne } x \text { rigidum, Senecio quadridentatus, }\end{array} \\ & & & * \text { Sonchus oleraceus, Centipeda cunninghamii }\end{array}$

Number of plots: 25

Lachnagrostis filiformis, *Lolium perenne x rigidum, Senecio quadridentatus,

Mean number of species per plot (including unidentified): 31.3 (range 20-50)

Mean number of native species per plot: 17.3 (range 10-28)

Mean number of exotic species per plot: 13.6 (range 5-23)

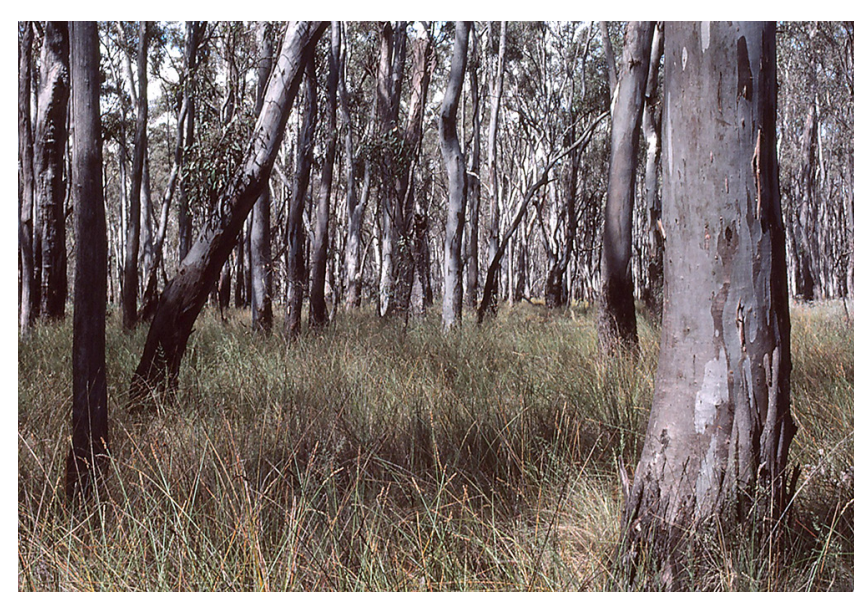

Fig. 17. Community 5, Eucalyptus camaldulensis-Carex tereticaulis open-forest, in Millewa State Forest in Section 3, with an understorey dominated by Carex tereticaulis.

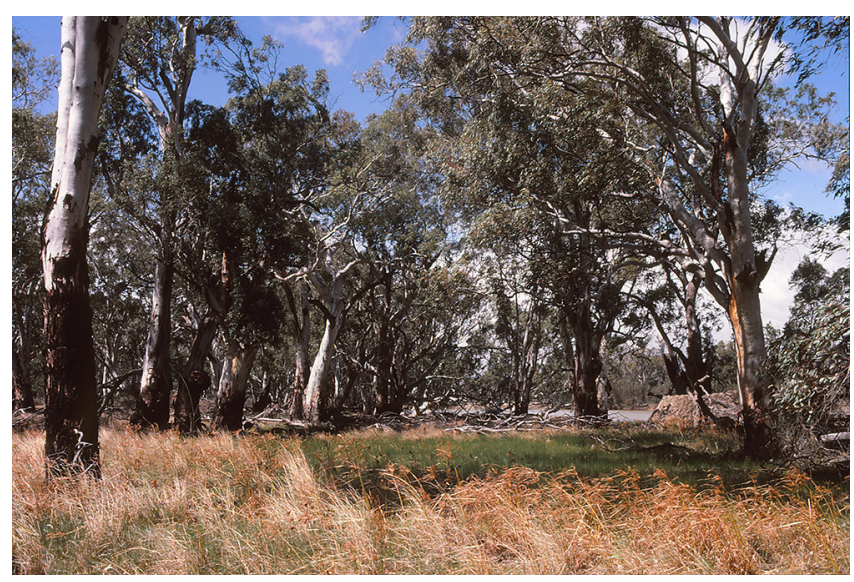

Fig. 19. Community 7, Eucalyptus camaldulensis-Paspalidium jubiflorum-*Cynodon dactylon woodland, in Chowilla Station in Section 6, with Cyperus exaltatus in the understorey, surrounding a patch of Eleocharis acuta.

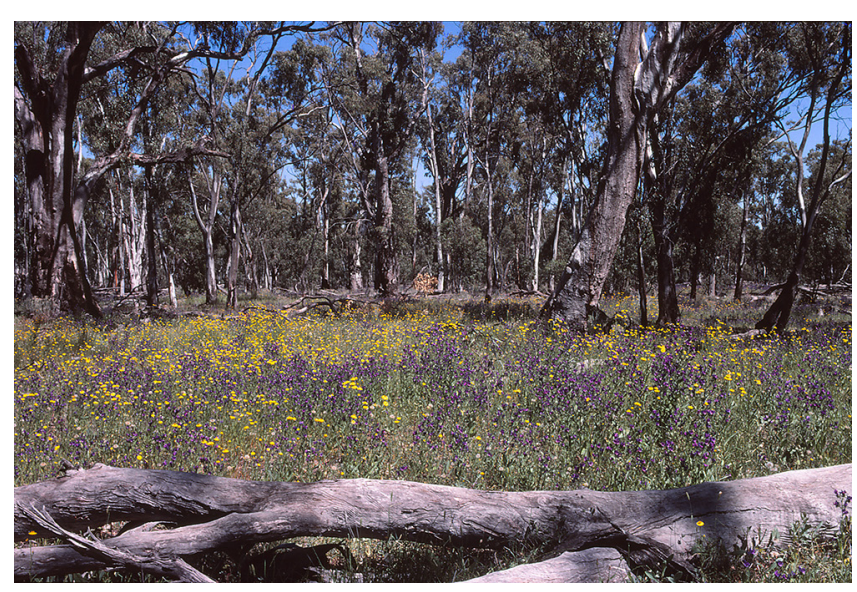

Fig. 18. Community 6, Eucalyptus camaldulensis-Paspalidium jubiflorum-Senecio quadridentatus open-forest, in Werai State Forest (Edward River) in Section 4, with an understorey dominated by Xerochrysum bracteatum and *Echium plantagineum.

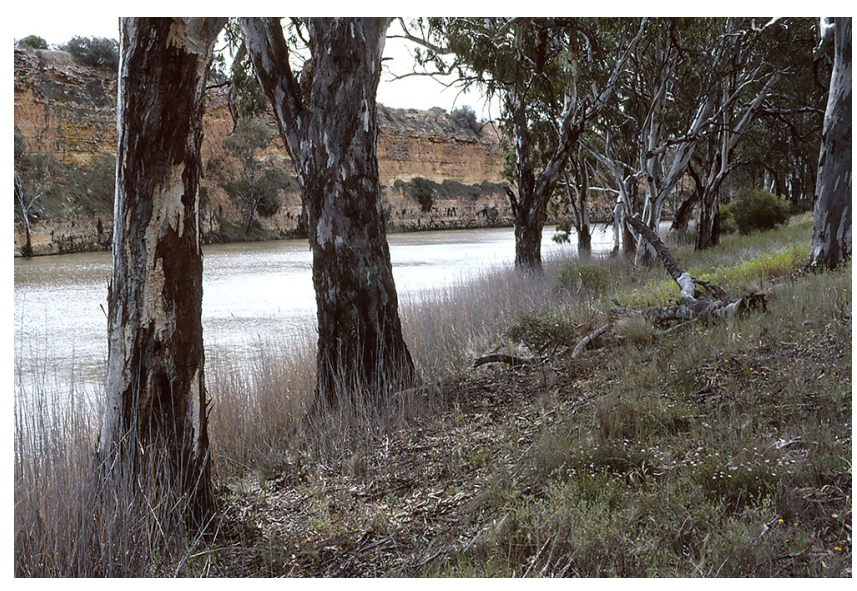

Fig. 20. Community 8, Eucalyptus camaldulensis-Cyperus gymnocaulos woodland, near Waikerie in Section 7, showing a band of Phragmites australis along the water's edge, which is typical of the South Australian section of the river. 
Mean percentage of chenopod species per plot: $1 \%$

River Red Gum condition: $72 \%$ healthy, $19 \%$ unhealthy, $9 \%$ dead $(\mathrm{n}=298)$

River Red Gum regeneration: 861 per ha $(13 \%<1 \mathrm{~m}, 41 \% 1-4 \mathrm{~m}, 46 \%>4 \mathrm{~m})$

Mean grazing index (number of dropping clusters per $20 \mathrm{~m}$ ): 5 (sheep 0.58, cattle 0.58, rabbit 1.68, pig 0.12, kangaroo 2.02, emu 0.02)

Distribution: NSW (22 plots) and Victoria ( 3 plots), in Sections 2 ( 2 plots), 3 (5 plots) and 4 (18 plots). The most extensive River Red Gum community in Section 4 and one of the two most extensive communities in Section 3 (together with Community 5).

\section{Eucalyptus camaldulensis - Paspalidium jubiflorum - *Cynodon dactylon woodland (Fig. 19)}

\begin{tabular}{|c|c|c|c|}
\hline Layer & Height (m) & Foliage cover $(\%)$ & Main species \\
\hline Tree & 21 & 25 & Eucalyptus camaldulensis \\
\hline Tall shrub & 6 & $5 / 0$ & Acacia stenophylla, but mostly absent \\
\hline Low shrub & 1.6 & $5 / 0$ & Muehlenbeckia florulenta, but mostly absent \\
\hline Tall herb & 1 & $15 / 0$ & Phragmites australis or Cyperus exaltatus beside the water, but mostly absen \\
\hline Low herb & 0.4 & 60 & $\begin{array}{l}\text { Paspalidium jubiflorum, *Cynodon dactylon, Wahlenbergia fluminalis, } \\
\text { *Hypochaeris glabra, *Sonchus oleraceus, Centipeda cunninghamii, Eclipta } \\
\text { platyglossa, Cyperus gymnocaulos }\end{array}$ \\
\hline
\end{tabular}

Number of plots: 28

Mean number of species per plot (including unidentified): 29.6 (range 16-48)

Mean number of native species per plot: 18.5 (range 9-30)

Mean number of exotic species per plot: 10.8 (range 5-23)

Mean percentage of chenopod species per plot: $5 \%$

River Red Gum condition: 76\% healthy, $19 \%$ unhealthy, $5 \%$ dead $(\mathrm{n}=290)$

River Red Gum regeneration: 463 per ha $(33 \%<1 \mathrm{~m}, 38 \% 1-4 \mathrm{~m}, 29 \%>4 \mathrm{~m})$

Mean grazing index (number of dropping clusters per 20 m): 6.21 (sheep 3.43, cattle 0.27, rabbit 1.16, kangaroo 1.36)

Distribution: NSW (13 plots), Victoria (5 plots) and South Australia (10 plots), in Sections 4 (5 plots), 5 (7 plots), 6 (11 plots) and 7 (5 plots). The most extensive River Red Gum community in Section 5 and the eastern half of Section 6.

\section{Eucalyptus camaldulensis - Cyperus gymnocaulos woodland (Fig. 20)}

$\begin{array}{llll}\text { Layer } & \text { Height }(\mathbf{m}) & \text { Foliage Cover }(\%) & \text { Main species } \\ \text { Tree } & 20 & 25 & \text { Eucalyptus camaldulensis } \\ \text { Shrub } & 1.8 & 5 & \text { Muehlenbeckia florulenta } \\ \text { Tall herb } & 1.7 & 15 & \text { Phragmites australis beside the water } \\ \text { Low herb } & 0.4 & 55 & \text { Cyperus gymnocaulos, Sporobolus mitchellii, Eclipta platyglossa, Wahlenbergia } \\ & & & \text { fluminalis, *Cynodon dactylon, *Sonchus oleraceus, Paspalidium jubiflorum, } \\ & & & \text { Sonchus hydrophilus }\end{array}$

Number of plots: 12

Mean number of species per plot (including unidentified): 24.3 (range 19-32)

Mean number of native species per plot: 15.5 (range 9-23)

Mean number of exotic species per plot: 8.5 (range 6-13)

Mean percentage of chenopod species per plot: $3 \%$

River Red Gum condition: $70 \%$ healthy, $15 \%$ unhealthy, $15 \%$ dead $(\mathrm{n}=129)$

River Red Gum regeneration: 273 per ha $(0 \%<1 \mathrm{~m}, 30 \% 1-4 \mathrm{~m}, 70 \%>4 \mathrm{~m})$

Mean grazing index (number of dropping clusters per $\mathbf{2 0}$ m): 4.17 (sheep 2.21, cattle 0.21, rabbit 0.17, kangaroo 1.58)

Distribution: All plots in South Australia, in Sections 6 (5 plots) and 7 ( 7 plots). Found close to the river or to other water bodies. The most extensive River Red Gum community in Section 7 and the western half of Section 6.

\section{Eucalyptus camaldulensis - Phragmites australis woodland}

$\begin{array}{llll}\text { Layer } & \text { Height }(\mathbf{m}) & \text { Foliage cover }(\%) & \text { Main species } \\ \text { Tree } & 16 & 20 & \text { Eucalyptus camaldulensis } \\ \text { Shrub } & 2.5 & 5 & \text { Muehlenbeckia florulenta } \\ \text { Tall herb } & 1.7 & 55 & \text { Phragmites australis, Typha species, Schoenoplectus validus } \\ \text { Low herb } & 0.4 & 35 & \text { *Cynodon dactylon, Asperula gemella, Cyperus gymnocaulos, Paspalidium } \\ & & & \text { jubiflorum, Sonchus hydrophilus, *Cirsium vulgare, }{ }^{*} \text { Bromus diandrus, Picris } \\ & & & \text { squarrosa }\end{array}$

Number of plots: 5

Mean number of species per plot (including unidentified): 18.8 (range 10-31) 
Mean number of native species per plot: 11.2 (range 8-19)

Mean number of exotic species per plot: 7.4 (range 2-11)

Mean percentage of chenopod species per plot: $2 \%$

River Red Gum condition: $80 \%$ healthy, $10 \%$ unhealthy, $10 \%$ dead ( $\mathrm{n}=50)$

River Red Gum regeneration: 60 per ha $(0 \%<1 \mathrm{~m}, 67 \% 1-4 \mathrm{~m}, 33 \%>4 \mathrm{~m})$

Mean grazing index (number of dropping clusters per 20 m): 0.8 (cattle 0.4 , rabbit 0.4 )

Distribution: All plots in South Australia, in Sections 7 (4 plots) and 8 ( 1 plot). Found on the edge of the river where there is a wide band of Phragmites australis on low-lying ground at the water's edge. On steeper riverbanks, where there is only a narrow band of Phragmites australis, the vegetation type is Community 8 .

\section{Eucalyptus camaldulensis - Austrodanthonia caespitosa woodland (Fig. 21)}

\begin{tabular}{|c|c|c|c|}
\hline Layer & Height (m) & Foliage cover $(\%)$ & Main species \\
\hline Tree & 18 & 25 & Eucalyptus camaldulensis \\
\hline Tall herb & 0.7 & 5 & Juncus flavidus, Carex tereticaulis, Poa labillardierei \\
\hline Low herb & 0.3 & 65 & $\begin{array}{l}\text { Austrodanthonia caespitosa, Wahlenbergia fluminalis, *Lolium perenne x rigidum, } \\
\text { *Vulpia myuros, Austrodanthonia duttoniana, *Hypochaeris glabra, Lachnagrostis } \\
\text { filiformis, *Bromus hordeaceus }\end{array}$ \\
\hline
\end{tabular}

Number of plots: 8

Mean number of species per plot (including unidentified): 35.4 (range 26-50)

Mean number of native species per plot: 18.4 (range 9-25)

Mean number of exotic species per plot: 16.9 (range 10-26)

Mean percentage of chenopod species per plot: $1 \%$

River Red Gum condition: $72 \%$ healthy, $22 \%$ unhealthy, $6 \%$ dead $(\mathrm{n}=123)$

River Red Gum regeneration: 28 per ha $(45 \%<1 \mathrm{~m}, 33 \% 1-4 \mathrm{~m}, 22 \%>4 \mathrm{~m})$

Mean grazing index (number of dropping clusters per 20 m): 7.06 (sheep 0.06, cattle 3.69, horse 0.19, rabbit 0.94, kangaroo 2.13, emu 0.06)

Distribution: NSW (1 plot) and Victoria (7 plots), in Sections 2 (3 plots), 3 (3 plots) and 4 (2 plots). Typically found in less frequently flooded sites on the outer fringes of the River Red Gum zone.

\section{Eucalyptus camaldulensis - E. largiflorens open-forest}

$\begin{array}{llll}\text { Layer } & \text { Height }(\mathbf{m}) & \text { Foliage cover }(\boldsymbol{\%}) & \text { Main species } \\ \text { Tree } & 18 & 35 & \text { Eucalyptus camaldulensis, E. largiflorens } \\ \text { Shrub } & 1.9 & 15 / 0 & \text { Muehlenbeckia florulenta } \text { or Exocarpos strictus or Acacia } \text { spp. or absent } \\ \text { Tall herb } & 0.8 & 15 / 0 & \text { Cyperus exaltatus beside the water, but mostly absent } \\ \text { Low herb } & 0.1 & 25 & \text { *Hypochaeris glabra, *Sonchus oleraceus, *Vulpia myuros, *Lolium perenne } x \\ & & & \begin{array}{l}\text { rigidum, Wahlenbergia fluminalis, } \\ \text { Oxalis perennans }\end{array}\end{array}$

Number of plots: 13

Mean number of species per plot (including unidentified): 24.7 (range 12-41)

Mean number of native species per plot: 15.3 (range 9-24)

Mean number of exotic species per plot: 8.8 (range 3-16)

Mean percentage of chenopod species per plot: $5 \%$

River Red Gum condition: 55\% healthy, 37\% unhealthy, $8 \%$ dead ( $\mathrm{n}=122)$

Black Box condition: $49 \%$ healthy, $44 \%$ unhealthy, $7 \%$ dead $(n=95)$

River Red Gum regeneration: 67 per ha $(46 \%<1 \mathrm{~m}, 26 \% 1-4 \mathrm{~m}, 28 \%>4 \mathrm{~m})$

Black Box regeneration (8 plots): 469 per ha (10\%<1 m, 35\% 1-4 m, 55\% >4 m)

Mean grazing index (number of dropping clusters per $\mathbf{2 0}$ m): 4.77 (sheep 1.88, cattle 0.58, rabbit 1.19, pig 0.04, kangaroo 1, emu 0.08)

Distribution: NSW (7 plots) and Victoria (6 plots), in Sections 4 (8 plots) and 5 (5 plots). Typically found at the junction of the River Red Gum and Black Box zones, either on the floodplain or on river and creek banks (particularly where the banks are steep and high). However, Eucalyptus largiflorens was absent from 5 of the 13 plots (E. camaldulensis was present in every plot).

Notes: A rather heterogeneous grouping that includes one plot where the vegetation appeared to be changing from a River Red Gum community to a Black Box community, and another plot where the reverse appeared to be occurring. The latter was a waterside plot upstream of Torrumbarry Weir (Section 4), which would have been located away from the water's edge before construction of the weir. The reason for the apparent vegetation change at the other plot was unclear. 


\section{Eucalyptus camaldulensis - Muehlenbeckia florulenta woodland (Fig. 22)}

$\begin{array}{llll}\text { Layer } & \text { Height }(\mathbf{m}) & \text { Foliage cover }(\%) & \text { Main species } \\ \text { Tree } & 18 & 25 & \text { Eucalyptus camaldulensis, some E. largiflorens } \\ \text { Tall shrub } & 7 & 5 & \text { Acacia stenophylla, sometimes forming dense stands } \\ \text { Low shrub } & 1.6 & 10 & \text { Muehlenbeckia florulenta } \\ \text { Low herb } & 0.4 & 60 & \begin{array}{l}\text { Paspalidium jubiflorum, *Bromus rubens, *Hypochaeris glabra, Cyperus } \\ \text { gymnocaulos, Wahlenbergia fluminalis, Einadia nutans, }\end{array} \\ & & & * \text { Cynodonch dactylon }\end{array}$

Number of plots: 13

Mean number of species per plot (including unidentified): 27.2 (range 14-42)

Mean number of native species per plot: 17.1 (range 8-28)

Mean number of exotic species per plot: 9.9 (range 6-14)

Mean percentage of chenopod species per plot: $10 \%$

River Red Gum condition: $50 \%$ healthy, $35 \%$ unhealthy, $15 \%$ dead $(n=124)$

Black Box condition: $95 \%$ healthy, $5 \%$ unhealthy, $0 \%$ dead $(n=40)$

River Red Gum regeneration (11 plots): 43 per ha $(5 \%<1 \mathrm{~m}, 53 \% 1-4 \mathrm{~m}, 42 \%>4 \mathrm{~m})$

Black Box regeneration (4 plots): 13 per ha $(100 \%>4 \mathrm{~m})$

Mean grazing index (number of dropping clusters per $\mathbf{2 0}$ m): 4.77 (sheep 1, cattle 0.35, rabbit 2.77, kangaroo 0.65)

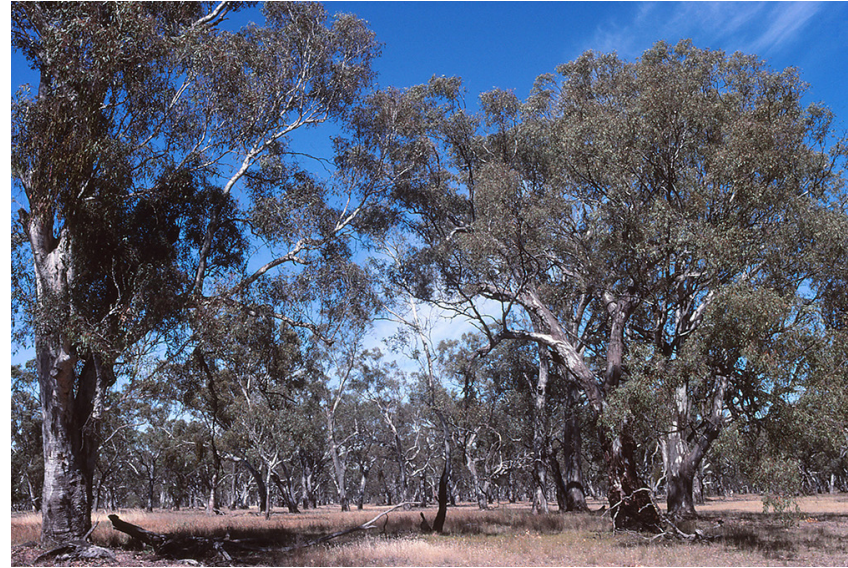

Fig. 21. Community 10, Eucalyptus camaldulensisAustrodanthonia caespitosa woodland, on Ulupna Island in Section 2.

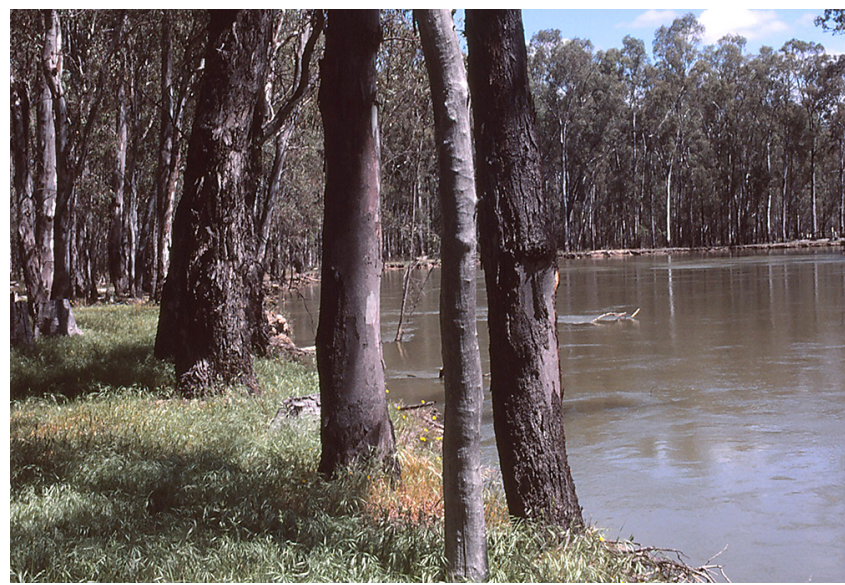

Fig. 23. Community 13, Eucalyptus camaldulensis-*Bromus diandrus-*Vulpia bromoides open-forest, in Barmah State Forest in Section 3, with an understorey dominated by *Bromus diandrus.

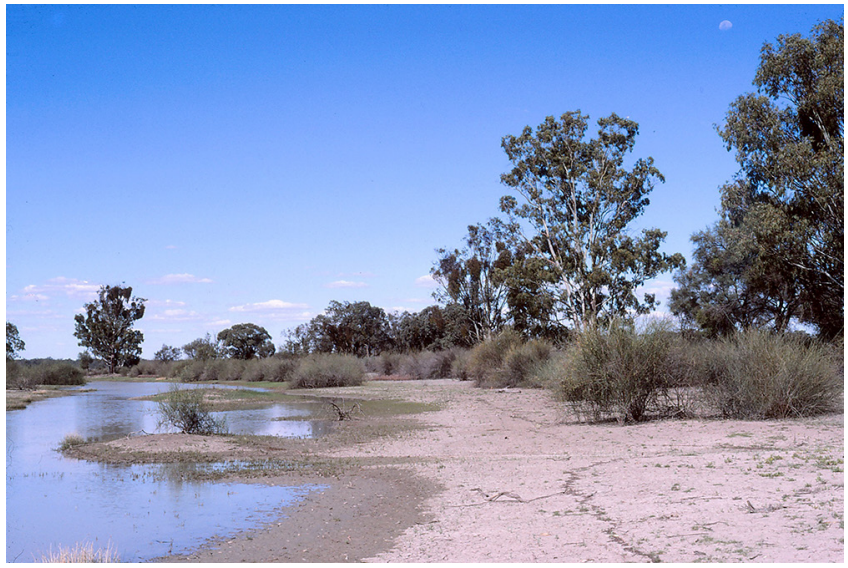

Fig. 22. Community 12, Eucalyptus camaldulensis-Muehlenbeckia florulenta woodland, near Murtho in Section 6, with a dense Muehlenbeckia florulenta understorey.

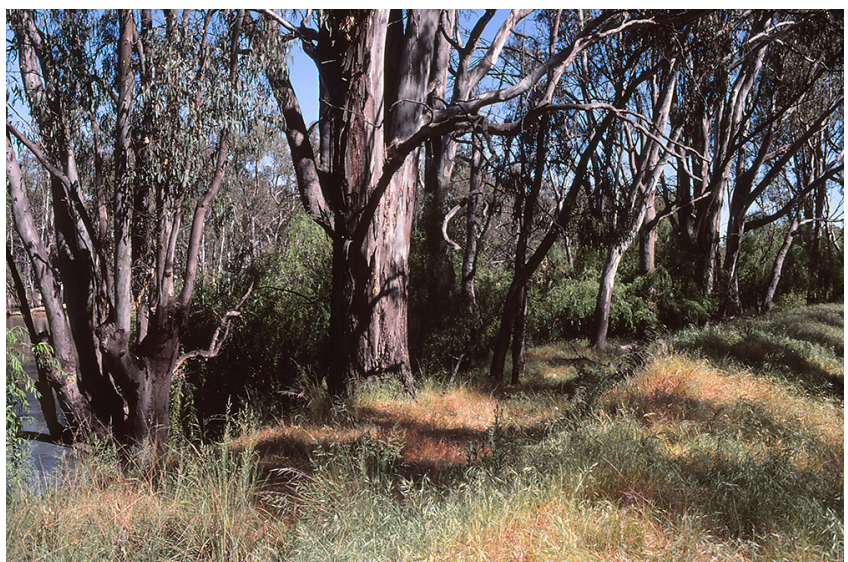

Fig. 24. Community 14, Eucalyptus camaldulensis-*Bromus diandrus-Austrodanthonia caespitosa open-forest, near Stevens Weir (Edward River) in Section 4, with *Salix babylonica growing along the water's edge and *Bromus diandrus and Austrodanthonia duttoniana dominant on top of the bank. 
Distribution: Victoria (4 plots) and South Australia (9 plots), in Sections 5 (4 plots), 6 (3 plots) and 7 (6 plots). Typically found on sandy soils at the junction of the River Red Gum and Black Box zones, either on the floodplain or, more often, on high river and creek banks.

Notes: Eucalyptus largiflorens was present in 4 of the 13 plots and the only eucalypt in two of those plots (i.e. no E. camaldulensis).

\section{Eucalyptus camaldulensis - *Bromus diandrus - *Vulpia bromoides open-forest (Fig. 23)}

Layer Height (m) Foliage cover (\%) Main species

$\begin{array}{llll}\text { Tree } & 22 & 35 & \text { Eucalyptus camaldulensis } \\ \text { Shrub } & 2.5-6 & 15 / 0 & \text { Acacia dealbata }(6 \mathrm{~m}) \text { or *Salix spp. (6 m) or Exocarpos strictus }(2.5 \mathrm{~m}), \text { but mostly absent } \\ \text { Tall herb } & 0.8 & 15 / 0 & \text { Carex tereticaulis, Juncus flavidus, J. amabilis or absent } \\ \text { Low herb } & 0.3 & 70 & * \text { Bromus diandrus, *Bromus hordeaceus, *Lolium perenne x rigidum, *Vulpia bromoides, } \\ & & & * \text { Hypochaeris radicata, *Hordeum murinum, *Cynodon dactylon, *Cirsium vulgare }\end{array}$

Number of plots: 21

Mean number of species per plot (including unidentified): 29.1 (range 13-49)

Mean number of native species per plot: 10.7 (range 3-24)

Mean number of exotic species per plot: 18.1 (range 8-26)

Mean percentage of chenopod species per plot: 0

River Red Gum condition: 79\% healthy, $18 \%$ unhealthy, 3\% dead ( $\mathrm{n}=267)$

River Red Gum regeneration: 356 per ha $(37 \%<1 \mathrm{~m}, 27 \% 1-4 \mathrm{~m}, 36 \%>4 \mathrm{~m})$

Mean grazing index (number of dropping clusters per 20 m): 6.17 (sheep 0.07, cattle 2.69, horse 0.05, rabbit 2.52, pig 0.02, kangaroo 0.81)

Distribution: NSW (13 plots) and Victoria (8 plots), in Sections 1 (10 plots), 2 (5 plots), 3 (5 plots) and 4 (1 plot). Occurs in various situations where the native understorey vegetation has been largely replaced by weeds. Typically occurs in less frequently flooded sites than adjacent, less weedy River Red Gum communities. One of the two main floodplain communities in Sections 1 and 2, together with Community 3.

\section{Eucalyptus camaldulensis - *Bromus diandrus - Austrodanthonia caespitosa open-forest (Fig. 24)}

Layer Height (m) Foliage cover (\%) Main species

$\begin{array}{llll}\begin{array}{l}\text { Tree } \\ \text { Shrub }\end{array} & 21 & 30 & \begin{array}{l}\text { Eucalyptus camaldulensis } \\ \text { Acacia dealbata }(6 \mathrm{~m}) \text { or } * \text { Salix babylonica }(5 \mathrm{~m}) \text { or Chenopodium nitrariaceum }(1.5 \mathrm{~m}) \text { or absent }\end{array} \\ \text { Herb } & 1.5-6 & 30 / 0 & \text { *Bromus diandrus, Austrodanthonia caespitosa, *Bromus hordeaceus, *Lolium perenne x rigidum, } \\ & 0.3 & 55 & * \text { Avena barbata, *Hordeum murinum, *Vulpia myuros, *Cirsium vulgare, *Hordeum marinum }\end{array}$

Number of plots: 6

Mean number of species per plot (including unidentified): 28.8 (range 14-38)

Mean number of native species per plot: 12.2 (range 5-16)

Mean number of exotic species per plot: 16.5 (range 9-22)

Mean percentage of chenopod species per plot: $2 \%$

River Red Gum condition: 57\% healthy, $29 \%$ unhealthy, $14 \%$ dead $(\mathrm{n}=90)$

River Red Gum regeneration: 238 per ha $(4 \%<1 \mathrm{~m}, 21 \% 1-4 \mathrm{~m}, 75 \%>4 \mathrm{~m})$

Mean grazing index (number of dropping clusters per 20 m): 1.58 (sheep 0.08, cattle 0.67, rabbit 0.42, kangaroo 0.42)

Distribution: NSW (5 plots) and Victoria (1 plot), all in Section 4. A mixed group of very weedy plots. Four plots were on high riverbanks; the other two plots were associated with dry floodways.

Notes: The Acacia dealbata and *Salix babylonica layers occurred in riverbank plots, while the Chenopodium nitrariaceum layer was in a floodway plot. The dead trees were mainly in the other floodway plot, which appeared to be salt-affected, the understorey being dominated by the salt-tolerant *Hordeum marinum.

\section{Eucalyptus camaldulensis - *Cynodon dactylon woodland (Fig. 25)}

\begin{tabular}{|c|c|c|c|}
\hline Layer & Height (m) & Folia & Main species \\
\hline Tree & 18 & 20 & Eucalyptus camaldulensis \\
\hline Tall shrub & 8 & $10 / 0$ & *Salix babylonica beside the water, but mostly absent \\
\hline Low shrub & 1.8 & 15 & Muehlenbeckia florulenta, Enchylaena tomentosa \\
\hline Tall herb & 1.5 & $5 / 0$ & Schoenoplectus validus beside the water, but mostly absent \\
\hline Low herb & 0.2 & 65 & $\begin{array}{l}* \text { Cynodon dactylon, *Bromus rubens, Cyperus gymnocaulos, *Medicago } \\
\text { polymorpha, *Hordeum murinum, Sonchus hydrophilus, *Cirsium vulgare, *Rumex } \\
\text { crispus }\end{array}$ \\
\hline
\end{tabular}


Mean number of native species per plot: 13.8 (range 7-26)

Mean number of exotic species per plot: 20 (range 14-27)

Mean percentage of chenopod species per plot: $7 \%$

River Red Gum condition: 60\% healthy, $13 \%$ unhealthy, $27 \%$ dead $(n=120)$

River Red Gum regeneration: 88 per ha $(0<1 \mathrm{~m}, 10 \% 1-4 \mathrm{~m}, 90 \%>4 \mathrm{~m})$

Mean grazing index (number of dropping clusters per $20 \mathrm{~m}$ ): 7.5 (cattle 3.96, rabbit 3.54)

Distribution: All plots in South Australia, in Sections 7 (3 plots) and 8 ( 9 plots). Occurs in degraded sites where the native understorey vegetation has been largely replaced by weeds. The most extensive River Red Gum community in Section 8 . The Lower Murray equivalent of the weedy E. camaldulensis - *Bromus diandrus communities of the Upper Murray (Communities 13 and 14).

Notes: The high number of dead trees is a result of raised water levels and, in one plot, salinisation.

\section{6. *Salix $x$ rubens scrub}

\begin{tabular}{|c|c|c|c|}
\hline Layer & Height (m) & Folia & Main species \\
\hline Tree & 16 & $15 / 0$ & Eucalyptus camaldulensis or absent \\
\hline Shrub & 7 & 65 & *Salix $x$ rubens \\
\hline Tall herb & 1 & 15 & Poa labillardierei, Phragmites australis \\
\hline Low herb & 0.3 & 15 & $\begin{array}{l}\text { *Hypochaeris radicata, *Vulpia bromoides, *Conyza bonariensis, Lachnagrostis } \\
\text { filiformis, *Bromus catharticus, *Juncus flavidus, *Cirsium vulgare, *Trifolium } \\
\text { campestre }\end{array}$ \\
\hline
\end{tabular}

Number of plots: 2

Mean number of species per plot (including unidentified): 31.5 (range 17-46)

Mean number of native species per plot: 12.5 (range 5-20)

Mean number of exotic species per plot: 18 (range 12-24)

Mean percentage of chenopod species per plot: 0

River Red Gum condition: $64 \%$ healthy, $36 \%$ unhealthy, 0 dead $(n=11)$

River Red Gum regeneration: 525 per ha $(0<1 \mathrm{~m}, 52 \% 1-4 \mathrm{~m}, 48 \%>4 \mathrm{~m})$

Mean grazing index (number of dropping clusters per 20 m): 1.25 (cattle 1, kangaroo 0.25)

Distribution: Both plots in NSW, in Sections 1 (1 plot) and 3 (1 plot). Occurs in scattered sites where there are stands of *Salix $x$ rubens fringing the river. *Salix $x$ rubens grows further down the riverbank than Eucalyptus camaldulensis and parts of both plots were in water at the time of the survey.

Notes: Although there was dense eucalypt regeneration in one plot, much of it appeared unhealthy, being shaded by the *Salix.

\section{7. *Salix babylonica scrub (Fig. 26)}

$\begin{array}{llll}\text { Layer } & \text { Height }(\mathbf{m}) & \text { Foliage cover }(\%) & \text { Main species } \\ \text { Shrub } & 9 & 60 & * \text { Salix babylonica } \\ \text { Herb } & 0.6 & 25 & \begin{array}{l}\text { Juncus aridicola, *Aster subulatus, Hydrocotyle verticillata, }, \text { Helminthotheca } \\ \text { echioides, Triglochin procera, }{ }^{*} \text { Cirsium vulgare, Lachnagrostis filiformis, Azolla }\end{array} \\ & & & \text { filiculoides, Phragmites australis }\end{array}$

Number of plots: 6 filiculoides, Phragmites australis

Mean number of species per plot (including unidentified): 25.2 (range 17-33)

Mean number of native species per plot: 12.5 (range 8-23)

Mean number of exotic species per plot: 12 (range 9-20)

Mean percentage of chenopod species per plot: 0

Mean grazing index (number of dropping clusters per 20 m): 0.25 (cattle 0.17 , kangaroo 0.08 )

Distribution: All plots in South Australia, in Sections 6 (1 plot) and 8 (5 plots). However, stands of *Salix babylonica occur sporadically in other river sections as well. The community is most extensive in Section 8, where *Salix babylonica typically occurs in a $20-40$ m wide strip between a constructed levee and the river. It is the main riverside vegetation along this part of the river and is virtually continuous below Murray Bridge. *Salix babylonica grows further down the riverbank than Eucalyptus camaldulensis and large parts of all plots (40-80\%) were in water at the time of the survey.

\section{Callistemon brachyandrus - Muehlenbeckia florulenta shrubland (Fig. 27)}

$\begin{array}{llll}\text { Layer } & \text { Height }(\mathbf{m}) & \text { Foliage cover }(\%) \text { Main species } \\ \text { Tall shrub } & 4 & 20 & \text { Callistemon brachyandrus, Muehlenbeckia florulenta } \\ \text { Low shrub } & 0.6 & 5 & \text { Enchylaena tomentosa, Maireana brevifolia } \\ \text { Herb } & 0.2 & 55 & \text { *Bromus rubens, Cyperus gymnocaulos, *Hypochaeris glabra, } * \text { Avena barbata, } \\ & & & \text { *Bassica tournefortii, Calotis cuneifolia, *Euphorbia terracina, Einadia nutans }\end{array}$

Number of plots: 2 
Mean number of species per plot (including unidentified): 30.5 (range 30-31)

Mean number of native species per plot: 17 (range 15-19)

Mean number of exotic species per plot: 13.5 (range 12-15)

Mean percentage of chenopod species per plot: $20 \%$

Mean grazing index (number of dropping clusters per 20 m): 1 (rabbit 1)

Distribution: Only encountered at Morgan Conservation Park in Section 7 in South Australia, growing in very sandy soil on the riverbank and on the floodplain behind.

\section{Lachnagrostis filiformis - *Cynodon dactylon grassland}

$\begin{array}{lll}\text { Layer } & \text { Height }(\mathbf{m}) & \text { Foliage cover }(\%) \\ \text { Sapling } & 3 & 5 \\ \text { Herb } & 0.1 & 60\end{array}$

\section{Main species}

Eucalyptus camaldulensis

Lachnagrostis filiformis, *Cynodon dactylon, Crassula sieberiana, *Lolium perenne $x$ rigidum, Persicaria prostrata, *Hypochaeris radicata, Centipeda cunninghamii, Eragrostis elongata

Number of plots: 3

Mean number of species per plot (including unidentified): 25.3 (range 19-32)

Mean number of native species per plot: 11.7 (range 8-14)

Mean number of exotic species per plot: 13.7 (range 11-18)

Mean percentage of chenopod species per plot: 0

River Red Gum regeneration: 558 per ha (7\% <1 m, 66\% 1-4 m, 27\% >4 m)

Mean grazing index (number of dropping clusters per $20 \mathrm{~m}$ ): 3.83 (cattle 1.17, rabbit 0.33, kangaroo 2.33)

Distribution: All plots in Victoria, in Section 2. Occurs on recent sand deposits, usually point bars.

Notes: This community represents the early stages of colonisation of the broad point bar deposits (beaches) of Section 2 .

\section{Pseudoraphis spinescens - Eleocharis acuta herbland (Fig. 28)}

$\begin{array}{llll}\text { Layer } & \text { Height }(\mathbf{m}) & \text { Foliage cover }(\%) & \text { Main species } \\ \text { Herb } & 0.2 & 85 & \begin{array}{l}\text { Pseudoraphis spinescens, Eleocharis acuta, Centipeda cunninghamii, } \\ \text { Lachnagrostis filiformis, Persicaria hydropiper, } P \text {. prostrata, Alternanthera } \\ \text { denticulata, } * \text { Ludwigia peploides }\end{array}\end{array}$

Number of plots: 4 denticulata, *Ludwigia peploides

Mean number of species per plot (including unidentified): 9.5 (range 3-18)

Mean number of native species per plot: 8 (range 3-15)

Mean number of exotic species per plot: 1.5 (range $0-3$ )

Mean percentage of chenopod species per plot: 0

Mean grazing index (number of dropping clusters per 20 m): 1.5 (cattle 1.38, horse 0.13)

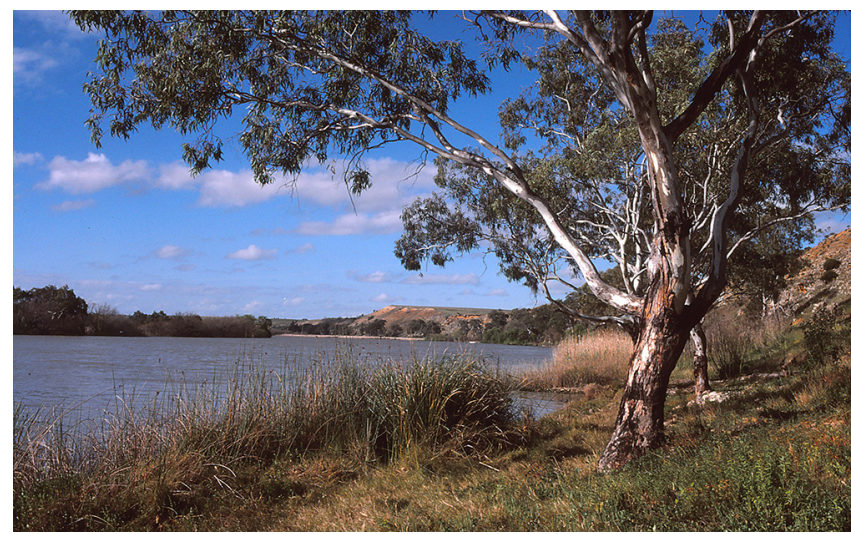

Fig. 25. Community 15, Eucalyptus camaldulensis-*Cynodon dactylon woodland, near Mypolonga in Section 8, with Schoenus validus growing along the water's edge and *Cynodon dactylon and *Medicago polymorpha dominant away from the water.

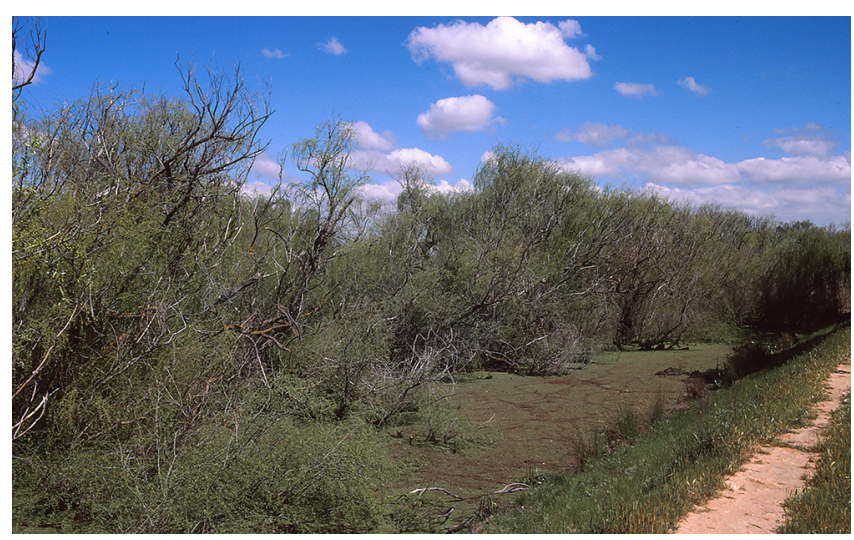

Fig. 26. Community 17, *Salix babylonica scrub, near Ponde in Section 8 . 


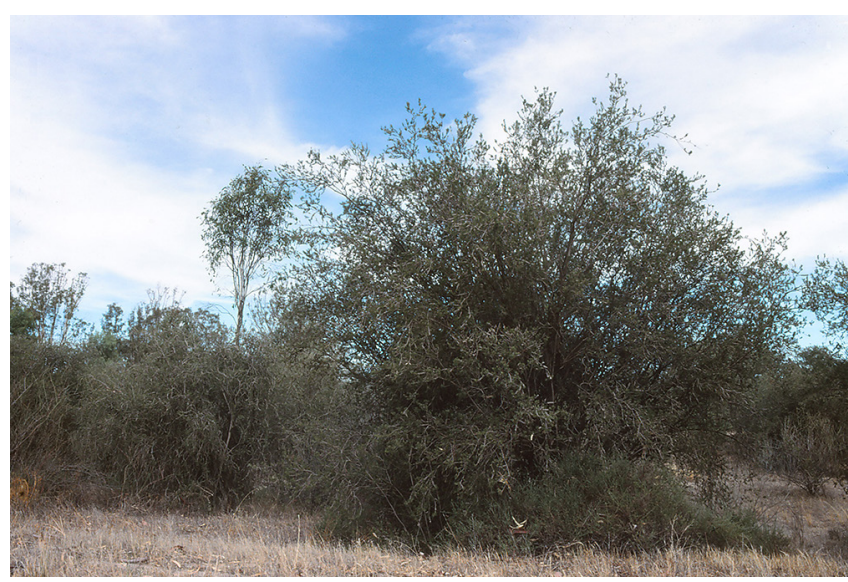

Fig. 27. Community 18, Callistemon brachyandrusMuehlenbeckia florulenta shrubland, in Morgan Conservation Park in Section 7.

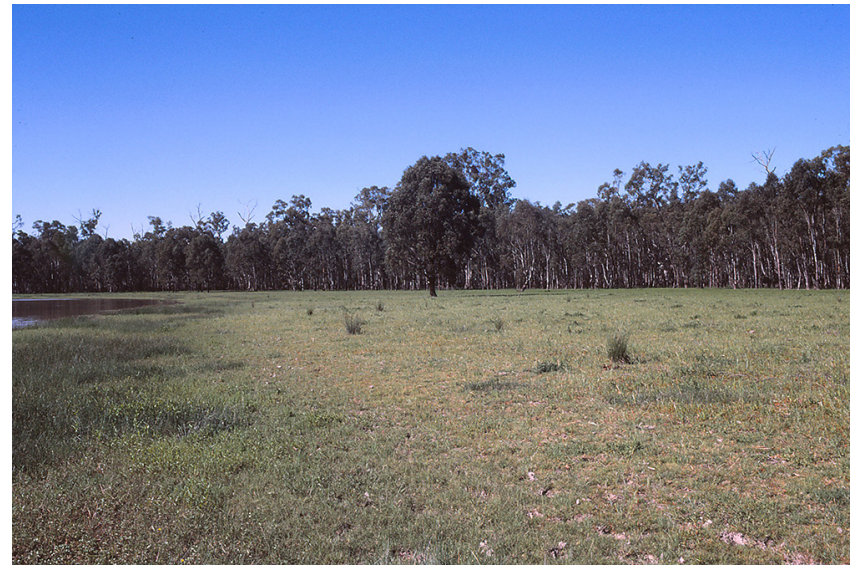

Fig. 28. Community 20, Pseudoraphis spinescens-Eleocharis acuta herbland, in Barmah State Forest in Section 3, with Pseudoraphis spinescens dominant.

Distribution: NSW (1 plot) and Victoria (3 plots), in Sections 3 (plots) and 4 (observed). Occurs on flat, low-lying areas where flooding is too frequent and prolonged for Eucalyptus camaldulensis to grow.

Notes: Varies from Pseudoraphis spinescens grassland to Eleocharis acuta sedgeland.

\section{Centipeda cunninghamii - Polygonum plebeium herbland (Fig. 29)}

$\begin{array}{llll}\text { Layer } & \text { Height }(\mathbf{m}) & \text { Foliage cover }(\%) \text { Main species } \\ \text { Sapling } & 10 & 5 & \text { Eucalyptus camaldulensis } \\ \text { Herb } & 0.2 & 65 & \begin{array}{l}\text { Centipeda cunninghamii, Polygonum plebeium, Persicaria prostrata, } \\ \text { Pseudognaphalium luteoalbum, Centipeda minima, Lachnagrostis filiformis, }\end{array}\end{array}$

Number of plots: 5 Alternanthera denticulata, Rumex crystallinus

Mean number of species per plot (including unidentified): 25 (range 14-35)

Mean number of native species per plot: 16 (range 11-21)

Mean number of exotic species per plot: 9 (range 7-16)

Mean percentage of chenopod species per plot: 0

River Red Gum regeneration: 4065 per ha $(93 \%<1 \mathrm{~m}, 7 \% 1-4 \mathrm{~m}, 0.2 \%>4 \mathrm{~m})$

Mean grazing index (number of dropping clusters per 20 m): 9.7 (sheep 3.5, cattle 0.5, rabbit 5.2, kangaroo 0.5)

Distribution: NSW (4 plots) and Victoria (1 plot), in Sections 2 (1 plot), 4 (2 plots) and 5 (2 plots). Occurs in depressions and on gently sloping edges of billabongs, i.e. in sites that are subject to frequent flooding.

Notes: In addition to the eucalypt seedlings included in the counts, there were thousands of seedlings under $5 \mathrm{~cm}$ high. Germination is prolific after flooding, but most of the seedlings are killed by later flooding. Saplings become established only on the outer edges of the community and on rises within it.

\section{BLACK BOX ZONE}

\section{Eucalyptus largiflorens - Eleocharis acuta open-forest (Fig. 30)}

$\begin{array}{llll}\text { Layer } & \text { Height }(\mathbf{m}) & \text { Foliage cover }(\%) \text { Main species } \\ \text { Tree } & 13 & 35 & \text { Eucalyptus largiflorens } \\ \text { Herb } & 0.4 & 65 & \text { Eleocharis acuta, Lachnagrostis filiformis, Eleocharis pusilla, Juncus flavidus, } \\ & & & \text { *Lolium rigidum, Centipeda cunninghamii, } \\ & & & \text { minus }\end{array}$

Number of plots: 3

Mean number of species per plot (including unidentified): 28.7 (range 23-38)

Mean number of native species per plot: 18 (range 16-22)

Mean number of exotic species per plot: 10.7 (range 7-16)

Mean percentage of chenopod species per plot: 0 


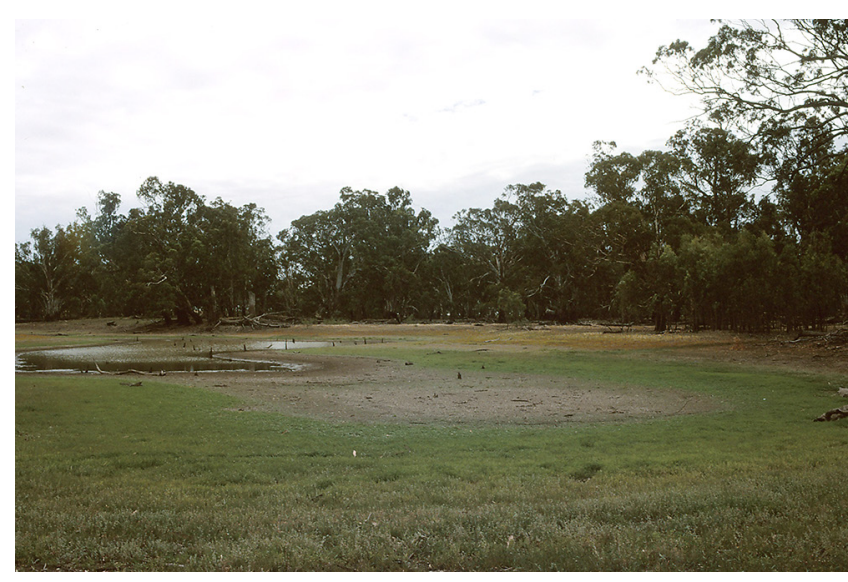

Fig. 29. Community 21, Centipeda cunninghamii-Polygonum plebeium herbland, near Kyalite (Edward River) in Section 4, with a mixture of species including Centipeda cunninghamii, C. minima, Polygonum plebeium, Alternanthera denticulata, Psedognaphalium luteoalbum and Glinus lotoides.

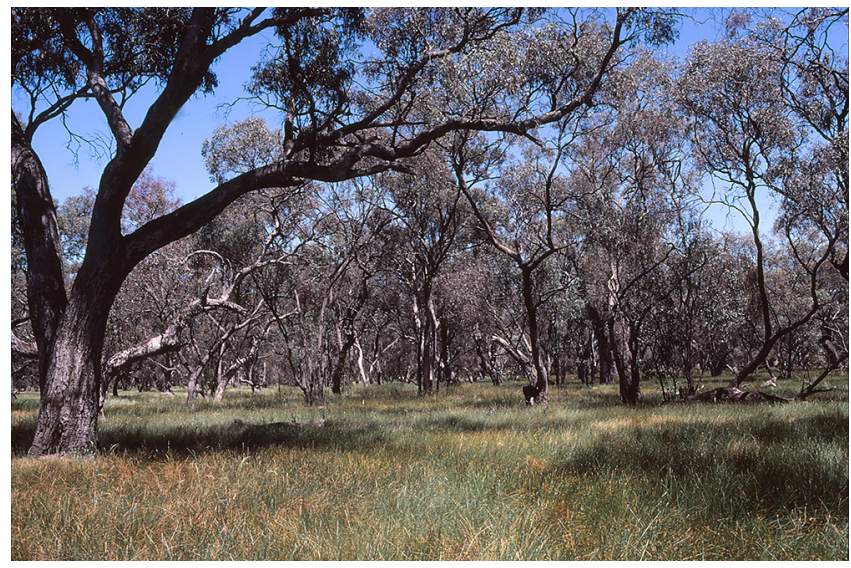

Fig. 30. Community 22, Eucalyptus largiflorens-Eleocharis acuta open-forest, near Torrumbarry in Section 4, showing the dense Eleocharis acuta understorey.

Black Box condition: $74 \%$ healthy, $26 \%$ unhealthy, 0 dead $(n=31)$

Black Box regeneration: None in the plots

Mean grazing index (number of dropping clusters per 20 m): 2 (sheep 0.17, cattle 0.5, rabbit 0.67, kangaroo 0.67)

Distribution: NSW (1 plot) and Victoria (2 plots), in Section 4. Occurs in floodplain sites that are often flooded.

Notes: In some sites, at least, this community appeared to be the result of a recent increase in flooding frequency, which had brought about a change in the understorey vegetation but not yet the tree layer. In time, Eucalyptus largiflorens may be replaced by E. camaldulensis at these sites.

\section{Eucalyptus largiflorens - Muehlenbeckia florulenta - Chenopodium nitrariaceum woodland (Fig. 31)}

$\begin{array}{llll}\text { Layer } & \text { Height }(\mathbf{m}) & \text { Foliage cover }(\%) \text { Main species } \\ \text { Tree } & 12 & 30 & \text { Eucalyptus largiflorens, occasional E. camaldulensis } \\ \text { Tall shrub } & 6 & 15 / 0 & \text { Acacia stenophylla, sometimes forming dense stands but mostly absent } \\ \text { Mid shrub } & 1.3 & 25 / 0 & \text { Muehlenbeckia florulenta, Chenopodium nitrariaceum, sometimes absent } \\ \text { Low shrub } & 0.4 & 10 / 0 & \begin{array}{l}\text { Enchylaena tomentosa, Sclerolaena muricata, S. tricuspis, or absent } \\ \text { Herb }\end{array} \\ & 0.1 & 25 & \begin{array}{l}\text { *Hypochaeris glabra, *Hordeum murinum, Einadia nutans, *Vulpia myuros, } \\ \text { Austrodanthonia caespitosa, Cotula australis, *Sonchus oleraceus, Solanum } \\ \text { esuriale }\end{array}\end{array}$

Number of plots: 19

Mean number of species per plot (including unidentified): 26.2 (range 6-43)

Mean number of native species per plot: 17.3 (range 3-28)

Mean number of exotic species per plot: 8.3 (range 0-17)

Mean percentage of chenopod species per plot: $17 \%$

Black Box condition: $57 \%$ healthy, $32 \%$ unhealthy, $11 \%$ dead $(\mathrm{n}=228)$

Black Box regeneration: 216 per ha $(1 \%<1 \mathrm{~m}, 41 \% 1-4 \mathrm{~m}, 58 \%>4 \mathrm{~m})$

Mean grazing index (number of dropping clusters per 20 m): 8.53 (sheep 0.16, cattle 0.74, rabbit 4.89, kangaroo 2.68, emu 0.05)

Distribution: NSW (7 plots) and Victoria (12 plots), in Sections 4 (7 plots), 5 (10 plots) and 6 (2 plots east of the South Australian border). A common floodplain community in the inner parts of the Black Box zone.

\section{Eucalyptus largiflorens - Muehlenbeckia florulenta - Atriplex semibaccata woodland (Fig. 32)}

\begin{tabular}{|c|c|c|c|}
\hline Layer & Height (m) & Foliage cover $(\%)$ & Main species \\
\hline Tree & 12 & 20 & Eucalyptus largiflorens, occasional E. camaldulensis \\
\hline Tall shrub & 8 & $5 / 0$ & Acacia stenophylla, but mostly absent \\
\hline Mid shrub & 1.5 & 15 & Muehlenbeckia florulenta \\
\hline Low shrub & 0.4 & 10 & Enchylaena toentosa \\
\hline Herb & 0.2 & 35 & $\begin{array}{l}\text { Einadia nutans, Paspalidium jubiflorum, Atriplex semibaccata, *Sonchus oleraceus, } \\
\text { *Hordeum murinum, Senecio spanomerus, Sporobolus mitchellii, *Hypochaeris } \\
\text { glabra }\end{array}$ \\
\hline
\end{tabular}




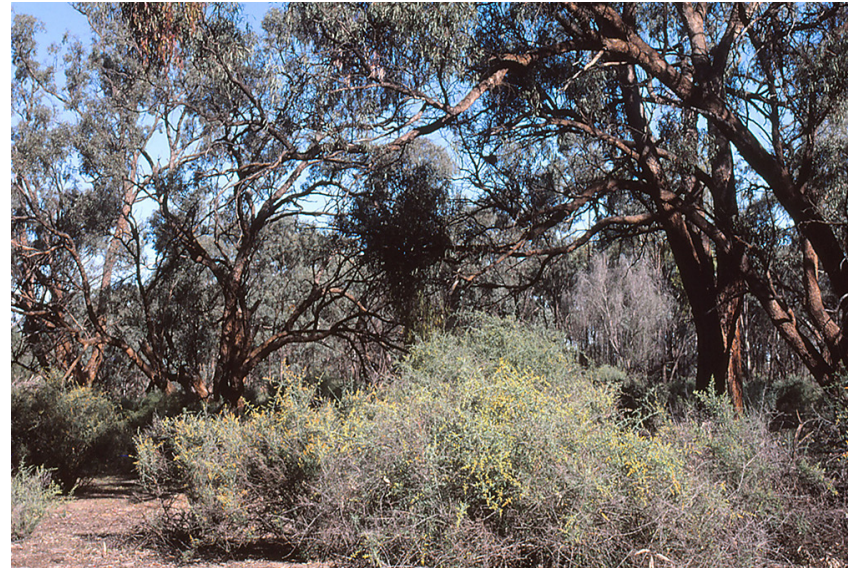

Fig. 31. Community 23, Eucalyptus largiflorens-Muehlenbeckia florulenta-Chenopodium nitrariaceum woodland, in MurrayKulkyne Regional Park in Section 5, with an understorey dominated by Chenopodium nitrariaceum.

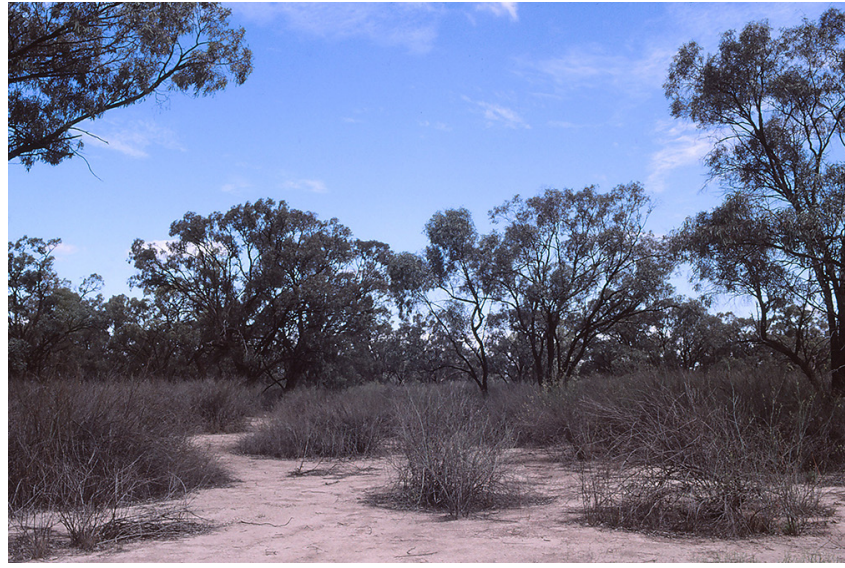

Fig. 32. Community 24, Eucalyptus largiflorens-Muehlenbeckia florulenta-Atriplex semibaccata woodland, at Katarapko Creek in Section 6, with an understorey dominated by Muehlenbeckia florulenta.

Mean number of species per plot (including unidentified): 21.7 (range 14-27)

Mean number of native species per plot: 14.3 (range 7-23)

Mean number of exotic species per plot: 7.3 (range 3-13)

Mean percentage of chenopod species per plot: $22 \%$

Black Box condition: 70\% healthy, $22 \%$ unhealthy, $8 \%$ dead $(n=120)$

Black Box regeneration: 6 per ha $(0<1 \mathrm{~m}, 67 \% 1-4 \mathrm{~m}, 33 \%>4 \mathrm{~m})$

Mean grazing index (number of dropping clusters per $20 \mathrm{~m}$ ): 12.23 (sheep 0.62, cattle 0.46, horse 0.15, rabbit 10.19, pig 0.04, kangaroo 0.77)

Distribution: All plots in South Australia, in Sections 6 (5 plots) and 7 (8 plots). A common floodplain community in the inner parts of the Black Box zone. The South Australian equivalent of Community 23 from NSW and Victoria.

\section{Eucalyptus largiflorens - Melaleuca lanceolata - Allocasuarina luehmannii woodland (Fig. 33)}

Layer Height (m) $\quad$ Foliage cover (\%) Main species

Tree

Tall shrub

Low shrub

Herb
13

7

0.4

0.2
15

5

30

70

Number of plots: 2

Eucalyptus largiflorens

Melaleuca lanceolata, Allocasuarina luehmannii, Hakea tephrosperma Sclerolaena muricatus

*Hordeum murinum, *Vulpia myuros, *Schismus barbatus, Austrostipa nodosa, Austrodanthonia caespitosa, Atriplex leptocarpa, Einadia nutans, *Sisymbrium erysimoides

Mean number of species per plot (including unidentified): 21 (range 20-22)

Mean number of native species per plot: 11.5 (range 11-12)

Mean number of exotic species per plot: 9.5 (range 9-10)

Mean percentage of chenopod species per plot: $14 \%$

Black Box condition: 70\% healthy, 30\% unhealthy, 0 dead $(n=20)$

Black Box regeneration: None in the plots

Mean grazing index (number of dropping clusters per $20 \mathrm{~m}$ ): 7.75 (sheep 4.5, cattle 0.75 , rabbit 1.5, kangaroo 1)

Distribution: Both plots in NSW, in Thule State Forest in Section 4, where it was found in and beside Green Gully, which was the former course of the Murray before the uplift of the Cadell Fault (Bowler 1978).

Notes: This community appears to be a marginal floodplain remnant of an Allocasuarina luehmannii (Buloke) community that originally covered the adjacent rise but has been cleared except for a few remnant Buloke trees. Most of the original extent of Buloke vegetation on rises in Section 4 has long been cleared (Smith et al. 1943). In the sample plot in Green Gully itself there were many old dead Eucalyptus camaldulensis trees, indicating that it was formerly a River Red Gum community. 


\section{Eucalyptus largiflorens - Melaleuca lanceolata - Atriplex rhagodioides woodland (Fig. 34)}

\begin{tabular}{|c|c|c|c|}
\hline Layer & Height (m) & Foliage cover $(\%)$ & Main species \\
\hline Tree & 9 & 10 & Eucalyptus largiflorens \\
\hline Tall shrub & 7 & 50 & Melaleuca lanceolata \\
\hline Mid shrub & 1.5 & 5 & Atriplex rhagodioides \\
\hline Low shrub & 0.4 & 20 & Enchylaena tomentosa, Maireana brevifolia \\
\hline Herb & 0.1 & 20 & $\begin{array}{l}\text { Atriplex lindleyi, *Sonchus oleraceus, *Hordeum murinum, Disphyma crassifolium, } \\
\text { Einadia nutans, *Vulpia myuros, Crassula sieberiana, *Reichardia tingitana }\end{array}$ \\
\hline
\end{tabular}

Number of plots: 3

Mean number of species per plot (including unidentified): 25.7 (range 24-28)

Mean number of native species per plot: 17 (range 14-19)

Mean number of exotic species per plot: 8.7 (range 6-10)

Mean percentage of chenopod species per plot: $30 \%$

Black Box condition: $43 \%$ healthy, $57 \%$ unhealthy, 0 dead $(n=30)$

Black Box regeneration: None in the plots

Mean grazing index (number of dropping clusters per 20 m): 14.33 (sheep 6, rabbit 6, kangaroo 2.33)

Distribution: All plots in South Australia, in Section 6. Typically found in infrequently flooded sites on reddish, rather sandy soils.

\section{Eucalyptus largiflorens - Atriplex nummularia open-woodland (Fig. 35)}

\begin{tabular}{|c|c|c|c|}
\hline Layer & Height (m) & Foliage cover $(\%)$ & Main species \\
\hline Tree & 7 & $5 / 0$ & Eucalyptus largiflorens or absent \\
\hline Shrub & 1 & 15 & $\begin{array}{l}\text { Atriplex nummularia, Rhagodia spinescens, Enchylaena tomentosa, Maireana } \\
\text { pyramidata }\end{array}$ \\
\hline Herb & 0.1 & 55 & $\begin{array}{l}\text { *Schismus barbatus, *Vulpia myuros, Atriplex lindleyi, *Medicago polymorpha, } \\
\text { Brachyscome lineariloba, *Hordeum murinum, *Bromus rubens, Plantago } \\
\text { drummondii }\end{array}$ \\
\hline
\end{tabular}

Number of plots: 4

Mean number of species per plot (including unidentified): 32.3 (range 29-35)

Mean number of native species per plot: 21.5 (range 17-25)

Mean number of exotic species per plot: 10.3 (range 9-14)

Mean percentage of chenopod species per plot: $29 \%$

Black Box condition: $70 \%$ healthy, $25 \%$ unhealthy, $5 \%$ dead $(n=20)$

Black Box regeneration: None in the plots

Mean grazing index (number of dropping clusters per $\mathbf{2 0} \mathbf{~ m}$ ): 8 (sheep 4.5, cattle 0.13, rabbit 3.13, kangaroo 0.25)

Distribution: NSW (1 plot) and Victoria (3 plots), in Sections 5 (1 plot) and 6 (3 plots). Outer, less frequently flooded parts of the Black Box zone.

\section{Eucalyptus largiflorens - Atriplex rhagodioides woodland (Fig. 36)}

Layer Height (m) Foliage cover (\%) Main species

$\begin{array}{llll}\text { Tree } & 8 & 15 & \text { Eucalyptus largiflorens } \\ \text { Shrub } & 1 & 30 & \text { Atriplex rhagodioides, Enchylaena tomentosa, some Atriplex nummularia } \\ \text { Herb } & 0.1 & 15 & \text { Crassula colorata, Einadia nutans, Disphyma crassifolium, *Sonchus oleraceus, } \\ & & \text { Actinobole uliginosum, Calotis hispidula, *Vulpia myuros, *Schismus barbatus }\end{array}$

Number of plots: 11 (including 3 badly salt-affected plots not used for the description and statistics)

Mean number of species per plot (including unidentified): 22.8 (range 7-35)

Mean number of native species per plot: 17.5 (range 7-25)

Mean number of exotic species per plot: 5.3 (range $0-11$ )

Mean percentage of chenopod species per plot: $24 \%$

Black Box condition: 53\% healthy, 34\% unhealthy, 13\% dead $(n=85)$

Black Box regeneration: 103 per ha $(6 \%<1 \mathrm{~m}, 64 \% 1-4 \mathrm{~m}, 30 \%>4 \mathrm{~m})$

Mean grazing index (number of dropping clusters per 20 m): 9.38 (sheep 1.13, horse 0.13, rabbit 7, kangaroo 1.13)

Distribution: All plots in South Australia, in Section 6. Outer, less frequently flooded parts of the Black Box zone. The South Australian equivalent of Community 27 from NSW and Victoria. 


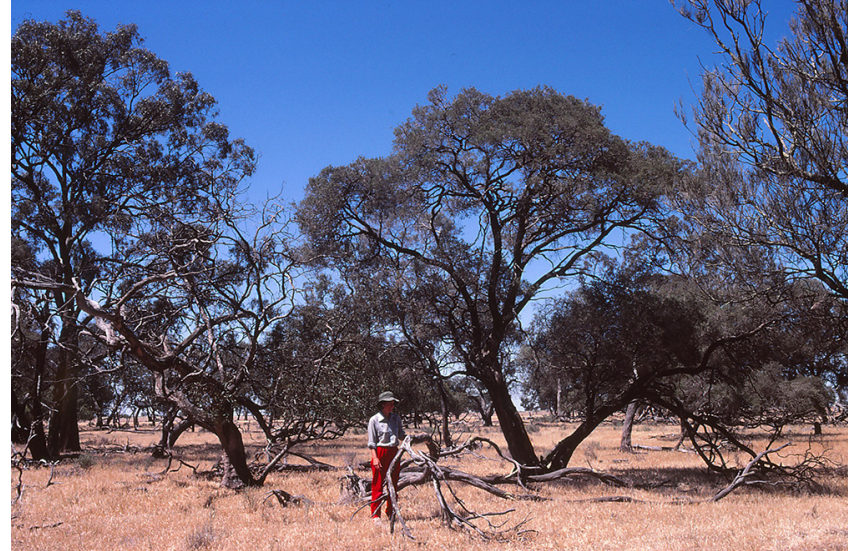

Fig. 33. Community 25, Eucalyptus largiflorens-Melaleuca lanceolata-Allocasuarina luehmannii woodland, in Thule State Forest in Section 4.

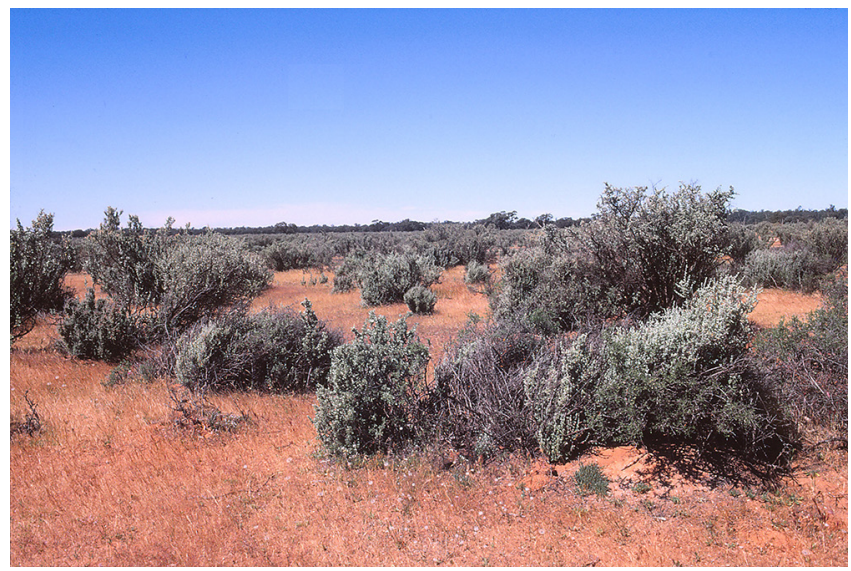

Fig. 35. Community 27, Eucalyptus largiflorens- Atriplex nummularia open-woodland, near Colignan in Section 5, with a shrub layer of Atriplex nummularia and Rhagodia spinescens and no tree layer.

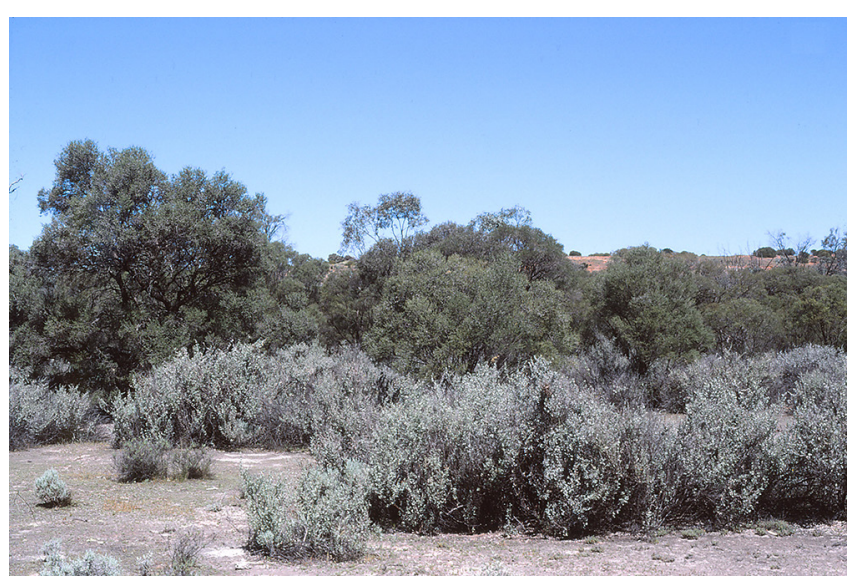

Fig. 34. Community 26, Eucalyptus largiflorens-Melaleuca lanceolata-Atriplex rhagodioides woodland, near Murtho in Section 6.

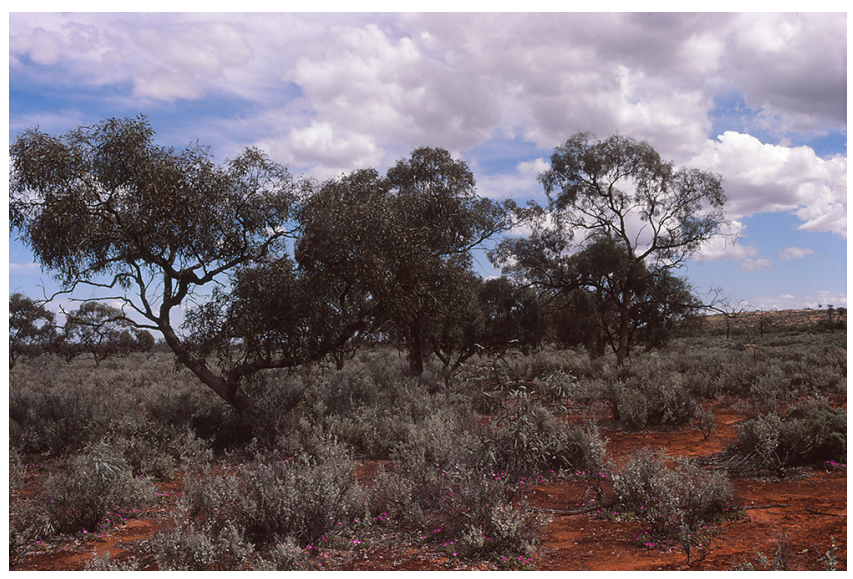

Fig. 36. Community 28, Eucalyptus largiflorens- Atriplex rhagodioides woodland, near Calperum in Section 6, with a shrub layer dominated by Atriplex rhagodioides.

\section{Chenopodium nitrariaceum - Muehlenbeckia florulenta shrubland (Fig. 37)}

$\begin{array}{llll}\text { Layer } & \text { Height }(\mathbf{m}) & \text { Foliage cover }(\boldsymbol{\%}) \text { Main species } \\ \text { Tall shrub } & 1.5 & 15 & \begin{array}{l}\text { Chenopodium nitrariaceum, Muehlenbeckia florulenta } \\ \text { Low shrub }\end{array} \\ \text { Herb } & 0.3 & 10 & \begin{array}{l}\text { Sclerolaena tricuspis } \\ \text { Sclerolaena brachyptera, *Vulpia myuros, Brachyscome lineariloba, Atriplex }\end{array} \\ & 0.1 & 40 & \begin{array}{l}\text { lindleyi, Calocephalus sonderi, } \\ \text { nutans }\end{array}\end{array}$

Number of plots: 6

Mean number of species per plot (including unidentified): 30 (range 18-44)

Mean number of native species per plot: 23.3 (range 15-35)

Mean number of exotic species per plot: 6.5 (range 2-9)

Mean percentage of chenopod species per plot: $28 \%$

Mean grazing index (number of dropping clusters per 20 m): 26.58 (sheep 4.17, cattle 0.17, rabbit 20.33, kangaroo 1.92)

Distribution: NSW (observed), Victoria (5 plots) and South Australia (1 plot), in Sections 4 (observed), 5 (4 plots) and 6 (2 plots). Found in the inner parts of the Black Box zone, typically in association with Community 23.

Notes: The dominant species may be either Chenopodium nitrariaceum or Muehlenbeckia florulenta or a mixture of the two.

\section{Muehlenbeckia florulenta - Tecticornia pergranulata shrubland}




$\begin{array}{llll}\text { Layer } & \text { Height }(\mathbf{m}) & \text { Foliage cover }(\%) \text { Main species } \\ \text { Tall shrub } & 1.6 & 20 & \text { Muehlenbeckia florulenta, some Atriplex rhagodioides } \\ \text { Low shrub } & 0.3 & 15 & \text { Tecticornia pergranulata, } \text { T. indica, Sclerolaena tricuspis, Enchylaena tomentosa } \\ \text { Herb } & 0.2 & 25 & \text { Atriplex lindleyi, A. leptocarpa, Sporobolus mitchellii, Atriplex semibaccata, } \\ & & & \text { *Schismus barbatus, Einadia nutans, } \text { *Hordeum murinum, } \text { *Spergularia rubra }\end{array}$

Number of plots: 6

Mean number of species per plot (including unidentified): 26.3 (range 9-36)

Mean number of native species per plot: 16.3 (range 5-23)

Mean number of exotic species per plot: 10 (range 4-14)

Mean percentage of chenopod species per plot: $28 \%$

Mean grazing index (number of dropping clusters per 20 m): 10.58 (sheep 0.33, rabbit 9.75, kangaroo 0.5)

Distribution: All plots in South Australia, in Sections 6 (4 plots) and 7 ( 2 plots). Found in saline sites, both on the floodplain and on the banks of saline water bodies. The South Australian equivalent of Community 29, which mainly occurs in Victoria and NSW.

Notes: Although this appears to be a natural community of saline depressions in the Black Box zone, four of the plots contained dead Eucalyptus camaldulensis trees (one of these also contained dead E. largiflorens trees), suggesting that they were former River Red Gum vegetation that had succumbed to increasing salinisation. The latter plots tended to have less Muehlenbeckia and more Tecticornia. The only eucalypt regeneration in the plots was a single E. largiflorens sapling.

\section{Atriplex vesicaria - Tecticornia triandra shrubland}

\begin{tabular}{|c|c|c|c|}
\hline Layer & Height (m) & Foliage cover $(\%)$ & Main species \\
\hline Shrub & 0.4 & 20 & Atriplex vesicaria, Tecticornia triandra, Sclerolaena tricuspis \\
\hline Herb & 0.1 & 35 & $\begin{array}{l}\text { *Vulpia myuros, Disphyma crassifolium, Brachyscome lineariloba, Bromus arenarius, } \\
\text { Pogonolepis muelleriana, Actinobole uliginosum, Sclerolaena brachyptera, Crassula } \\
\text { colorata }\end{array}$ \\
\hline
\end{tabular}

Number of plots: 5

Mean number of species per plot (including unidentified): 21.6 (range 17-26)

Mean number of native species per plot: 15.8 (range 12-19)

Mean number of exotic species per plot: 5.6 (range 3-9)

Mean percentage of chenopod species per plot: $25 \%$

Mean grazing index (number of dropping clusters per 20 m): 8.8 (sheep 3.6, cattle 0.1, horse 0.1, rabbit 3.7, kangaroo 1.3)

Distribution: NSW (2 plots), Victoria (2 plots) and South Australia (1 plot), in Sections 5 (1 plot at the far western end) and 6 (4 plots). Found in the outer, less frequently flooded parts of the Black Box zone, typically in association with Communities 27 and 28 . Atriplex vesicaria shrubland was also once common in Section 4, but overgrazing has led to its replacement by Nitraria billardierei shrubland (Smith et al. 1943, Beadle 1948). The latter, highly derivative community was not sampled during this survey.

Notes: Varies from stands dominated by Atriplex vesicaria to stands dominated by Tecticornia triandra, although usually a mixture of both species. Tecticornia triandra, an unpalatable samphire, is presumably favoured by higher salinity levels and heavy grazing, compared with the much more palatable Atriplex vesicaria.

\section{Tecticornia pergranulata - T. indica shrubland (Fig. 38)}

$\begin{array}{llll}\text { Layer } & \text { Height }(\mathbf{m}) & \text { Foliage cover }(\boldsymbol{\%}) \text { Main species } \\ \text { Shrub } & 0.2 & 35 & \text { Tecticornia pergranulata, T. indica, Sclerolaena tricuspis } \\ \text { Herb } & 0.1 & 10 & \text { Disphyma crassifolium, Atriplex lindleyi, Senecio glossanthus, } * \text { Hordeum murinum, } \\ \text { Number of plots: } 5 & & & \text { *Parapholis incurva, Cressa australis, *Bromus rubens }\end{array}$

Number of plots: 5

Mean number of species per plot (including unidentified): 12 (range 4-29)

Mean number of native species per plot: 7.6 (range 4-14)

Mean number of exotic species per plot: 4.2 (range 0-15)

Mean percentage of chenopod species per plot: $37 \%$

Mean grazing index (number of dropping clusters per 20 m): 1.6 (sheep 0.1, cattle 0.1, rabbit 1.4)

Distribution: NSW (observed), Victoria (observed) and South Australia (plots), in Sections 4 to 8, but only sampled in Sections 6 (2 plots) and 7 ( 3 plots). Found in highly saline sites, often with salt crusting on the surface. Occurs in both the Black Box and River Red Gum zones, typically in depressions or on the edges of wetlands.

Notes: All plots were in sites that were formerly eucalypt communities, as indicated by the presence of dead trees and stumps. Although this community probably occurs naturally on the floodplain, the majority of occurrences are the result of increasing salinisation from irrigation activities. There was no eucalypt regeneration in any of the plots. 


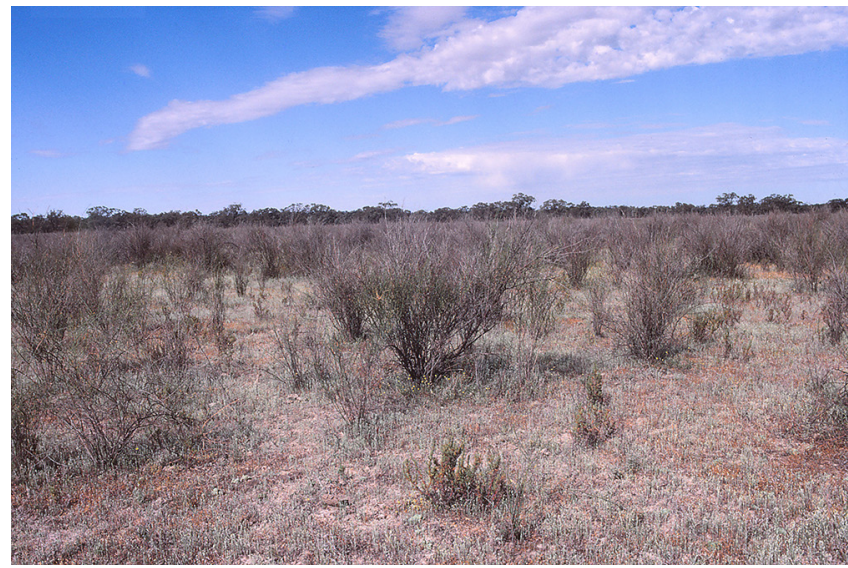

Fig. 37. Community 29, Chenopodium nitrariaceum-

Muehlenbeckia florulenta shrubland, in Belsar Island State Forest in Section 5, dominated by Muehlenbeckia florulenta.

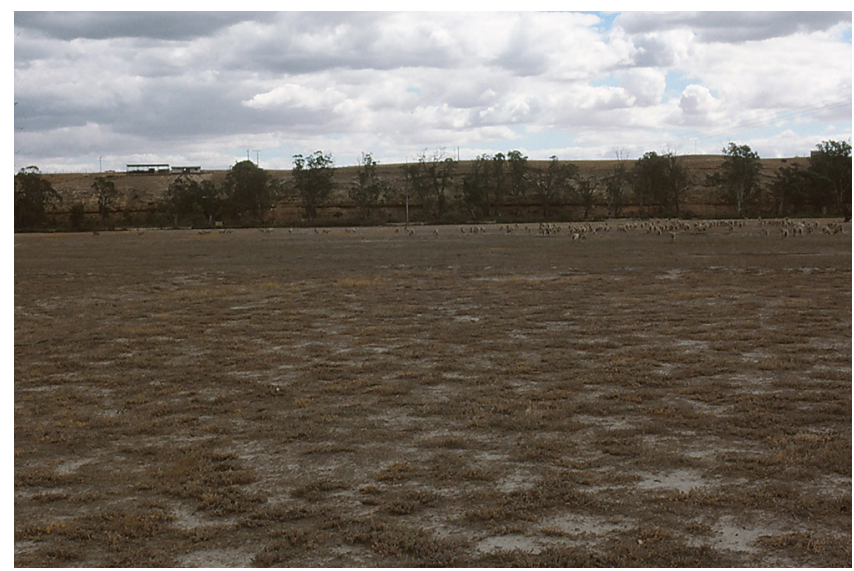

Fig. 39. Community 33, Sporobolus mitchellii-Atriplex leptocarpa grassland, at McBean Pound in Section 7.

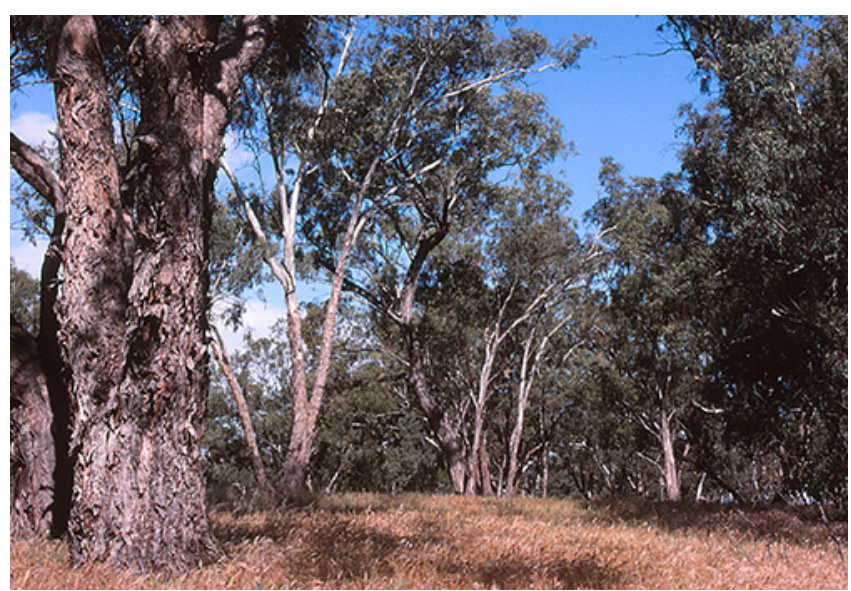

Fig. 41. Community 35, Eucalyptus melliodora woodland, near Yarrawonga Weir in Section 1.

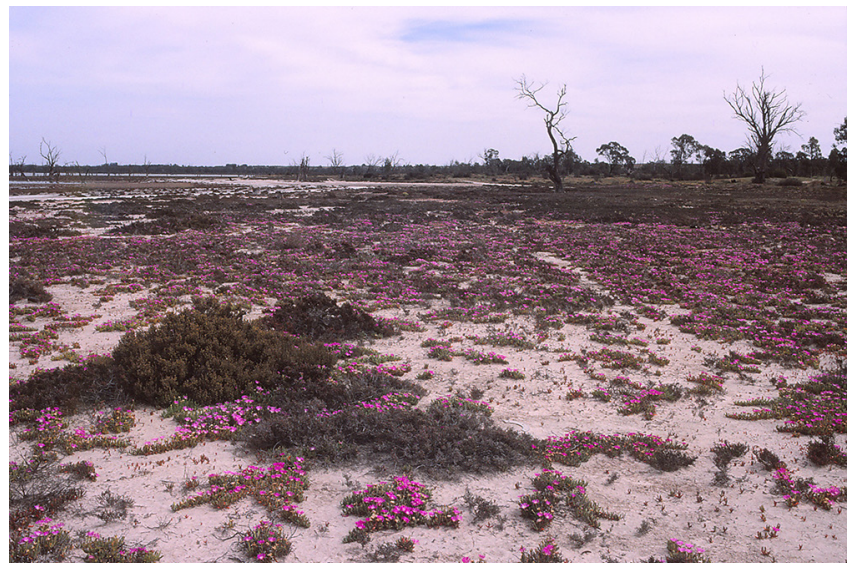

Fig. 38. Community 32 , Tecticornia pergranulata-T. indica shrubland, near Waikerie in Section 7, dominated by Tecticornia pergranulata and Disphyma crassifolium.

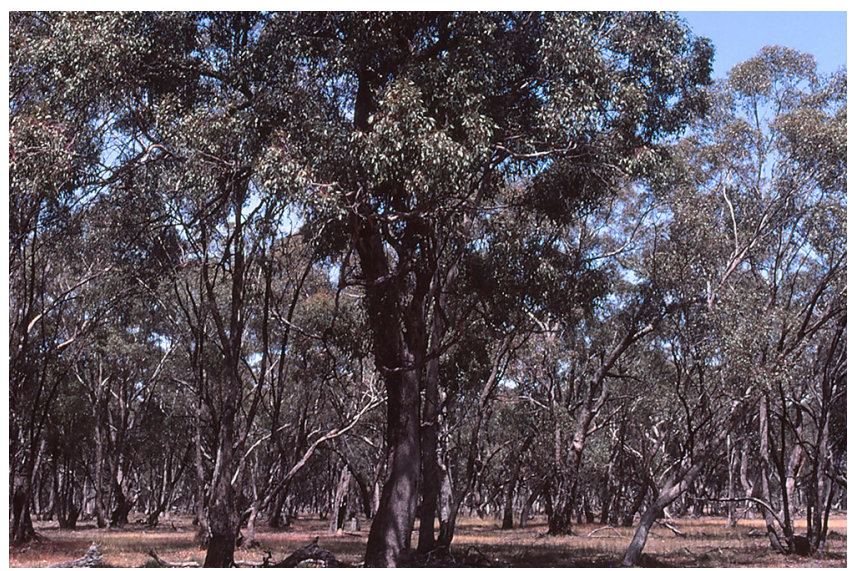

Fig. 40. Community 34, Eucalyptus microcarpa open-forest, on Ulupna Island in Section 2.

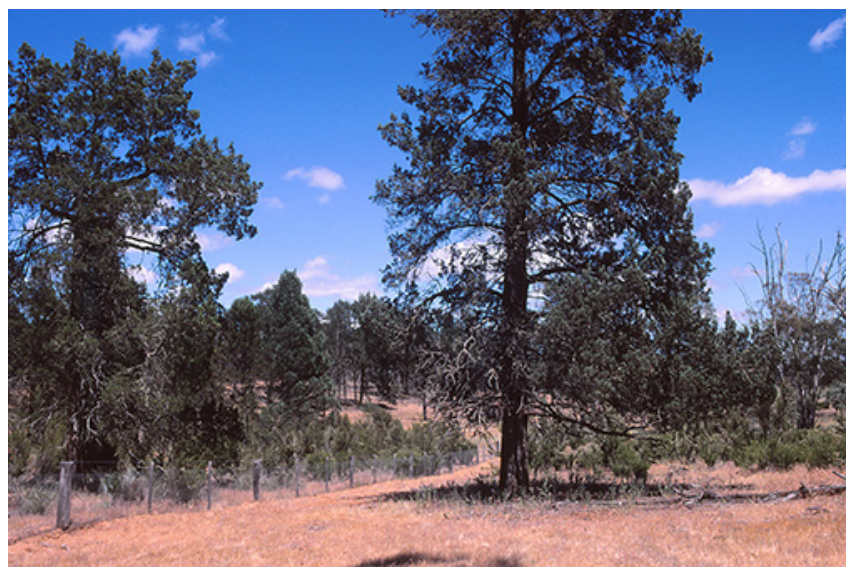

Fig. 42. Community 36, Callitris glaucophylla woodland, in Millewa State Forest in Section 3. 


\section{Sporobolus mitchellii - Atriplex leptocarpa grassland (Fig. 39)}

\begin{tabular}{|c|c|c|c|}
\hline Layer & Height (m) & Foliage cover $(\%)$ & Main species \\
\hline Shrub & 1 & 1 & Muehlenbeckia florulenta \\
\hline Tall herb & 0.4 & 5 & $\begin{array}{l}\text { *Dittrichia graveolens, Cyperus gymnocaulos, *Lactuca saligna, *Cirsium vulgare, } \\
\text { Sonchus hydrophilus, *Aster subulatus }\end{array}$ \\
\hline Herb & 0.1 & 45 & $\begin{array}{l}\text { Sporobolus mitchellii, Atriplex leptocarpa, *Spergularia rubra, Lachnagrostis } \\
\text { filiformis, *Sonchus oleraceus, Euchiton sphaericus, *Asphodelus fistulosus }\end{array}$ \\
\hline
\end{tabular}

Number of plots: 2

Mean number of species per plot (including unidentified): 13.5 (range 11-16)

Mean number of native species per plot: 7 (range 6-8)

Mean number of exotic species per plot: 6.5 (range 5-8)

Mean percentage of chenopod species per plot: $19 \%$

Mean grazing index (number of dropping clusters per $20 \mathrm{~m}$ ): 13.75 (sheep 13, cattle 0.5, kangaroo 0.25)

Distribution: Victoria (Ashwell 1987) and South Australia (plots), in Sections 6 (Ashwell 1987) and 7 (plots). Sporobolus mitchellii grasslands occur naturally in the Black Box zone, but may also result from clearing or overgrazing.

\section{RISES WITHIN THE FLOODPLAIN}

\section{Eucalyptus microcarpa open-forest (Fig. 40)}

$\begin{array}{llll}\text { Layer } & \text { Height }(\mathbf{m}) & \text { Foliage cover }(\boldsymbol{\%}) \text { Main species } \\ \text { Tree } & 17 & 55 & \text { Eucalyptus microcarpa } \\ \text { Shrub } & 1.5 & 20 / 0 & \text { Acacia acinacea } \text { or absent } \\ \text { Herb } & 0.2 & 75 & \text { *Lolium perenne x rigidum, Carex inversa, *Trifolium campestre, } * \text { Bromus } \\ & & & \text { diandrus, } * \text { B. madritensis, } * \text { Trifolium striatum, Juncus flavidus, Einadia nutans }\end{array}$

Number of plots: 2

Mean number of species per plot (including unidentified): 37 (range 36-38)

Mean number of native species per plot: 15.5 (range 15-16)

Mean number of exotic species per plot: 21.5 (range 21-22)

Mean percentage of chenopod species per plot: $3 \%$

Grey Box condition: $75 \%$ healthy, $22 \%$ unhealthy, $3 \%$ dead $(n=32)$

Grey Box regeneration: 625 per ha $(8 \%<1 \mathrm{~m}, 28 \% 1-4 \mathrm{~m}, 64 \%>4 \mathrm{~m})$

Mean grazing index (number of dropping clusters per 20 m): 3.5 (kangaroo 3.5)

Distribution: Victoria, in Sections 2 (plots) and 3 (Chesterfield 1986). Apparently associated with higher ground that is rarely, if ever, flooded.

\section{Eucalyptus melliodora woodland (Fig. 41)}

$\begin{array}{llll}\text { Layer } & \text { Height }(\mathbf{m}) & \text { Foliage cover }(\boldsymbol{\%}) \text { Main species } \\ \text { Tree } & 18 & 30 & \text { Eucalyptus melliodora, occasional E. camaldulensis and Allocasuarina luehmannii } \\ \text { Herb } & 0.2 & 85 & * \text { Bromus diandrus, }{ }^{*} \text { Bromus hordeaceus, *Vulpia bromoides, *V. myuros, } \\ & & & * \text { Trifolium arvense, } * \text { T. campestre, Austrostipa nodosa, } \text { *Lolium perenne } x \text { rigidum }\end{array}$

Number of plots: 4

Mean number of species per plot (including unidentified): 31.8 (range 24-44)

Mean number of native species per plot: 12.8 (range 8-18)

Mean number of exotic species per plot: 18.8 (range 12-26)

Mean percentage of chenopod species per plot: $3 \%$

Yellow Box condition: 100\% healthy, 0 unhealthy, 0 dead $(n=40)$

Yellow Box regeneration: 56 per ha $(0<1 \mathrm{~m}, 56 \% 1-4 \mathrm{~m}, 44 \%>4 \mathrm{~m})$

Mean grazing index (number of dropping clusters per 20 m): 18.75 (cattle 2.13, rabbit 15, kangaroo 1.63)

Distribution: NSW (3 plots) and Victoria (1 plot), in Sections 1 (1 plot) and 3 ( 3 plots). Apparently associated with higher ground that is rarely, if ever, flooded. Soils tend to have a moderate to high sand content. 


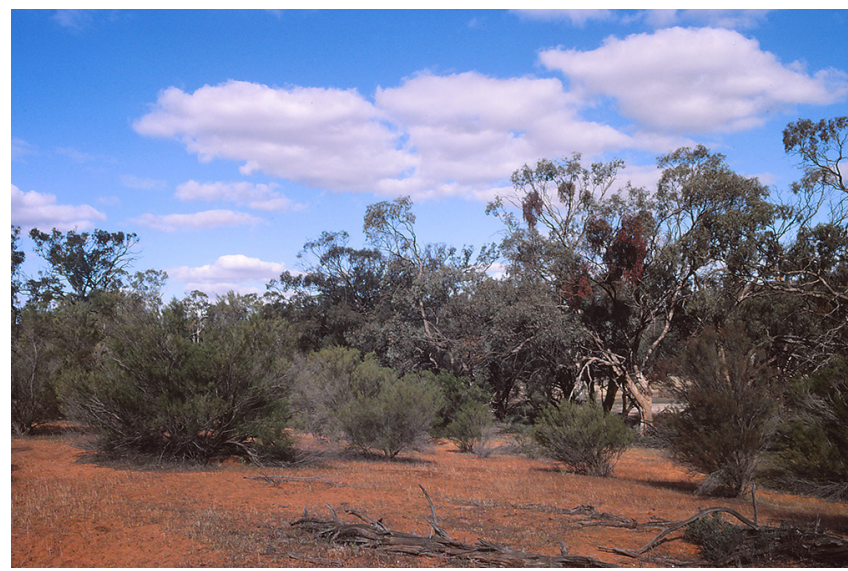

Fig. 43. Community 37, Dodonaea viscosa-Callitris gracilis shrubland, in Hattah-Kulkyne National Park in Section 5, dominated by Dodonaea viscosa ssp. angustissima.

\section{Callitris glaucophylla woodland (Fig. 42)}

$\begin{array}{llll}\text { Layer } & \text { Height }(\mathbf{m}) & \text { Foliage cover }(\boldsymbol{\%}) \text { Main species } \\ \text { Tree } & 13 & 20 & \text { Callitris glaucophylla } \\ \text { Shrub } & 1.3 & 30 / 0 & \text { Calytrix tetragona or absent } \\ \text { Herb } & 0.2 & 60 & * \text { Vulpia myuros, Bromus rubens, *B. diandrus, Pentaschistis airoides, *Echium } \\ & & & \text { plantagineum, } * \text { Trifolium arvense, }{ }^{*} \text { Schismus barbatus, *Hypochaeris glabra }\end{array}$

Number of plots: 3

Mean number of species per plot (including unidentified): 27.3 (range 18-33)

Mean number of native species per plot: 10 (range 1-15)

Mean number of exotic species per plot: 17.3 (range 16-19)

Mean percentage of chenopod species per plot: $4 \%$

White Cypress Pine condition: 87\% healthy, 3\% unhealthy, 10\% dead $(\mathrm{n}=30)$

White Cypress Pine regeneration: 58 per ha $(29 \%<1 \mathrm{~m}, 71 \% 1-4 \mathrm{~m}, 0>4 \mathrm{~m})$

Mean grazing index (number of dropping clusters per 20 m): 30.83 (cattle 3.17, rabbit 25, kangaroo 2.67)

Distribution: All plots in NSW, in Section 3. Found on reddish sandy soils on floodplain sand dunes, apparently above flood levels.

Notes: Callitris gracilis may also occur in this community but was not encountered at the few sites sampled by us. The plots were all on relatively well vegetated sand dunes. Many other dunes now have only a thin herb layer with few, if any, trees and shrubs, and are often badly eroded.

\section{Dodonaea viscosa - Callitris gracilis shrubland (Fig. 43)}

$\begin{array}{llll}\text { Layer } & \text { Height }(\mathbf{m}) & \text { Foliage cover }(\%) \text { Main species } \\ \text { Tree } & 8 & 10 / 0 & \text { Callitris gracilis ssp. murrayensis, but mostly absent } \\ \text { Shrub } & 2 & 20 & \begin{array}{l}\text { Dodonaea viscosa } \\ \text { Herb }\end{array} \\ & 0.1 & 30 & \begin{array}{l}\text { *Vulpia myuros, Bromus rubens, *Hypochaeris glabra, *Pentaschistis airoides, } \\ \text { Actinobole uliginosum, Austrodanthonia caespitosa, Myriocephalus rhizocephalus, }\end{array}\end{array}$

\section{Number of plots: 3}

*Schismus barbatus

Mean number of species per plot (including unidentified): 23.7 (range 16-28)

Mean number of native species per plot: 14.3 (range 10-19)

Mean number of exotic species per plot: 8 (range 5-11)

Mean percentage of chenopod species per plot: $5 \%$

Mean grazing index (number of dropping clusters per 20 m): 22.33 (rabbit 15, kangaroo 7.33)

Distribution: Victoria, in Sections 5 (plots) and 6 (Ashwell 1987). Found on reddish sandy soils on floodplain sand dunes, apparently above flood levels.

Notes: The original dominants in this community were probably Callitris gracilis, Hakea leucoptera, Eremophila longifolia and Alectryon oleifolius (Zimmer 1937), but the most common shrub encountered now is Dodonaea viscosa ssp. angustissima, a native 'woody weed'. Many dunes are badly eroded and often the only vegetation is a sparse herb layer. 


\section{Appendix 2. Two-way classification of Murray riparian communities and common plant species}

Communities numbered as in Appendix $1 .{ }^{*}=$ exotic species, $\mathrm{U}=$ uncommon, $\mathrm{M}=$ moderately common, $\mathrm{C}=$ common, thick lines indicate a major division, thin lines indicate a minor division

Species

\section{Community}

$3635341641914133106 \quad 5 \quad 2 \quad 221 \quad 2021117 \quad 8 \quad 9 \quad 15172529233330242618123728312732$

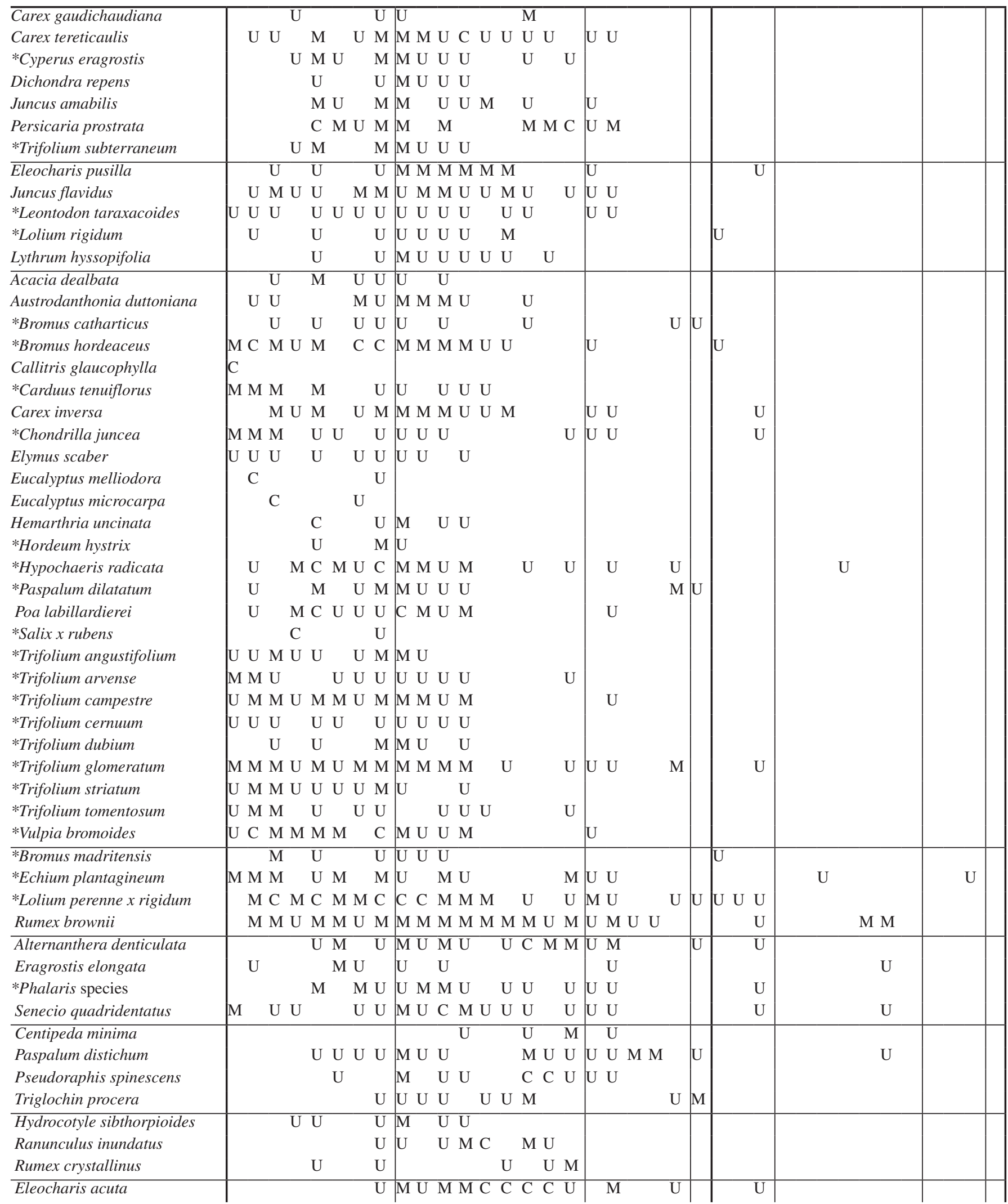


Species

\section{Community}

$3635341641914133106 \quad 5 \quad 2 \quad 2212021117 \quad 8 \quad 9 \quad 15172529233330242618123728312732$

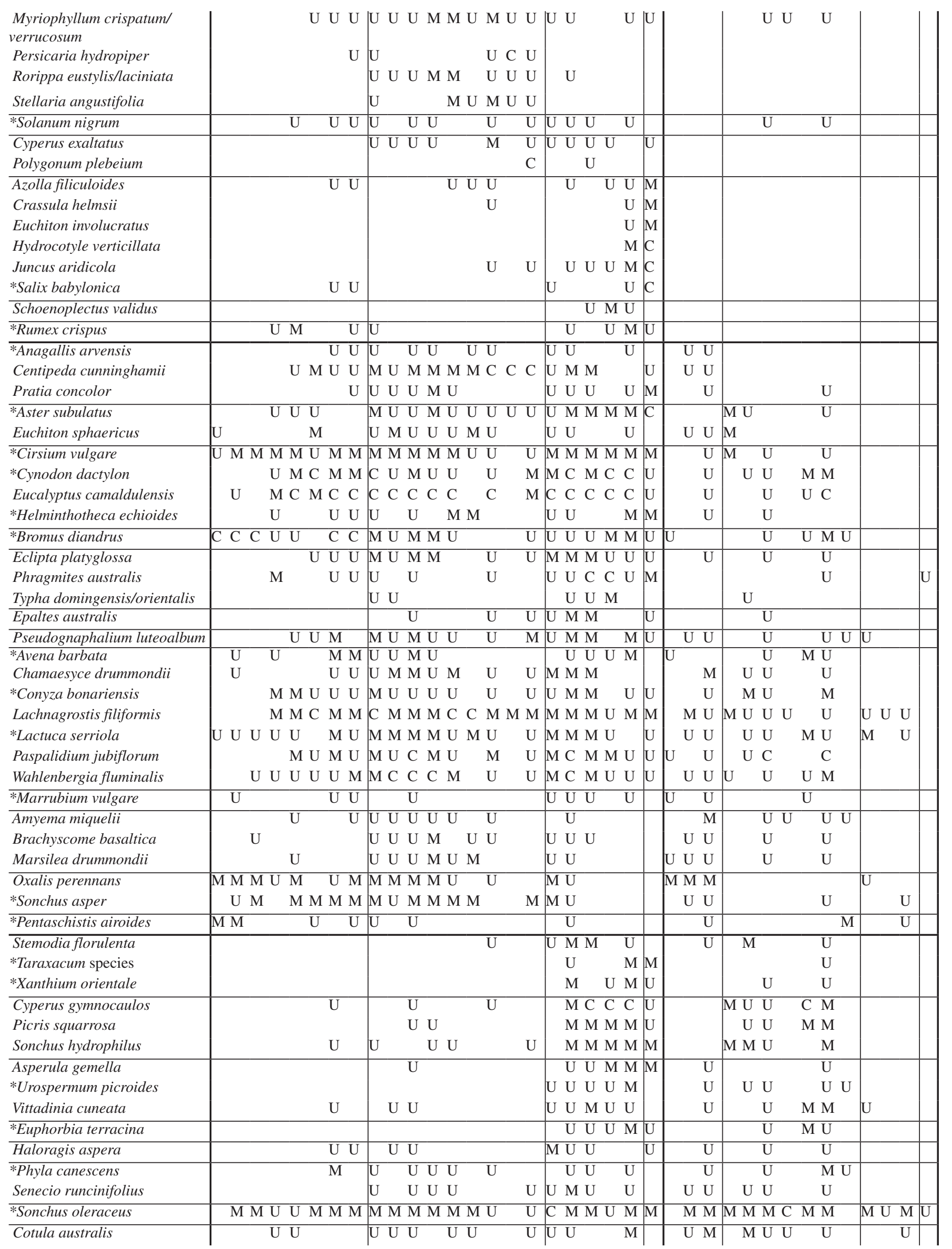




\section{Species}

\section{Community}

$3635341641914133106 \quad 5 \quad 2 \quad 221 \quad 2021117 \quad 8 \quad 9 \quad 15172529233330242618123728312732$

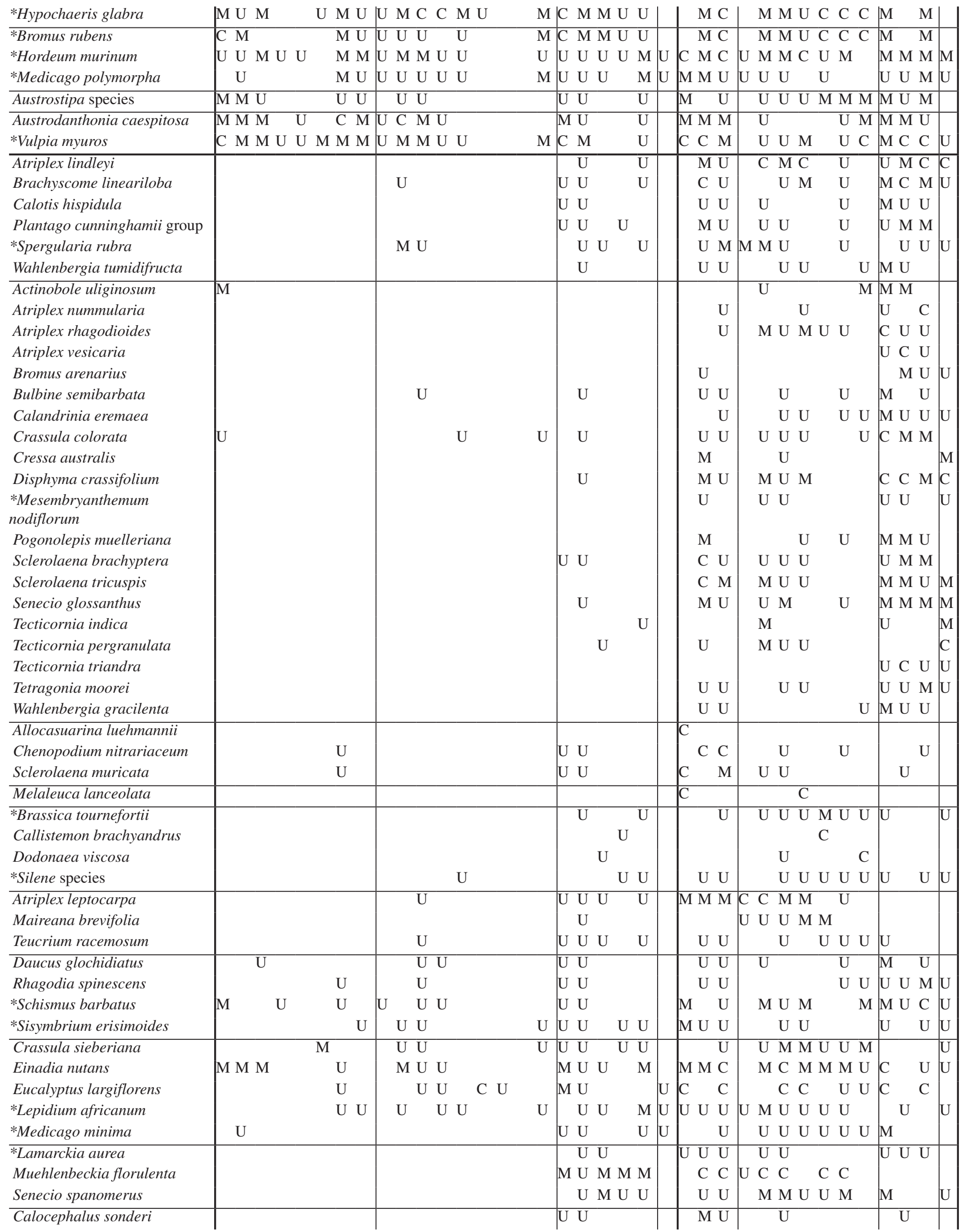


Species

\section{Community}

$3635341641914133106 \quad 5 \quad 2 \quad 2212021117 \quad 8 \quad 9 \quad 15172529233330242618123728312732$

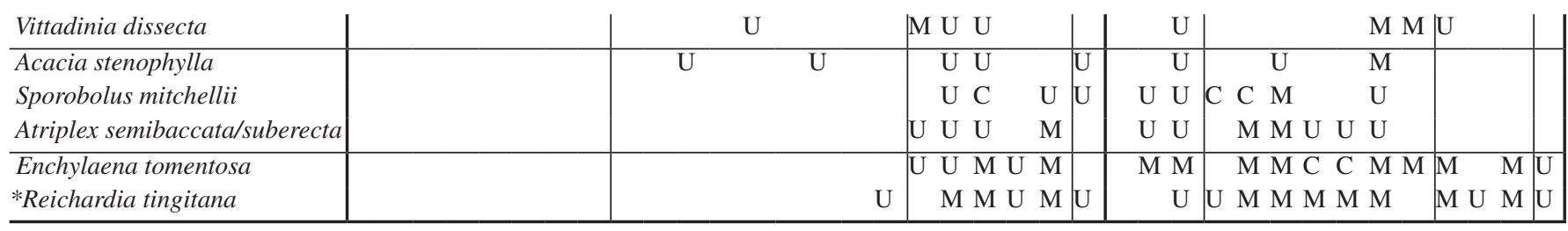




\section{Appendix 3. Plant species recorded in the survey plots}

* =exotic species

Species

\section{FERNS}

Azollaceae

Azolla filiculoides

Azolla pinnata

Marsileaceae

Marsilea costulifera

Marsilea drummondii

\section{CONIFERS}

Cupressaceae

Callitris glaucophylla

Callitris gracilis ssp. murrayensis

\section{DICOTYLEDONS}

\section{Aizoaceae}

Carpobrotus modestus

Disphyma crassifolium

Glinus lotoides

*Mesembryanthemum crystallinum

*Mesembryanthemum nodiflorum

Tetragonia moorei

Amaranthaceae

Alternanthera denticulata

Alternanthera nodiflora

*Alternanthera pungens

Anacardiaceae

*Schinus areira

Apiaceae

*Ammi majus

*Berula erecta

Daucus glochidiatus

*Foeniculum vulgare

Hydrocotyle laxiflora

Hydrocotyle sibthorpioides

Hydrocotyle verticillata

Lilaeopsis polyantha

Asteraceae

Actinobole uliginosum

*Arctotheca calendula

*Aster subulatus

Brachyscome basaltica var. gracilis

Brachyscome ciliaris var. lanuginosa

Brachyscome lineariloba

Calocephalus sonderi

Calotis cuneifolia

Calotis hispidula

Calotis scabiosifolia

Calotis scapigera

* Carduus tenuiflorus

* Carthamus lanatus

* Centaurea melitensis

Centipeda cunninghamii

Centipeda minima

*Chondrilla juncea

Chrysocephalum apiculatum

*Cirsium vulgare

* Conyza bonariensis

Cotula australis

* Cotula bipinnata

* Cotula coronopifolia

Craspedia variabilis

Cymbonotus lawsonianus

*Dittrichia graveolens

Eclipta platyglossa

Epaltes australis

Euchiton gymnocephalus
State River section Vegetation zone

$\begin{array}{lllllllllllll}\text { NSW Vic } & \text { SA } & 1 & 2 & 3 & 4 & 5 & 6 & 7 & 8 & \text { RedGm } & \text { BlkBx } & \text { Rises }\end{array}$

$\begin{array}{lllllllllllll}\mathrm{N} & \mathrm{V} & \mathrm{S} & 1 & & 3 & 4 & & 6 & 7 & 8 & \mathrm{G} & \\ \mathrm{N} & \mathrm{V} & & & 2 & & & & & & & \mathrm{G} & \\ & & & & & & & & & & & & \\ \mathrm{N} & \mathrm{V} & & & & 3 & 4 & & & & & \mathrm{G} & \mathrm{B} \\ \mathrm{N} & \mathrm{V} & \mathrm{S} & & 2 & 3 & 4 & 5 & 6 & 7 & & \mathrm{G} & \mathrm{B}\end{array}$

$\mathrm{N}$

3

$\mathrm{R}$

$\mathrm{R}$

\begin{tabular}{|c|c|c|c|c|c|c|c|c|c|c|c|}
\hline & & $\mathrm{S}$ & & & & & & 6 & & & B \\
\hline $\mathrm{N}$ & V & $\mathrm{S}$ & & & & & 5 & 6 & 7 & $\mathrm{G}$ & B \\
\hline \multirow[t]{2}{*}{$\mathrm{N}$} & & & & & & 4 & 5 & & & $\mathrm{G}$ & \\
\hline & & $\mathrm{S}$ & & & & & & 6 & & & B \\
\hline \multirow[t]{2}{*}{$\mathrm{N}$} & & $\mathrm{S}$ & & & & & & 6 & & & B \\
\hline & V & $S$ & & & & & 5 & 6 & 7 & & B \\
\hline \multirow[t]{2}{*}{$\mathrm{N}$} & $\mathrm{V}$ & $\mathrm{S}$ & 1 & 2 & 3 & 4 & 5 & 6 & & $\mathrm{G}$ & B \\
\hline & $\mathrm{V}$ & $S$ & & & & & 5 & & 7 & $\mathrm{G}$ & \\
\hline $\mathrm{N}$ & $\mathrm{V}$ & & & 2 & 3 & & 5 & & & $\mathrm{G}$ & B \\
\hline
\end{tabular}

$\begin{array}{lll}7 & 8 & \mathrm{G}\end{array}$

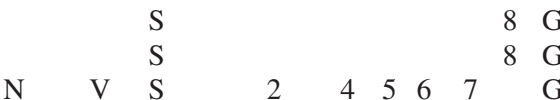

$\mathrm{S} \quad 8 \mathrm{G}$

$\mathrm{N} \quad 1 \quad \mathrm{R}$

$\begin{array}{llllll}\mathrm{N} & \mathrm{V} & 1 & 2 & 3 & \mathrm{G}\end{array}$

$8 \mathrm{G}$

S

$8 \mathrm{G}$

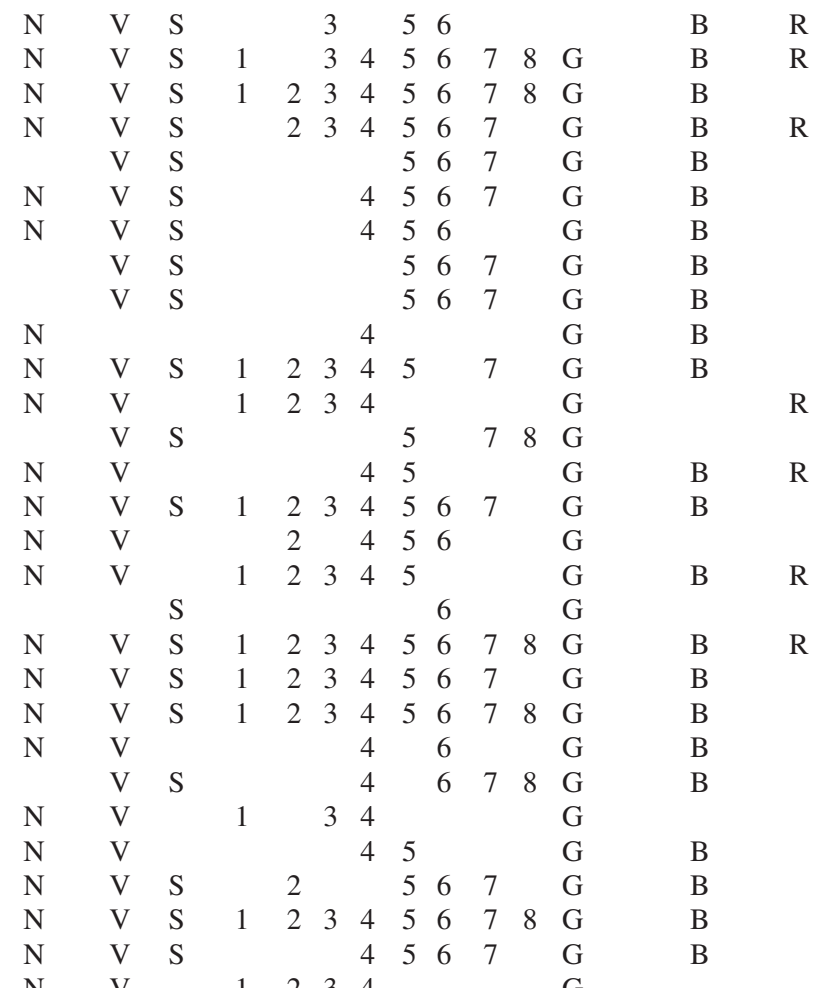


Species

Euchiton involucratus Euchiton sphaericus *Gamochaeta species

*Gazania species

*Hedypnois rhagadioloides

Helichrysum rutidolepis

*Helminthotheca echioides

*Hypochaeris glabra

*Hypochaeris radicata

Isoetopsis graminifolia

*Lactuca saligna

*Lactuca serriola

*Leontodon taraxacoides

Minuria cunninghamii

Myriocephalus rhizocephalus

Olearia pimeleoides

Picris squarrosa

Pogonolepis muelleriana

Polycalymma stuartii

Pseudognaphalium luteoalbum

Pycnosorus pleiocephalus

* Reichardia tingitana

Rhodanthe corymbiflora

Rhodanthe stuartiana

*Scorzonera laciniata

Senecio cunninghamii

Senecio glossanthus

*Senecio pterophorus

Senecio quadridentatus

Senecio runcinifolius

Senecio spanomerus

Solenogyne dominii

*Sonchus asper

Sonchus hydrophilus

*Sonchus oleraceus

*Taraxacum species

Triptilodiscus pygmaeus

*Urospermum picroides

Vittadinia cervicularis var. cervicularis

Vittadinia cuneata

var. cuneata

var. hirsuta

Vittadinia dissecta

Vittadinia gracilis

*Xanthium occidentale

*Xanthium orientale

*Xanthium spinosum

Xerochrysum bracteatum

\section{Boraginaceae}

*Amsinckia calycina

*Echium plantagineum

*Heliotropium curassavicum

Omphalolappula concava

Plagiobothrys elachanthus

\section{Brassicaceae}

*Alyssum linifolium

*Brassica tournefortii

* Capsella bursa-pastoris

* Carrichtera annua

*Lepidium africanum

*Lepidium bonariense

Pachymitus cardaminoides

* Rapistrum rugosum

Rorippa eustylis group

$$
\text { R. eustylis }
$$

R. laciniata

*Rorippa palustris

*Sisymbrium erysimoides
State

River section

Vegetation zone

$\begin{array}{llllllllllll}\text { NSW Vic SA } & 1 & 2 & 3 & 4 & 5 & 6 & 7 & 8 & \text { RedGm } & \text { BlkBx } & \text { Rises }\end{array}$

\begin{tabular}{|c|c|c|c|c|c|c|c|c|c|c|c|c|c|}
\hline & & S & & & & \multicolumn{8}{|c|}{$8 \mathrm{G}$} \\
\hline $\mathrm{N}$ & $\mathrm{V}$ & S & & 2 & 3 & 4 & 5 & 6 & 7 & & $\mathrm{G}$ & B & $\mathrm{R}$ \\
\hline $\mathrm{N}$ & $\mathrm{V}$ & & 1 & 2 & & & & & & & $\mathrm{G}$ & & \\
\hline & $\mathrm{V}$ & S & & & & & 5 & 6 & & & $\mathrm{G}$ & & \\
\hline $\mathrm{N}$ & V & & & & & 4 & 5 & & & & $\mathrm{G}$ & & $\mathrm{R}$ \\
\hline & $\mathrm{V}$ & & 1 & & & & & & & & $\mathrm{G}$ & & \\
\hline $\mathrm{N}$ & V & S & & & 3 & 4 & & & 7 & 8 & $\mathrm{G}$ & B & \\
\hline $\mathrm{N}$ & V & $\mathrm{S}$ & & 2 & 3 & 4 & 5 & 6 & 7 & & G & B & \\
\hline $\mathrm{N}$ & V & S & 1 & 2 & 3 & 4 & & 6 & 7 & 8 & $\mathrm{G}$ & B & \\
\hline $\mathrm{N}$ & V & S & & & & & 5 & 6 & & & & B & \\
\hline $\mathrm{N}$ & V & $\mathrm{S}$ & 1 & 2 & 3 & 4 & & & 7 & & $\mathrm{G}$ & B & \\
\hline $\mathrm{N}$ & $\mathrm{V}$ & S & 1 & 2 & 3 & 4 & 5 & 6 & 7 & & $\mathrm{G}$ & B & R \\
\hline $\mathrm{N}$ & V & & 1 & 2 & 3 & 4 & & & & & G & B & \\
\hline & & S & & & & & & 6 & & & & B & \\
\hline & V & & & & & & 5 & & & & & B & \\
\hline & & S & & & & & & 6 & & & & B & \\
\hline $\mathrm{N}$ & V & $\mathrm{S}$ & & & & 4 & 5 & 6 & 7 & 8 & $\mathrm{G}$ & B & \\
\hline $\mathrm{N}$ & V & S & & & & & 5 & 6 & & & G & B & \\
\hline & V & S & & & & & 5 & 6 & 7 & & G & B & $\mathrm{R}$ \\
\hline $\mathrm{N}$ & $\mathrm{V}$ & S & 1 & 2 & 3 & 4 & 5 & 6 & 7 & & $\mathrm{G}$ & B & \\
\hline & V & S & & & & & & 6 & & & & B & \\
\hline $\mathrm{N}$ & V & S & & & & & 5 & 6 & 7 & 8 & $\mathrm{G}$ & B & \\
\hline $\mathrm{N}$ & V & & & & & 4 & 5 & 6 & & & G & B & \\
\hline $\mathrm{N}$ & V & S & & & & & & 6 & & & & B & \\
\hline $\mathrm{N}$ & V & & & & & 4 & & & & & $\mathrm{G}$ & & \\
\hline $\mathrm{N}$ & V & S & & & & 4 & & 6 & & & G & & \\
\hline $\mathrm{N}$ & V & S & & & & 4 & 5 & 6 & 7 & & G & B & \\
\hline & & $\mathrm{S}$ & & & & & & & 7 & 8 & $\mathrm{G}$ & & \\
\hline $\mathrm{N}$ & V & S & 1 & 2 & 3 & 4 & 5 & 6 & & & G & B & $P$ \\
\hline $\mathrm{N}$ & V & S & & 2 & 3 & 4 & 5 & 6 & 7 & & $\mathrm{G}$ & B & \\
\hline $\mathrm{N}$ & V & S & & & & & 5 & 6 & 7 & 8 & G & B & \\
\hline $\mathrm{N}$ & $\mathrm{V}$ & & & 2 & 3 & & & & & & $\mathrm{G}$ & & $\mathrm{R}$ \\
\hline $\mathrm{N}$ & $\mathrm{V}$ & & 1 & 2 & 3 & 4 & 5 & 6 & & & $\mathrm{G}$ & B & $\mathrm{R}$ \\
\hline $\mathrm{N}$ & V & $\mathrm{S}$ & & & & 4 & 5 & 6 & 7 & 8 & $\mathrm{G}$ & B & \\
\hline $\mathrm{N}$ & V & $S$ & 1 & 2 & 3 & 4 & 5 & 6 & 7 & 8 & $\mathrm{G}$ & B & \\
\hline & & $S$ & & & & & & & 7 & 8 & $\mathrm{G}$ & & \\
\hline & V & & & 2 & & & & & & & $\mathrm{G}$ & & \\
\hline & $\mathrm{V}$ & $\mathrm{S}$ & & & & & 5 & 6 & 7 & 8 & $\mathrm{G}$ & B & \\
\hline $\mathrm{N}$ & V & $S$ & & & & 4 & 5 & 6 & & & $\mathrm{G}$ & B & \\
\hline $\mathrm{N}$ & $\mathrm{V}$ & $S$ & & & & 4 & 5 & 6 & 7 & 8 & $\mathrm{G}$ & B & \\
\hline
\end{tabular}

$\begin{array}{lllllllllllll}\mathrm{N} & \mathrm{V} & \mathrm{S} & & 4 & 5 & 6 & 7 & \mathrm{G} & \mathrm{B} & \mathrm{R} \\ \mathrm{N} & \mathrm{V} & & 2 & 4 & 5 & 6 & & & \mathrm{G} & \mathrm{B} & \\ & \mathrm{V} & & & & 5 & & & & \mathrm{G} & & \\ \mathrm{N} & & \mathrm{S} & & & & 6 & 7 & 8 & \mathrm{G} & \mathrm{B} & \\ \mathrm{N} & \mathrm{V} & \mathrm{S} & & 4 & 5 & & 7 & 8 & \mathrm{G} & & \\ \mathrm{N} & & & & 4 & 5 & 6 & & & \mathrm{G} & \mathrm{B}\end{array}$

$\mathrm{N}$

$\begin{array}{lllllllllllll}\mathrm{N} & \mathrm{V} & \mathrm{S} & 1 & 2 & 3 & 4 & 5 & 6 & \mathrm{G} & \mathrm{B} & \mathrm{R}\end{array}$

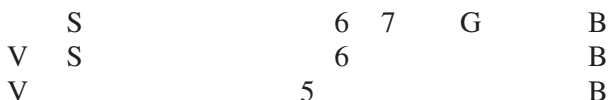

$\mathrm{R}$

R

$\mathrm{R}$

$\mathrm{R}$

$\mathrm{R}$

$\mathrm{R}$

V S

$6 \quad$ B

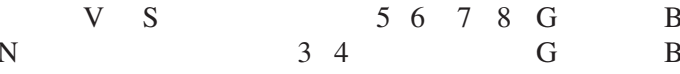

$\mathrm{R}$

R

西

$\mathrm{R}$

$\mathrm{R}$

(n)

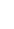

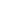

(2)
$\mathrm{V}$

$\begin{array}{lll} & & \mathrm{S} \\ \mathrm{N} & \mathrm{V} & \mathrm{S}\end{array}$

$\begin{array}{lllllllll} & 3 & 4 & 5 & 6 & 7 & 8 & G & \end{array}$ 
Species

* Sisymbrium irio

* Sisymbrium officinale

*Sisymbrium orientale

Callitrichaceae

Callitriche sonderi

*Callitriche stagnalis

Campanulaceae

Wahlenbergia communis

Wahlenbergia fluminalis

Wahlenbergia gracilienta

Wahlenbergia gracilis

Wahlenbergia graniticola

Wahlenbergia luteola

Wahlenbergia multicaulis

Wahlenbergia tumidifructa

Caryophyllaceae

*Cerastium glomeratum

* Petrorhagia velutina

Scleranthus minusculus

* Silene species

* Spergularia diandra

* Spergularia rubra

Stellaria angustifolia

* Stellaria media

Casuarinaceae

Allocasuarina luehmannii

Chenopodiaceae

Atriplex eardleyae

Atriplex conduplicata

Atriplex leptocarpa

Atriplex limbata

Atriplex lindleyi

Atriplex nummularia

Atriplex pseudocampanulata

Atriplex rhagodioides

Atriplex semibaccata group

A. semibaccata

A. suberecta

Atriplex spongiosa

Atriplex stipitata

Atriplex vesicaria

*Chenopodium album

Chenopodium glaucum

*Chenopodium murale

Chenopodium nitrariaceum

Dissocarpus biflorus

Dysphania glomulifera

Einadia nutans

Enchylaena tomentosa

Maireana appressa

Maireana brevifolia

Maireana enchylaenoides

Maireana pentagona

Maireana pentatropis

Maireana pyramidata

Malacocera tricornis

Osteocarpum species

O. acropterum

O. salsuginosum

Rhagodia spinescens

Salsola kali

Sclerolaena brachyptera

Sclerolaena diacantha

Sclerolaena muricata var. muricata

Sclerolaena muricata var. villosa

Sclerolaena obliquicuspis

Sclerolaena patenticuspis

Sclerolaena stelligera
State

River section

Vegetation zone

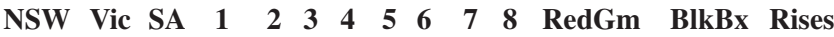

\begin{tabular}{|c|c|c|c|c|c|c|c|c|c|c|c|c|c|}
\hline $\mathrm{N}$ & $\mathrm{V}$ & $S$ & & & 3 & 4 & & 6 & & & $\mathrm{G}$ & B & \\
\hline $\mathrm{N}$ & & & & & 3 & & & & & & $\mathrm{G}$ & & \\
\hline $\mathrm{N}$ & $\mathrm{V}$ & & & & & 4 & & 6 & & & $\mathrm{G}$ & B & \\
\hline $\mathrm{N}$ & & & & & & 4 & & & & & $\mathrm{G}$ & & \\
\hline $\mathrm{N}$ & & $\mathrm{S}$ & & & & 4 & & 6 & & 8 & $\mathrm{G}$ & & \\
\hline $\mathrm{N}$ & $\mathrm{V}$ & & & 2 & 3 & 4 & & & & & $\mathrm{G}$ & B & $\mathrm{R}$ \\
\hline $\mathrm{N}$ & $\mathrm{V}$ & $\mathrm{S}$ & 1 & 2 & 3 & 4 & 5 & 6 & 7 & & $\mathrm{G}$ & B & $\mathrm{R}$ \\
\hline $\mathrm{N}$ & $\mathrm{V}$ & $\mathrm{S}$ & & & & & 5 & 6 & & & & B & $\mathrm{R}$ \\
\hline $\mathrm{N}$ & $\mathrm{V}$ & & 1 & & 3 & 4 & & & & & $\mathrm{G}$ & & \\
\hline $\mathrm{N}$ & & & 1 & & 3 & & & & & & & & $\mathrm{R}$ \\
\hline $\mathrm{N}$ & & & 1 & & & & & & & & & & $\mathrm{R}$ \\
\hline $\mathrm{N}$ & $\mathrm{V}$ & & & & 3 & & & & & & $\mathrm{G}$ & & \\
\hline $\mathrm{N}$ & V & $\mathrm{S}$ & & & & & 5 & 6 & & & $\mathrm{G}$ & B & $\mathrm{R}$ \\
\hline $\mathrm{N}$ & $\mathrm{V}$ & $\mathrm{S}$ & 1 & 2 & 3 & 4 & & & & 8 & $\mathrm{G}$ & & \\
\hline \multirow[t]{4}{*}{$\mathrm{N}$} & V & & 1 & 2 & 3 & 4 & & & & & $\mathrm{G}$ & B & $\mathrm{R}$ \\
\hline & V & & & & & & 5 & & & & & & $\mathrm{R}$ \\
\hline & V & $\mathrm{S}$ & & & & 4 & 5 & 6 & 7 & 8 & $\mathrm{G}$ & B & $\mathrm{R}$ \\
\hline & & $\mathrm{S}$ & & & & & & 6 & & & $\mathrm{G}$ & B & \\
\hline $\mathrm{N}$ & V & $\mathrm{S}$ & & 2 & 3 & 4 & 5 & 6 & 7 & 8 & $\mathrm{G}$ & B & \\
\hline $\mathrm{N}$ & V & & & 2 & 3 & 4 & & & & & $\mathrm{G}$ & B & \\
\hline $\mathrm{N}$ & & & & 2 & & 4 & & & & & $\mathrm{G}$ & & \\
\hline
\end{tabular}

$\mathrm{N}$

4

B

$\begin{array}{ccc} & \text { V } & \text { S } \\ & \text { V } & \\ N & \text { V } & \text { S } \\ & & \text { S } \\ \text { N } & \text { V } & \text { S } \\ \text { N } & \text { V } & \text { S } \\ & \text { V } & \\ & \text { V } & \text { S } \\ \text { N } & \text { V } & \text { S }\end{array}$

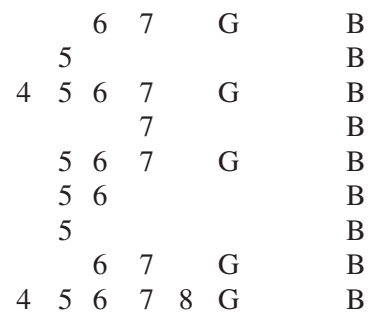

V

$\mathrm{N} \quad \mathrm{V} \quad \mathrm{S}$

6

$6 \quad \mathrm{~B}$

$78 \mathrm{G}$

35

456

56

5

$\begin{array}{lllllll}3 & 4 & 5 & 6 & 7 & 8 & G\end{array}$

$\begin{array}{llllll}4 & 5 & 6 & 7 & 8 & \mathrm{G}\end{array}$

$\begin{array}{ll}6 & \\ 6 & 7\end{array}$

34

$56-B$

$\mathrm{R}$

N $\quad \mathrm{V}$

567

6

56

$\begin{array}{lll}5 & 6 & 7\end{array}$

$\mathrm{R}$

$\mathrm{R}$

$\mathrm{R}$

$\begin{array}{lllllll}4 & 5 & 6 & & \mathrm{G} & \mathrm{B} \\ 4 & & 6 & 7 & \mathrm{G} & \mathrm{B} \\ & 5 & 6 & 7 & \mathrm{G} & \mathrm{B} \\ & & 6 & & & \mathrm{~B} \\ 4 & 5 & 6 & 7 & \mathrm{G} & \mathrm{B} \\ 4 & 5 & & 7 & \mathrm{G} & \mathrm{B} \\ & & 6 & 7 & \mathrm{G} & \mathrm{B} \\ & & 6 & & & \mathrm{~B} \\ 4 & 5 & 6 & 7 & & \mathrm{~B}\end{array}$


Species

Sclerolaena tricuspis Suaeda australis

Tecticornia indica

Tecticornia pergranulata

Tecticornia triandra

\section{Clusiaceae}

Hypericum gramineum

*Hypericum perforatum

Convolvulaceae

Calystegia sepium

Convolvulus erubescens

Cressa australis

Dichondra repens

Crassulaceae

Crassula colorata

Crassula decumbens

Crassula helmsii

Crassula peduncularis

Crassula sieberiana

Cucurbitaceae

*Citrullus lanatus

Cuscutaceae

*Cuscuta species

Euphorbiaceae

Chamaesyce drummondii

* Euphorbia peplus

* Euphorbia terracina

Phyllanthus lacunarius

Fabaceae

Acacia acinacea

Acacia dealbata

Acacia ligulata

Acacia salicina

*Acacia saligna

Acacia stenophylla

Cullen australasicum

Cullen pallidum

Glycine clandestina

Glycine tabacina

Glycyrrhiza acanthocarpa

*Lathyrus angulatus

Lotus cruentus

*Medicago minima

* Medicago polymorpha

*Medicago truncatula

*Melilotus albus

* Melilotus indicus

Swainsona greyana

Swainsona microphylla

Swainsona phacoides

*Trifolium angustifolium

*Trifolium arvense

*Trifolium campestre

*Trifolium cernuum

*Trifolium dubium

*Trifolium glomeratum

*Trifolium ornithopodioides

*Trifolium repens

*Trifolium striatum

*Trifolium subterraneum

*Trifolium tomentosum

*Vicia hirsuta

*Vicia monantha

*Vicia sativa

ssp. nigra

ssp. sativa

*Vicia tetrasperma
State

River section

Vegetation zone

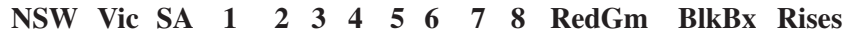

$\begin{array}{llllllllll}\mathrm{N} & \mathrm{V} & \mathrm{S} & 4 & 5 & 6 & 7 & & \\ & & \mathrm{~S} & & & 6 & 7 & & \mathrm{~B} \\ & & \mathrm{~S} & & & 6 & 7 & \mathrm{G} & \mathrm{B} \\ & \mathrm{V} & \mathrm{S} & & 5 & 6 & 7 & \mathrm{G} & \mathrm{B} \\ \mathrm{N} & \mathrm{V} & \mathrm{S} & & 5 & 6 & 7 & & \mathrm{~B}\end{array}$

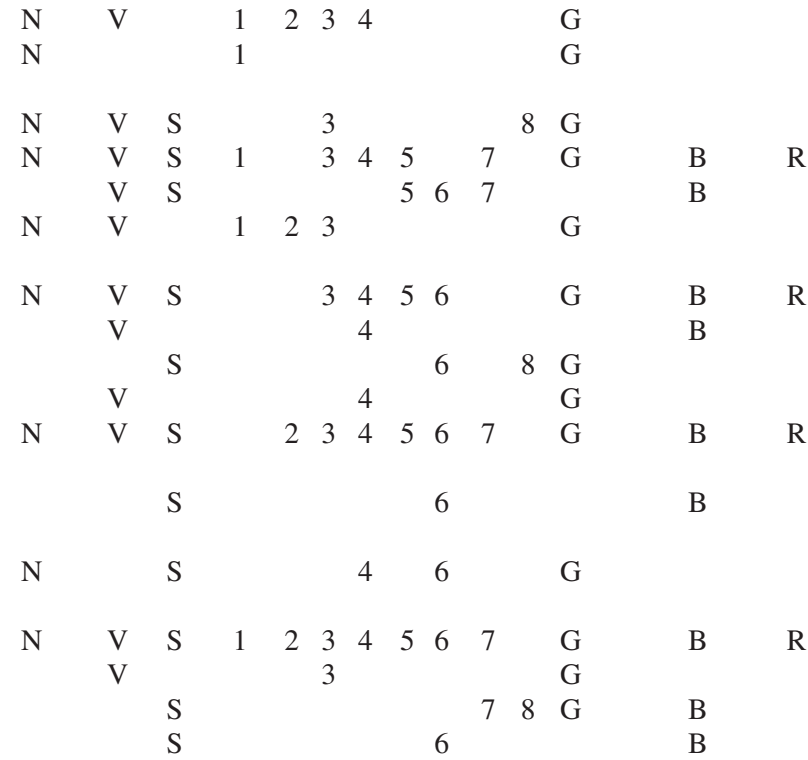

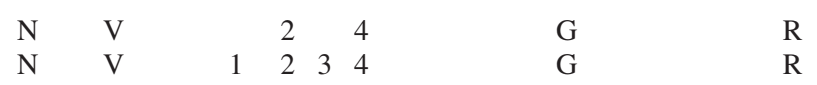

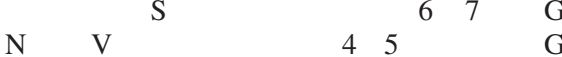

$\mathrm{S} \quad 8 \mathrm{G}$

$\begin{array}{lllllllll}\mathrm{N} & \mathrm{V} & \mathrm{S} & 4 & 5 & 6 & 7 & \mathrm{G}\end{array}$

B

$\mathrm{R}$

$\mathrm{R}$

B

$\mathrm{R}$

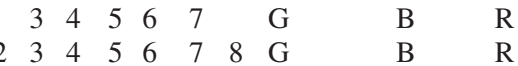

$\begin{array}{lll}7 & 8 & \mathrm{G}\end{array}$

$8 \mathrm{G}$

$\begin{array}{llll}6 & 7 & 8 & \mathrm{G}\end{array}$

$7 \quad \mathrm{G}$

$S$

V S

$\mathrm{V} \quad \mathrm{S}-5$

$\begin{array}{llllll}\mathrm{N} & \mathrm{V} & 1 & 2 & 3 & 4\end{array}$

$\begin{array}{llllll}\mathrm{N} & \mathrm{V} & 1 & 2 & 3 & 4\end{array}$

$\begin{array}{llll}1 & 2 & 3 & 4\end{array}$

$\begin{array}{llll}1 & 2 & 3 & 4\end{array}$

$\begin{array}{llll}1 & 2 & 3 & 4\end{array}$

$\begin{array}{llll}1 & 2 & 3 & 4\end{array}$

$\begin{array}{lllll}\mathrm{S} & 1 & 2 & 3 & 4 \\ & 1 & & \end{array}$

$\begin{array}{lllll}\mathrm{S} & 1 & 2 & 3 & 4\end{array}$

$\begin{array}{llll}1 & 2 & 3 & 4\end{array}$

$\begin{array}{llll}1 & 2 & 3 & 4\end{array}$

$\begin{array}{llll}1 & 2 & 3 & 4\end{array}$

134

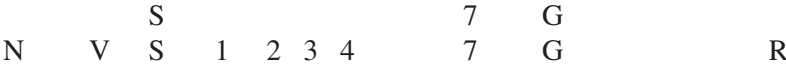

$7 \quad \mathrm{G}$

G

G

G

$\mathrm{G}$

G

$\mathrm{G}$

$8 \mathrm{G}$

G

$\mathrm{G}$

G

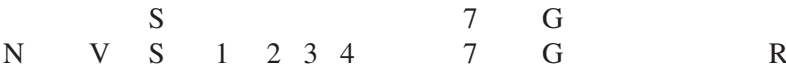

$\mathrm{N}$

3

$\mathrm{G}$ 
Species

Frankeniaceae

Frankenia serpyllifolia

Fumariaceae

*Fumaria bastardii

*Fumaria capreolata

*Fumaria densiflora

*Fumaria muralis

Gentianaceae

*Centaurium erythraea

*Centaurium tenuiflorum

Schenkia spicata

Geraniaceae

*Erodium cicutarium

Erodium crinitum

Geranium retrorsum

Geranium solanderi

Goodeniaceae

Goodenia fascicularis

Goodenia glauca

Goodenia gracilis

Goodenia heteromera

Goodenia pusilliflora

Haloragaceae

Haloragis aspera

* Myriophyllum aquaticum

Myriophyllum crispatum group M. crispatum

$M$. verrucosum

\section{Lamiaceae}

Ajuga australis

*Lamium amplexicaule

Lycopus australis

* Marrubium vulgare

Mentha australis

Mentha diemenica

*Mentha pulegium

* Mentha x spicata

Teucrium racemosum

Linaceae

Linum marginale

Lobeliaceae

Isotoma fluviatilis ssp. australis

Isotoma tridens

Lobelia pratioides

Pratia concolor

Loranthaceae

Amyema miquelii

Lythraceae

Lythrum hyssopifolia

Malvaceae

Malva preissiana

Sida corrugata var. angustifolia

Sida corrugata var. corrugata

Sida trichopoda

Menyanthaceae

Nymphoides crenata

Myoporaceae

Eremophila divaricata

Myoporum montanum

Myrsinaceae

*Anagallis arvensis

Myrtaceae

Callistemon brachyandrus

Calytrix tetragona

Eucalyptus camaldulensis

Eucalyptus largiflorens

Eucalyptus melliodora

Eucalyptus microcarpa
State

River section

Vegetation zone

$\begin{array}{lllllllllllll}\text { NSW Vic SA } & 1 & 2 & 3 & 4 & 5 & 6 & 7 & 8 & \text { RedGm } & \text { BlkBx } & \text { Rises }\end{array}$

$\mathrm{N}$

56

B

$\mathrm{N}$

$\begin{array}{ll} & \text { S } \\ \mathrm{V} & \end{array}$ 5
$4 \quad$ G

B

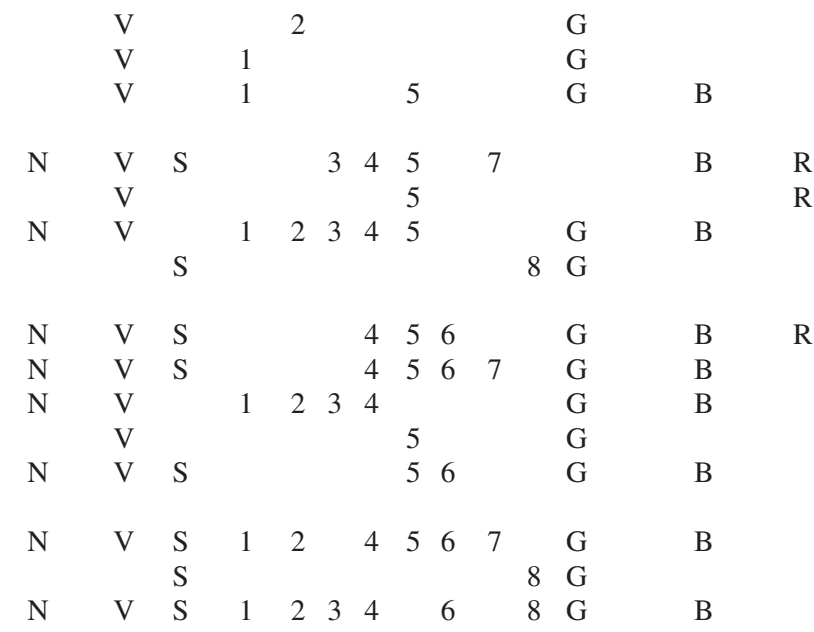

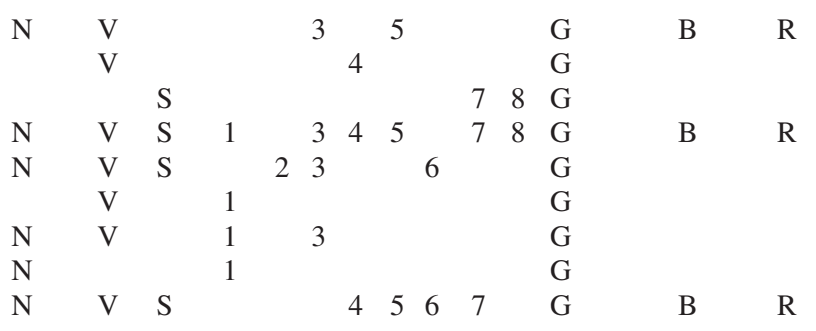

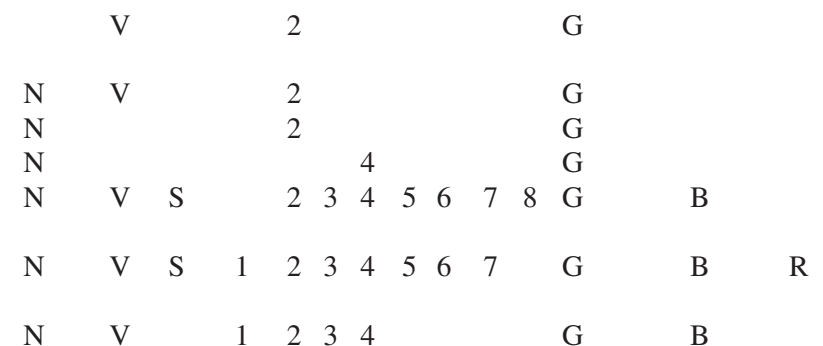

$\begin{array}{llllllll}\mathrm{N} & \mathrm{V} & 1 & 2 & 3 & 4 & \mathrm{G} & \mathrm{B}\end{array}$

$\begin{array}{llllllllllll} & & \mathrm{S} & & & & & 7 & & \mathrm{~B} & \\ \mathrm{~N} & \mathrm{~V} & & & 3 & 4 & 5 & 6 & & \mathrm{G} & \mathrm{B} & \mathrm{R} \\ \mathrm{N} & \mathrm{V} & & 3 & 4 & & & & & \mathrm{~B} & \mathrm{R} \\ \mathrm{N} & \mathrm{V} & & 1 & & 4 & 5 & & & \mathrm{G} & \mathrm{B} & \end{array}$

$\begin{array}{lllll}\mathrm{N} & \mathrm{V} & 3 & 4 & \mathrm{G}\end{array}$

$\begin{array}{llllllllll}\mathrm{N} & \mathrm{V} & \mathrm{S} & 5 & 6 & 7 & & & & \mathrm{~B} \\ & & \mathrm{~S} & & & 7 & 8 & \mathrm{G} & \end{array}$

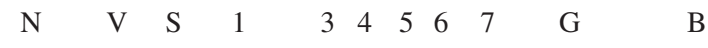

$\begin{array}{lllllllllllllll} & & \mathrm{S} & & & & & & & 7 & \mathrm{G} & & \\ \mathrm{N} & & & & & 3 & & & & & & & \mathrm{R} \\ \mathrm{N} & \mathrm{V} & \mathrm{S} & 1 & 2 & 3 & 4 & 5 & 6 & 7 & 8 & \mathrm{G} & \mathrm{B} & \mathrm{R} \\ & & \mathrm{S} & & & & 4 & 5 & 6 & 7 & & \mathrm{G} & \mathrm{B} & \mathrm{R} \\ \mathrm{N} & \mathrm{V} & & 1 & & 3 & & & & & \mathrm{G} & & \mathrm{R} \\ & \mathrm{V} & & & 2 & & 4 & & & & & \mathrm{G} & & \mathrm{R}\end{array}$ 
Species

Melaleuca lanceolata

Oleaceae

*Fraxinus rotundifolia

Onagraceae

Epilobium billardierianum

Epilobium hirtigerum

*Ludwigia peploides

Oxalidaceae

Oxalis perennans

* Oxalis pes-caprae

Oxalis radicosa

Pittosporaceae

Pittosporum angustifolium

Plantaginaceae

Plantago cunninghamii group

P. cunninghamii

P. drummondii

P. turrifera

Plantago debilis

*Plantago lanceolata

Polygonaceae

*Acetosella vulgaris

Muehlenbeckia florulenta

Muehlenbeckia horrida ssp. horrida

Persicaria decipiens

Persicaria hydropiper

Persicaria lapathifolia

Persicaria prostrata

*Polygonum aviculare

Polygonum plebeium

Rumex bidens

Rumex brownii

*Rumex crispus

Rumex crystallinus

*Rumex pulcher

Portulacaceae

Calandrinia calyptrata

Calandrinia eremaea

Calandrinia volubilis

Proteaceae

Hakea leucoptera

Hakea tephrosperma

Ranunculaceae

Myosurus australis

Ranunculus amphitrichus

Ranunculus inundatus

Ranunculus lappaceus

*Ranunculus muricatus

Ranunculus pentandrus

Ranunculus pumilio var. politus

Ranunculus pumilio var. pumilio

*Ranunculus sceleratus

Ranunculus sessiliflorus

*Ranunculus trilobus

\section{Rosaceae}

Acaena novae-zelandiae

*Rosa rubiginosa

*Rubus fruticosus spp. agg.

Rubiaceae

Asperula conferta

Asperula gemella

* Galium aparine

Salicaceae

*Salix babylonica

*Salix x rubens

Santalaceae

Exocarpos strictus
State River section Vegetation zone

$\begin{array}{lllllllllllll}\text { NSW Vic SA } & 1 & 2 & 3 & 4 & 5 & 6 & 7 & 8 & \text { RedGm } & \text { BlkBx } & \text { Rises }\end{array}$

$\mathrm{N} \quad \mathrm{S}$

46

B

S

$8 \mathrm{G}$

$\begin{array}{lllllllllllll}\mathrm{N} & \mathrm{V} & & 1 & & 3 & 4 & & & \mathrm{G} & \mathrm{B} & \\ \mathrm{N} & \mathrm{V} & & 1 & 2 & 3 & 4 & & & \mathrm{G} & & \\ \mathrm{N} & \mathrm{V} & \mathrm{S} & 1 & 2 & 3 & 4 & & 6 & & \mathrm{G} & & \\ & & & & & & & & & & & & \\ \mathrm{N} & \mathrm{V} & \mathrm{S} & 1 & 2 & 3 & 4 & 5 & 6 & & \mathrm{G} & \mathrm{B} & \mathrm{R} \\ & & \mathrm{S} & & & & & & & 8 & \mathrm{G} & & \\ \mathrm{N} & & & & & 3 & & & & & & & \mathrm{R}\end{array}$

V

4

G

$\mathrm{N} \quad \mathrm{V} \quad \mathrm{S}$

$\begin{array}{llll}5 & 6 & 7 & \mathrm{G}\end{array}$

B

$\begin{array}{lllll}\mathrm{N} & \mathrm{V} & & 4 & \mathrm{G} \\ \mathrm{N} & \mathrm{V} & 1 & 4 & \mathrm{G}\end{array}$

$\begin{array}{llllll}\mathrm{N} & \mathrm{V} & 1 & \mathrm{G}\end{array}$

$\begin{array}{llllllllll}\mathrm{N} & \mathrm{V} & \mathrm{S} & 4 & 5 & 6 & 7 & 8 & \mathrm{G} & \mathrm{B}\end{array}$

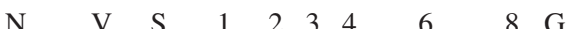

$\begin{array}{lllllllll}\mathrm{N} & \mathrm{V} & 1 & 2 & 3 & \mathrm{G} & \end{array}$

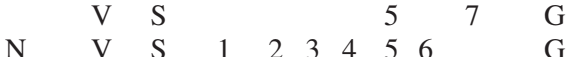

$\begin{array}{lllllllllll}\mathrm{N} & \mathrm{V} & \mathrm{S} & 1 & 2 & 3 & 4 & 5 & 6 & \mathrm{G}\end{array}$

$\begin{array}{llllllllll}\mathrm{N} & \mathrm{V} & \mathrm{S} & & 2 & & 4 & 5 & 7 & \mathrm{G}\end{array}$

$\begin{array}{lllll}S & 6 & G\end{array}$

$\begin{array}{llllllllllllll}\mathrm{N} & \mathrm{V} & \mathrm{S} & 1 & 2 & 3 & 4 & 5 & 6 & 7 & \mathrm{G} & & \mathrm{B} & \mathrm{R}\end{array}$

$\begin{array}{llllllll}\mathrm{N} & \mathrm{V} & \mathrm{S} & 1 & 2 & 7 & 8 & \mathrm{G}\end{array}$

$\begin{array}{lllllllll}\mathrm{N} & \mathrm{V} & 1 & 2 & 3 & 4 & \mathrm{G} & \mathrm{B}\end{array}$

$\mathrm{N}-1$

$\begin{array}{lllllllllll}N & \text { V } & & 4 & 5 & & & & \text { B } & \\ N & \text { V } & \text { S } & & 5 & 6 & 7 & \text { G } & \text { B } & \text { R } \\ \text { N } & \text { V } & \text { S } & & 5 & 6 & & & \text { B } & \end{array}$

$\mathrm{N} \quad 4^{5} \quad$ B

$\begin{array}{llllllllllllll} & \mathrm{V} & \mathrm{S} & & & & 4 & 5 & 6 & & & \mathrm{G} & \mathrm{B} \\ & & \mathrm{S} & & & & & & & & 8 & \mathrm{G} & \\ \mathrm{N} & \mathrm{V} & & 1 & 2 & 3 & 4 & & & & & \mathrm{G} & \\ \mathrm{N} & \mathrm{V} & & & 2 & 3 & 4 & & & & & \mathrm{G} & \\ \mathrm{N} & \mathrm{V} & \mathrm{S} & 1 & 2 & 3 & 4 & & & & 8 & \mathrm{G} & \\ & \mathrm{V} & \mathrm{S} & & & & & 5 & 6 & 7 & & \mathrm{G} & \mathrm{B} \\ & \mathrm{V} & & 1 & 2 & & & & & & & \mathrm{G} & \\ \mathrm{N} & \mathrm{V} & & 1 & & 3 & 4 & & & & & \mathrm{G} & \mathrm{B} \\ \mathrm{N} & \mathrm{V} & & & 2 & & 4 & & & & \mathrm{G} & \mathrm{B} \\ \mathrm{N} & & & & & & 4 & & & & & \mathrm{G} & \end{array}$

$\begin{array}{lllllll} & \mathrm{V} & & & 3 & & \mathrm{G} \\ \mathrm{N} & \mathrm{V} & 1 & 2 & 3 & 4 & \mathrm{G} \\ \mathrm{V} & & 2 & 3 & & \mathrm{G}\end{array}$

$\begin{array}{lllll}\mathrm{N} & \mathrm{V} & 5 & \mathrm{G} & \mathrm{B}\end{array}$

$\begin{array}{llllllllll}\mathrm{N} & \mathrm{V} & \mathrm{S} & 4 & 5 & 6 & 7 & 8 & \mathrm{G} & \mathrm{B}\end{array}$

$\begin{array}{lllllllll}\mathrm{N} & \mathrm{V} & 1 & 2 & 3 & 4 & 5 & \mathrm{G} & \mathrm{B}\end{array}$

$\begin{array}{lllllllll}\mathrm{N} & \mathrm{V} & \mathrm{S} & 1 & & 4 & 6 & 8 & \mathrm{G} \\ \mathrm{N} & \mathrm{V} & & 1 & 3 & & & & \mathrm{G}\end{array}$

$\begin{array}{llllll}\mathrm{N} & \mathrm{V} & 3 & 4 & \mathrm{G} & \mathrm{B}\end{array}$ 
Species

Sapindaceae

Dodonaea viscosa ssp. angustissima

Scrophulariaceae

Gratiola peruviana

*Kickxia spuria

Mimulus gracilis

Mimulus repens

* Orobanche minor

Stemodia florulenta

*Verbascum virgatum

*Veronica peregrina

Solanaceae

*Lycium ferocissimum

*Nicotiana glauca

Nicotiana velutina

Solanum esuriale

*Solanum nigrum

*Solanum pseudocapsicum

Urticaceae

*Urtica urens

Verbenaceae

* Phyla canescens

*Verbena bonariensis

*Verbena officinalis

*Verbena supina

Violaceae

Viola betonicifolia ssp. betonicifolia

Zygophyllaceae

Zygophyllum ammophilum

Zygophyllum aurantiacum

Zygophyllum confluens

Zygophyllum glaucum

Zygophyllum iodocarpum

\section{MONOCOTYLEDONS}

Alismataceae

*Alisma lanceolatum

Damasonium minus

Anthericaceae

Arthropodium minus

Dichopogon fimbriatus

Tricoryne elatior

Arecaceae

*Phoenix species

Asparagaceae

*Asparagus officinalis

Asphodelaceae

*Asphodelus fistulosus

Bulbine semibarbata

Cyperaceae

Bolboschoenus medianus

Carex appressa

Carex chlorantha

Carex gaudichaudiana

Carex inversa

Carex tereticaulis

*Cyperus eragrostis

Cyperus exaltatus

Cyperus gunnii

Cyperus gymnocaulos

Eleocharis acuta

Eleocharis pusilla

Fimbristylis aestivalis

Isolepis cernua

Isolepis inundata

* Isolepis marginata

Isolepis victoriensis

Schoenoplectus validus
State

River section

Vegetation zone

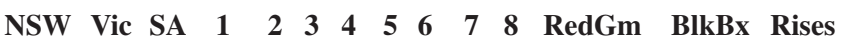

\begin{tabular}{|c|c|c|c|c|c|c|c|c|c|c|c|c|}
\hline & V & $\mathrm{S}$ & & & & & 5 & & 7 & & $\mathrm{G}$ & B \\
\hline \multirow[t]{2}{*}{$\mathrm{N}$} & V & $\mathrm{S}$ & & 2 & & & & & & 8 & $\mathrm{G}$ & \\
\hline & V & & 1 & & & & & & & & $\mathrm{G}$ & \\
\hline \multirow[t]{2}{*}{$\mathrm{N}$} & & & & & & 4 & & & & & & B \\
\hline & & $S$ & & & & & & 6 & 7 & & & B \\
\hline $\mathrm{N}$ & & & 1 & & & & & & & & & \\
\hline $\mathrm{N}$ & V & $\mathrm{S}$ & & & & & 5 & 6 & 7 & 8 & $\mathrm{G}$ & B \\
\hline $\mathrm{N}$ & & $\mathrm{S}$ & & 2 & 3 & & & & & 8 & $\mathrm{G}$ & \\
\hline \multirow[t]{4}{*}{$\mathrm{N}$} & V & $S$ & 1 & 2 & 3 & 4 & & 6 & & & $\mathrm{G}$ & B \\
\hline & $\mathrm{V}$ & $S$ & & & & 4 & & 6 & 7 & 8 & $\mathrm{G}$ & B \\
\hline & & $S$ & & & & & & & 7 & & $\mathrm{G}$ & \\
\hline & V & $\mathrm{S}$ & & & & & 5 & 6 & & & & B \\
\hline $\mathrm{N}$ & V & $\mathrm{S}$ & & & & 4 & 5 & 6 & 7 & & $\mathrm{G}$ & B \\
\hline $\mathrm{N}$ & V & $\mathrm{S}$ & & 2 & 3 & 4 & 5 & 6 & 7 & 8 & $\mathrm{G}$ & B \\
\hline $\mathrm{N}$ & & & & 2 & & & & & & & $\mathrm{G}$ & \\
\hline $\mathrm{N}$ & & $\mathrm{S}$ & & & 3 & 4 & & 6 & & 8 & $\mathrm{G}$ & B \\
\hline $\mathrm{N}$ & $\mathrm{V}$ & $\mathrm{S}$ & & & & 4 & 5 & 6 & 7 & 8 & $\mathrm{G}$ & B \\
\hline \multirow[t]{2}{*}{$\mathrm{N}$} & $\mathrm{V}$ & & 1 & & 3 & & & & & & $\mathrm{G}$ & \\
\hline & V & & & 2 & & & 5 & & & & $\mathrm{G}$ & \\
\hline $\mathrm{N}$ & $\mathrm{V}$ & & & & & & 5 & 6 & & & $\mathrm{G}$ & \\
\hline \multirow[t]{4}{*}{$\mathrm{N}$} & $\mathrm{V}$ & & 1 & & 3 & & & & & & $\mathrm{G}$ & \\
\hline & & $S$ & & & & & & 6 & & & & B \\
\hline & & $\mathrm{S}$ & & & & & & & 7 & & $\mathrm{G}$ & \\
\hline & & $\mathrm{S}$ & & & & & & 6 & & & & B \\
\hline \multirow[t]{2}{*}{$\mathrm{N}$} & V & & & & & & 5 & 6 & & & & B \\
\hline & $\mathrm{V}$ & & & & & & & 6 & & & & B \\
\hline
\end{tabular}

R

R

\begin{tabular}{|c|c|c|c|c|c|c|}
\hline \multicolumn{4}{|c|}{$\mathrm{S}$} & \multicolumn{3}{|c|}{$\mathrm{G}$} \\
\hline $\mathrm{N}$ & $\mathrm{V}$ & & & 4 & $\mathrm{G}$ & B \\
\hline $\mathrm{N}$ & $\mathrm{V}$ & & 2 & 4 & $\mathrm{G}$ & \\
\hline & $\mathrm{V}$ & & 2 & & $\mathrm{G}$ & \\
\hline $\mathrm{N}$ & $\mathrm{V}$ & 1 & 2 & & $\mathrm{G}$ & \\
\hline
\end{tabular}

N 1

$\begin{array}{llllllllll}\mathrm{N} & \mathrm{V} & \mathrm{S} & 1 & 4 & 5 & 6 & \mathrm{G} & \mathrm{B}\end{array}$

$\begin{array}{lllllllllll} & & \mathrm{S} & 2 & & 5 & 6 & 7 & 8 & \mathrm{G} & \mathrm{B} \\ \mathrm{N} & \mathrm{V} & \mathrm{S} & & 4 & 5 & 6 & 7 & & \mathrm{G} & \mathrm{B}\end{array}$

$\begin{array}{rrrrrrr} & \mathrm{S} & & 6 & 7 & & \mathrm{G} \\ \mathrm{V} & \mathrm{S} & 1 & & & 8 & \mathrm{G}\end{array}$

$\begin{array}{lllll}\mathrm{N} & & 1 & & \mathrm{G} \\ \mathrm{N} & \mathrm{V} & 1 & 3 & \mathrm{G}\end{array}$

$\begin{array}{lllllllll}\mathrm{N} & \mathrm{V} & 1 & & 3 & & \mathrm{G} & & \\ \mathrm{N} & \mathrm{V} & 1 & 2 & 3 & 4 & \mathrm{G} & \mathrm{B} & \mathrm{R}\end{array}$

$\begin{array}{llllllllll}\mathrm{N} & \mathrm{V} & 1 & 2 & 3 & 4 & \mathrm{~B} & \mathrm{~B} & \mathrm{R}\end{array}$

$\begin{array}{llllllll}\mathrm{N} & \mathrm{V} & 1 & 2 & 3 & 4 & \mathrm{G}\end{array}$

$\begin{array}{llllllllllll}\mathrm{N} & \mathrm{V} & \mathrm{S} & 1 & 2 & 3 & 4 & 5 & 6 & 7 & \mathrm{G}\end{array}$

$\mathrm{N} \quad 4 \quad \mathrm{~S} \quad \mathrm{G}$

$\begin{array}{lllllllll}\mathrm{N} & \mathrm{V} & \mathrm{S} & 4 & 5 & 6 & 7 & 8 & \mathrm{G}\end{array}$

$\begin{array}{llllllllllll}\mathrm{N} & \mathrm{V} & \mathrm{S} & 1 & 2 & 3 & 4 & 5 & 6 & 8 & \mathrm{G}\end{array}$

$\begin{array}{llllllll}\mathrm{N} & \mathrm{V} & 1 & 2 & 3 & 4 & \mathrm{G}\end{array}$

$\begin{array}{llll}\mathrm{N} & 2 & \mathrm{G} \\ \mathrm{S} & & 8 \mathrm{G}\end{array}$

\begin{tabular}{|c|c|}
\hline$S$ & 8 \\
\hline $\mathrm{S}$ & 8 \\
\hline
\end{tabular}

$\begin{array}{llllll}\mathrm{N} & & & & & \\ \mathrm{S} & & 7 & 8 & \mathrm{G}\end{array}$

$\mathrm{R}$ 
Species

Schoenus apogon

\section{Hydrocharitaceae}

Vallisneria australis

\section{Iridaceae}

*Romulea rosea

Juncaceae

Juncus amabilis

Juncus aridicola

*Juncus articulatus

Juncus bufonius

Juncus flavidus

Juncus holoschoenus

Juncus ingens

Juncus usitatus

Juncus vaginatus

Juncaginaceae

Triglochin centrocarpa

Triglochin procera

Triglochin striata

Lomandraceae

Lomandra collina

Lomandra multiflora ssp. multiflora

Orchidaceae

Microtis unifolia

Phormiaceae

Dianella longifolia

Poaceae

*Agrostis capillaris

Amphibromus fluitans

Amphibromus nervosus

Aristida jerichoensis

Austrodanthonia caespitosa

Austrodanthonia duttoniana

Austrodanthonia setacea

Austrostipa species

A. drummondii

A. nitida

A. nodosa

A. scabra ssp. falcata

*Avena barbata

*Avena fatua

*Avena sativa

* Briza maxima

* Briza minor

*Bromus alopecuros

Bromus arenarius

*Bromus catharticus

*Bromus diandrus

*Bromus hordeaceus

*Bromus madritensis

*Bromus rubens

Chloris truncata

*Cynodon dactylon

*Cynosurus echinatus

Deyeuxia quadriseta

Dichelachne micrantha

Echinochloa colona

*Echinochloa crus-galli

* Ehrharta erecta

* Ehrharta longiflora

*Elymus repens

Elymus scaber

Enneapogon avenaceus

Enteropogon acicularis

Eragrostis australasica

Eragrostis brownii

Eragrostis dielsii

Eragrostis elongata

State River section Vegetation zone

$\begin{array}{lllllllllllll}\text { NSW } & \text { Vic } & \text { SA } & 1 & 2 & 3 & 4 & 5 & 6 & 7 & 8 & \text { RedGm } & \text { BlkBx } \\ \text { Rises }\end{array}$

3

$\mathrm{G}$

S

$6 \quad G$

$\begin{array}{llll}\mathrm{N} & \mathrm{V} & 1 & \mathrm{G}\end{array}$

$\begin{array}{lllllllllllll}\mathrm{N} & \mathrm{V} & & 1 & 2 & 3 & 4 & & & & & \mathrm{G} \\ \mathrm{N} & & \mathrm{S} & & & & & 5 & 6 & 7 & 8 & \mathrm{G} \\ \mathrm{N} & \mathrm{V} & & & & & 4 & & & & & \mathrm{G} \\ \mathrm{N} & \mathrm{V} & & 1 & 2 & & & & & & & \mathrm{G}\end{array}$

$\begin{array}{lllllll}\mathrm{N} & \mathrm{V} & 1 & 2 & & \mathrm{G} \\ \mathrm{N} & \mathrm{V} & 1 & 2 & 3 & 4 & \mathrm{G}\end{array}$

$\begin{array}{lllll}\mathrm{N} & 3 & \mathrm{G}\end{array}$

$\begin{array}{llllll}\mathrm{N} & \mathrm{V} & 1 & 2 & 3 & \mathrm{G} \\ \mathrm{N} & & 1 & & & \mathrm{G}\end{array}$

$\mathrm{N}-\mathrm{G}$

$\begin{array}{llllllllllll} & \mathrm{V} & & & & & & & & & & \\ \mathrm{N} & \mathrm{V} & \mathrm{S} & 1 & 2 & 3 & 4 & & 8 & \mathrm{G} & \mathrm{B}\end{array}$

$\mathrm{R}$

$\mathrm{N}$

$\mathrm{N}$

$\mathrm{R}$

$\mathrm{R}$

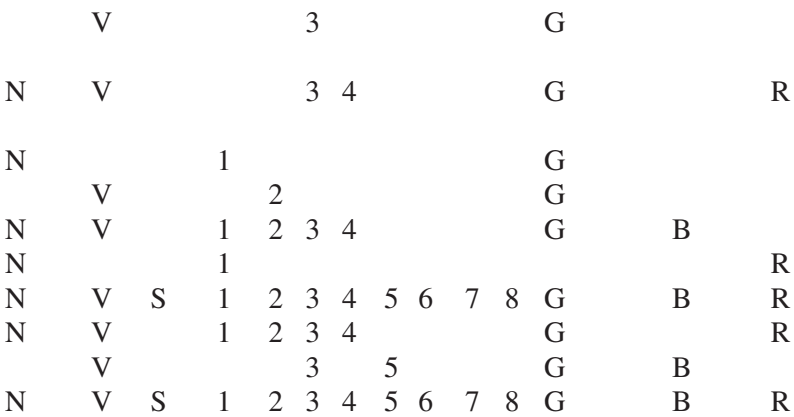

$\begin{array}{lllllllllll}\mathrm{V} & \mathrm{S} & 1 & 2 & 3 & 4 & 5 & 6 & 7 & 8 & \mathrm{G}\end{array}$

B $\quad \mathrm{R}$

$\mathrm{R}$

$\mathrm{N}$

$\mathrm{N}$

$\mathrm{N}$

N

$\mathrm{N}$

$\mathrm{N}$

N

$\mathrm{N}$

N

$\mathrm{N}$

$\mathrm{N}$

$\mathrm{N}$

$\mathrm{N}$

$\mathrm{N}$

$\mathrm{N}$

$\mathrm{N}$

$\begin{array}{lll}1 & 2 & 3\end{array}$

1

$\begin{array}{llll}1 & 2 & 3 & 4\end{array}$

G

V 1

$$
\begin{array}{lll}
\mathrm{V} & 2 & 4
\end{array}
$$

$\begin{array}{lll}\mathrm{V} & 5\end{array}$

$\begin{array}{lllllllll}\mathrm{V} & \mathrm{S} & 1 & 2 & 3 & 4 & 8 & \mathrm{G}\end{array}$

$\begin{array}{llllllllll}\mathrm{V} & \mathrm{S} & 1 & 2 & 3 & 4 & 5 & 7 & 8 & \mathrm{G}\end{array}$

$\begin{array}{llllllll}\mathrm{V} & 1 & 2 & 3 & 4 & \mathrm{G}\end{array}$

$\begin{array}{llllllll}\mathrm{V} & 1 & 2 & 3 & 4 & \mathrm{G}\end{array}$

$\begin{array}{llllllllll}\mathrm{V} & \mathrm{S} & 1 & 3 & 4 & 5 & 6 & 7 & 8 & \mathrm{G}\end{array}$

$\begin{array}{llllllllll} & 1 & 2 & 4 & G & G\end{array}$

$\begin{array}{lllllllllll}\mathrm{V} & \mathrm{S} & 1 & 2 & 3 & 4 & 5 & 6 & 7 & 8 & \mathrm{G}\end{array}$

V 1

$\begin{array}{lllll}\mathrm{V} & 1 & 2 & 3 & 4\end{array}$

V 12

$$
\mathrm{V}
$$$$
\begin{array}{lll}
\mathrm{V} & 3 \\
\mathrm{~V} & 2 & 3
\end{array}
$$

4

$\begin{array}{llll}\mathrm{S} & 4 & 7 & \mathrm{G}\end{array}$

$\begin{array}{lllllllll} & \text { S } & & & & 4 & & 7 & \text { G } \\ \mathrm{V} & \mathrm{S} & & 2 & & 4 & 6 & & \mathrm{G} \\ \mathrm{V} & & 1 & 2 & 3 & 4 & & & \mathrm{G}\end{array}$

R

$$
\begin{aligned}
& \mathrm{R} \\
& \mathrm{R} \\
& \mathrm{R} \\
& \mathrm{R}
\end{aligned}
$$$$
\begin{array}{lllll}
\mathrm{V} & 2 & 4 & 5 & \mathrm{G}
\end{array}
$$

B 


\section{Species}

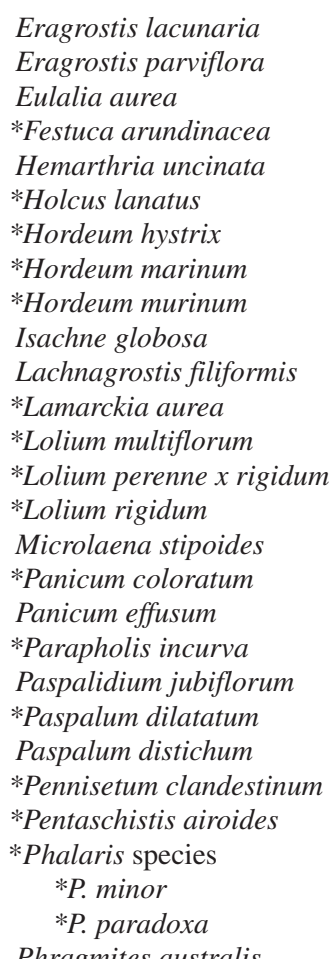

Phragmites australis

*Poa annua

Poa labillardierei

*Poa pratensis

Poa sieberiana

*Polypogon monspeliensis

Pseudoraphis spinescens

*Rostraria cristata

*Rostraria pumila

*Schismus barbatus

* Setaria pumila

Sporobolus mitchellii

*Triticum aestivum

*Vulpia bromoides

*Vulpia myuros

Walwhalleya proluta

Potamogetonaceae

Potamogeton crispus

Potamogeton tricarinatus

Typhaceae

Typha species

T. domingensis

T. orientalis
State River section $\quad$ Vegetation zone

$\begin{array}{lllllllllllll}\text { NSW Vic SA } & 1 & 2 & 3 & 4 & 5 & 6 & 7 & 8 & \text { RedGm } & \text { BlkBx } & \text { Rises }\end{array}$

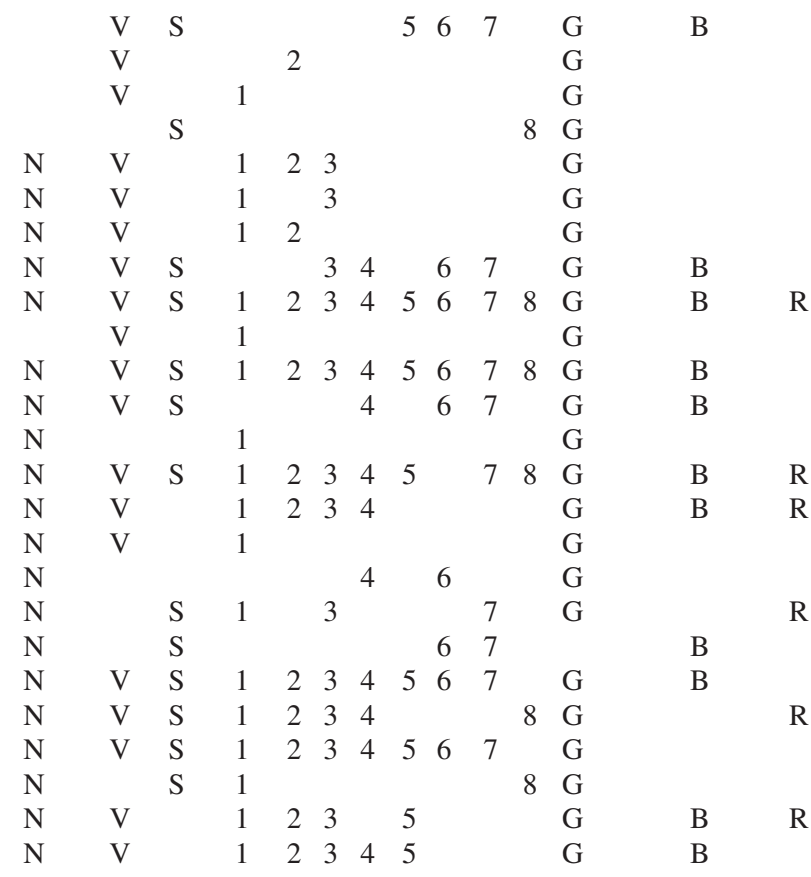

$\begin{array}{lllllllllllllll}\mathrm{N} & \mathrm{V} & \mathrm{S} & 1 & & 3 & 4 & & 6 & 7 & 8 & \mathrm{G} & \mathrm{B} & \\ & \mathrm{V} & \mathrm{S} & 1 & & & & & & 8 & \mathrm{G} & & \\ \mathrm{N} & \mathrm{V} & & 1 & 2 & 3 & 4 & 5 & & & \mathrm{G} & & \mathrm{R} \\ \mathrm{N} & & & 1 & & & & & & & \mathrm{G} & & \\ \mathrm{N} & & & & 2 & 3 & & & & & \mathrm{G} & & \mathrm{R}\end{array}$

$\begin{array}{lllllllllll}\mathrm{N} & \mathrm{V} & \mathrm{S} & 1 & 2 & 4 & 6 & 7 & \mathrm{G} & \mathrm{B}\end{array}$

$\begin{array}{llllllllllll}\mathrm{N} & \mathrm{V} & \mathrm{S} & 1 & 2 & 3 & 4 & 5 & 6 & \mathrm{G}\end{array}$

$\begin{array}{llllllll}\mathrm{N} & \mathrm{V} & \mathrm{S} & 3 & 5 & 7 & \mathrm{G} & \mathrm{B}\end{array}$

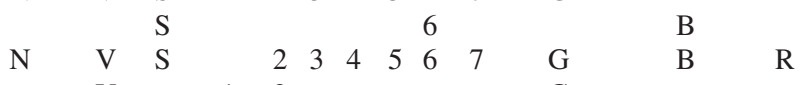

$\begin{array}{llllllllllllll}\mathrm{N} & \mathrm{V} & \mathrm{S} & & 2 & 3 & 4 & 5 & 6 & 7 & \mathrm{G} & \mathrm{B} & \mathrm{R}\end{array}$

$\begin{array}{lllllll}\mathrm{V} & \mathrm{S} & 5 & 6 & 7 & \mathrm{G} & \mathrm{B}\end{array}$

$\begin{array}{llllllllllllll}\mathrm{N} & \mathrm{V} & & 1 & 2 & 3 & 4 & & & \mathrm{G} & \mathrm{G} & \mathrm{R}\end{array}$

$\begin{array}{lllllllllllllll}\mathrm{N} & \mathrm{V} & \mathrm{S} & 1 & 2 & 3 & 4 & 5 & 6 & 7 & 8 & \mathrm{G} & & \mathrm{B} & \mathrm{R}\end{array}$

$\begin{array}{lllllll}\mathrm{N} & \mathrm{V} & 1 & 4 & \mathrm{G}\end{array}$

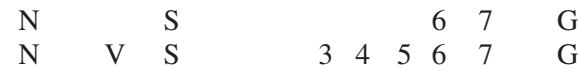

$\begin{array}{llllllllll}\mathrm{N} & \mathrm{V} & \mathrm{S} & 3 & 4 & 6 & 7 & 8 & \mathrm{G} & \mathrm{B}\end{array}$ 
